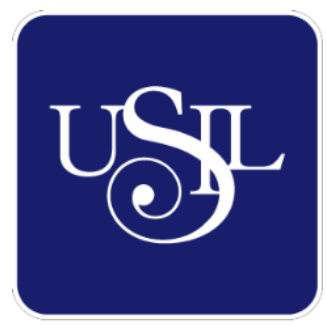

UNIVERSIDAD

SAN IGNACIO

DE LOYOLA

FACULTAD DE HUMANIDADES

Carrera de Arte y Diseño Empresarial

\title{
DISEÑO DE PRODUCTO PARA LA PREVENCIÓN DEL DUELO PATOLÓGICO GENERADO POR LAS NORMAS SANITARIAS EN EL CONTEXTO COVID-19 EN CIUDADANOS DE 40 AÑOS A MÁS EN LIMA METROPOLITANA
}

Tesis para optar el Título Profesional de Licenciado en Arte y Diseño Empresarial

MAILING MIJARU CHANG HUANCAYA

Asesor:

Mg. Rafael Ernesto Vivanco Álvarez

Lima - Perú

2020 


\section{Dedicatoria}

A mi padre, quién en vida fue Jorge Chang Barrera, cuya alegría y más grande anhelo siempre fue verme crecer y superarme cada día más. Gracias.

A mi mejor amiga y madre Luz, por inspirarme a llegar lejos y por darme siempre todo el apoyo que necesito para seguir adelante. Para ella todo mi amor y eterna gratitud por estar siempre en todas las etapas de mi vida.

A María, Naomi y Melina, mis compinches. 


\section{Agradecimientos}

A todas las personas que me ayudaron a hacer más rica esta investigación a través de las entrevistas y encuestas. Gracias por regalarme su tiempo y compartir conmigo sus experiencias y conocimientos.

A mis hermanas y mamá por apoyarme con consejos, ideas y buenas vibras para llevar este proyecto hasta el final.

A Eduardo, por acudir a mi rescate y acompañarme durante mis amanecidas. 
Índice General

Dedicatoria

Agradecimientos

Resumen

Abstract

\section{Capítulo I}

Introducción

Descripción del problema encontrado

Problema principal

Problema secundario

Pregunta de Investigación

Hipótesis

\section{Capítulo II}

Personas de 40 años a mas que sufren de duelo patológico debido a la pérdida de un ser querido causada por el COVID-19

Personas que tuvieron una pérdida durante la pandemia y están en duelo

La familia 
Los amigos

Comunidad

Personal de salud encargado de atender casos de COVID-19

Psicólogos y psiquiatras

Ministerio de Salud del Perú (MINSA)

Equipo Humanitario de Recojo de Cadáveres (EHRC)

Funerarias y crematorios

Seguro Integral de Salud (SIS)

Seguros particulares

Análisis del Campo

Metodología del Problema

Metodología del Proyecto

La muerte

La pérdida 
Desafíos para superar el duelo

Características

Físicas

Emocionales

Cognitivas

Conductuales

Sociales

Espirituales

El Duelo en Tiempo de Coronavirus

Base Legal en el Contexto COVID-19

Directiva Sanitaria No 087-MINSA/2020/DIGESA 
Exagerado

Enmascarado

Inhibido

Silente

Ambiguo

Síntomas de Alarma

Salud mental durante el duelo

Cambios de comportamiento

Factores de Vulnerabilidad

Circunstancias de la muerte

Muerte traumática

Muerte por homicidio

Familiares desaparecidos

Muerte por suicidio

Muerte perinatal

Vínculo con el fallecido

Pérdidas acumuladas

Familia y apoyo social 
Diagnóstico

Estrategia Terapéutica

Psicologica

Psiquiátrica

Indicadores de Recuperación

Diseño de Producto

Diseño y calidad de vida 46

Valores del producto

Productos personalizados

Handmade

Sostenibilidad

Eco-eficiencia

Estrategias generales

Estrategias para la selección y uso del papel 
Cajas de recuerdo

Capítulo IV

53

Público Objetivo

Concepto

Moodboard

55

Paletas de color

56

Tipografías

56

Proyecto de Diseño

57

Relación entre Problema, Público Objetivo y Proyecto

63

Marca del Proyecto

64

Resultado

65

Diseño de la comunicaciòn

65

Piezas empleadas

66

Reflexiones

70

Conclusiones

71

Referencias bibliográficas

72

Anexos

79 
Figura 1. Moodboard del problema

Figura 2. Análisis del concepto

Figura 3. Moodboard del concepto 56

Figura 4. Paleta de color 56

Figura 5. Tipografías 57

Figura 6. Logotipo de la marca 65

Figura 7. Personajes

Figura 8. Caja de producto 67

Figura 9. Linterna de papel 67

Figura 10. Diario de duelo

Figura 11. Diario de duelo interiores 68

Figura 12. Frases interiores del diario 68

Figura 13. Diseño de velas 69

Figura 14. Frasco de dulces 69

Figura 15. Portaretratos

69

Figura 16. Manual de instrucciones

Figura 17. Portada y foto de perfil de Facebook 70 


\section{Resumen}

Actualmente el desarrollo y propagación del virus COVID-19 a nivel mundial, ha generado pánico y desorden en la población. Muchas personas vieron afectada la salud, el trabajo e incluso la libertad con la que vivían día a día; sin embargo, la pérdida más dolorosa ha sido la de aquellos que vieron partir a sus seres queridos a causa del virus, viviendo esta tragedia en medio de mucha confusión y dolor que ha hecho del duelo una experiencia intensa.

Despedir a un ser querido hoy, ha cambiado radicalmente. Las normas sanitarias dictadas por el gobierno con el objetivo de resguardar la salud pública han interferido tanto en el ritual funerario como en la fabricación del proceso de duelo. Es así como surge un conflicto con el desarrollo de este, pues los dolientes no encuentran formas saludables de calmar la pena, encontrándose totalmente vulnerables al desarrollo de un duelo patológico que puede traer consecuencias muy graves para la salud mental de las personas.

Por esta razón se diseñó el proyecto “Abrazo en caja” que tiene el objetivo principal de ayudar a las personas en el duelo, para que logren asimilar su pérdida de forma saludable y así poder retomar sus vidas y elaborar un recuerdo que no les cause dolor, evitando de esta forma que la pérdida se torne patológica. Este consiste en un producto que incluye 7 piezas contenidas en una caja, cada una está pensada para aportar diferentes estímulos durante el proceso de duelo.

Palabras clave: Duelo patológico, COVID-19, salud mental, diseño gráfico. 


\begin{abstract}
Currently, the development and spread of the COVID-19 virus worldwide has generated panic and disorder in the population. Many people were affected by health, work and even freedom to live from day by day. However, the most painful loss has been seeing loved ones die from the virus, living this tragedy with much confusion and pain that has made grief an intense experience.
\end{abstract}

Saying goodbye to a loved one today has radically changed. The sanitary norms dictated by the government, in order to protect the health of the population, have interfered both in the funeral ritual and in the elaboration of the mourning process. This is how a conflict arises with the development of grief, since the mourners do not find healthy ways to calm their pain, being totally vulnerable to the development of a pathological grief that can have very serious consequences on people's mental health.

It is for this reason that the project "Hug in a box" was designed, which has the main objective of helping people in grief, so that they can assimilate their loss in a healthy way and be able to resume their lives and make a memory that does not causes pain, preventing the grief from becoming pathological. This project includes 7 pieces contained in a box, each one is designed to provide different stimuli during the grieving process.

Key words: Prolonged Grief Disorder, COVID-19, mental health, graphic design. 


\section{Capítulo I}

\section{Introducción.}

Hoy en día, el Perú y el mundo entero se encuentran atravesando una emergencia sanitaria importante que está afectando de forma crítica la vida de miles de personas. La presencia del virus SARS-CoV-2 ha significado una pérdida no sólo de salud sino también libertad y salud mental (Moscoso, 2020). Desde esta perspectiva psicosocial, la población, al estar rodeada de tanta enfermedad y muerte, está sufriendo un fuerte impacto a nivel emocional que la hace más vulnerable al desarrollo de trastornos u otras enfermedades psicológicas o psiquiátrica, dificultando la capacidad humana que poseemos para superar las situaciones de crisis (Colegio Oficial de Psicología de Madrid, 2020),

Dentro de las situaciones más difíciles que han acontecido este año, está el no poder cuidar $\mathrm{y}$ atender a un ser querido enfermo durante sus últimos momentos de vida. Este escenario predispone a la familia a sufrir consecuencias negativas durante el duelo, tema que es poco mencionado por su carácter sensible.

Si bien la muerte es algo que siempre ha estado presente, sufrir una pérdida durante la pandemia implica circunstancias para las cuales la población no estaba preparada, es por esto que cuando el virus no cobra una víctima, deja un sobreviviente que debe lidiar con la experiencia de una muerte impensada y con un proceso de duelo difícil.

Cuando se habla del duelo, se hace referencia a un proceso transitorio que sirve para sanar el shock emocional que se vive al experimentar la pérdida de alguna persona u objeto que tuvo un rol significativo en la vida. Esta etapa es inevitable y totalmente normal en el ser humano, cada uno lo vive de forma diferente y se va superando paulatinamente con el paso del tiempo, apoyándose emocionalmente del entorno social para finalmente, aceptar y adaptarse a un nuevo ritmo de vida (Neimeyer, 2002). No obstante, existen excepciones donde las personas no procesan la ausencia de este ser querido prolongando su sufrimiento y deteriorando el estado emocional del individuo (Worden, 1997). 


\section{Descripción del Problema Encontrado.}

Elaborar un proceso de duelo durante la pandemia se ha convertido en uno de los mayores retos para todos aquellos que perdieron a alguien especial, ya que hoy no se tiene la posibilidad de despedir a los seres queridos. Anteriormente, en muchos casos, el evento que marcaba el inicio de duelo era la realización de los ritos funerarios como velorios y entierros, ya que indicaban al doliente que la vida de su ser querido había terminado y además simbolizaba un espacio para recordarlo, para así poder empezar a asimilar la pérdida, y poco a poco ir superándola; sin embargo, debido a la coyuntura actual, el ritual funerario, como se conoce tradicionalmente en el Perú, ha dado un giro abrupto el cual nadie estaba preparado. La nueva normalidad ha exigido cambiar los hábitos y costumbres culturales para poder resguardar la salud propia y la de la sociedad (Pinasco, 2020). Hoy, se deben respetar los protocolos establecidos para el manejo y disposición de cadáveres posiblemente infectados con el virus, los cuales generan en los dolientes dilemas y conflictos en torno a sus valores, creencias y concepto de tener una muerte digna. Al tener que atravesar el inmenso dolor que trae consigo el perder a un ser querido y además perder esa oportunidad de consuelo que muchas veces se encuentra cuando se acompaña al cadáver y se le brinda un pequeño gesto de afecto, acompañamiento y cuidado. Los dolientes sufren de grandes factores estresores que aterrizan en un sentimiento de culpa que afecta directamente su proceso de duelo, haciéndolo más complicado y difícil de superar aumentando el riesgo de que desarrollen un duelo patológico (Herrera, 2020). El duelo patológico, en este contexto, es causado por diversos factores externos. Entre ellos encontramos el no poder despedirse del fallecido por tener que respetar la distancia física que demandan las medidas sanitarias, las restricciones en el ritual funerario común, que incluyen la cantidad de asistentes, las medidas de protección obligatorias y la incapacidad para realizar un entierro normal, el no poder reunirse con familiares y amigos cercanos impidiéndoles poder tener el apoyo interpersonal que se necesita durante el duelo, despertando una sensación de soledad y tristeza que solo se puede expresar a distancia a 
través de la frialdad de los teléfonos o las videollamadas, y por último, el pensamiento constante de que aquel ser querido murió solo, sin haberse podido despedir de nadie (Poudevida y Castillo, 2020).

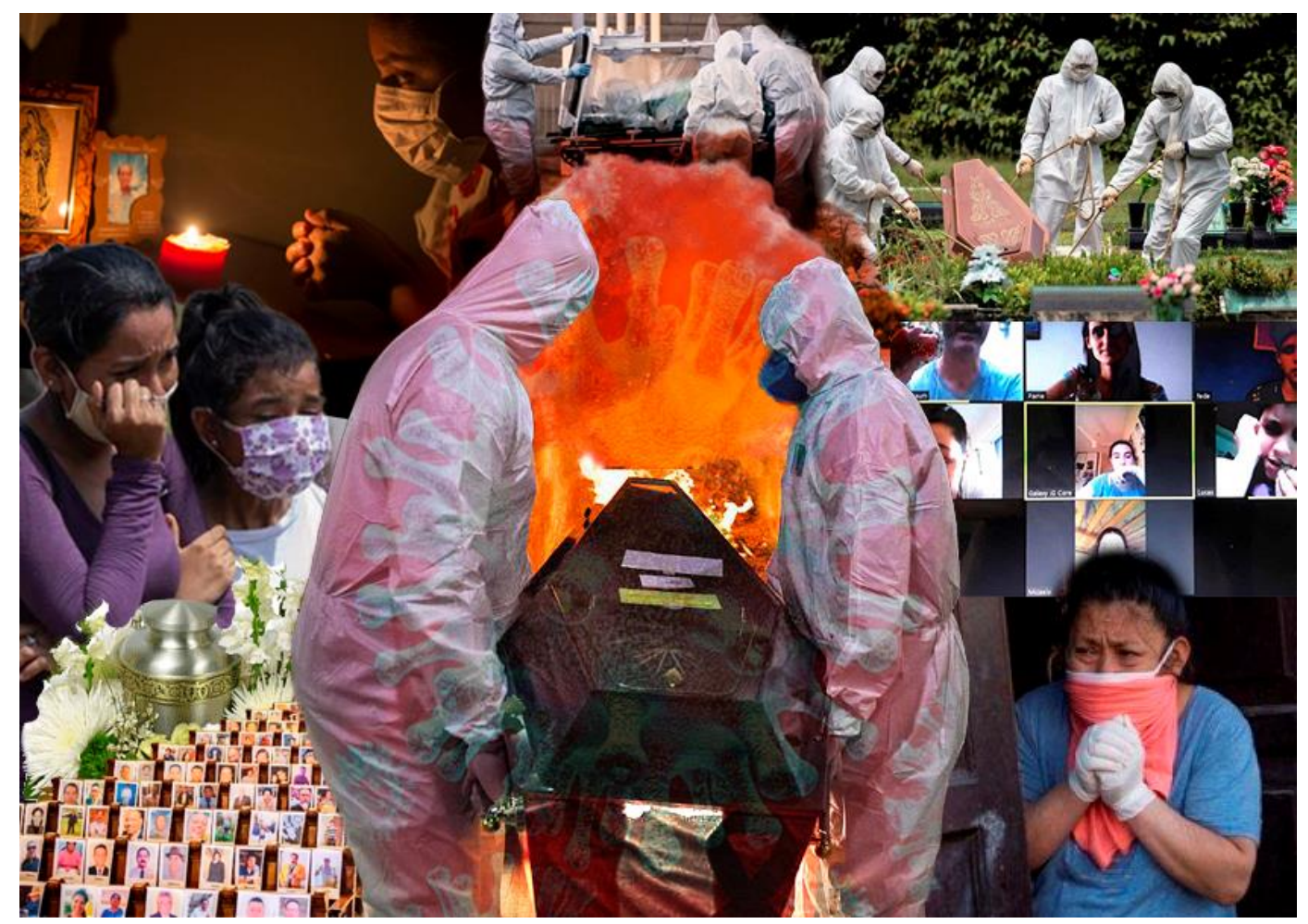

Figura 1 Moodboard del problema. Fuente propia

\section{Problema principal.}

El duelo patológico generado por las normas sanitarias en el contexto COVID-19 en los ciudadanos de 40 años a más de Lima Metropolitana.

\section{Problemas secundarios.}

Trastorno depresivo mayor causado por el duelo patológico generado por las normas sanitarias en el contexto COVID-19 en los ciudadanos de 40 años a más de Lima Metropolitana.

Cambios de comportamiento causados por el duelo patológico generado por las normas sanitarias en el contexto COVID-19 en los ciudadanos de 40 años a más de Lima Metropolitana. 


\section{Justificación de la Investigación.}

El Perú es hoy el país con más víctimas mortales de COVID-19 registrados en el mundo, llegando a registrar 28,000 fallecidos a causa del virus, registrando 85.8 muertes por cada 100,000 habitantes (Gestión, 2020). La pandemia trajo consigo muchos cambios en el estilo de vida, pasando por estados de emergencia, distanciamiento social, confinamiento y protocolos sanitarios estrictos para poder evitar la propagación del virus en los distintos hogares y comunidades. Sin embargo, cuando se trata de aquellos que desafortunadamente se encuentran en duelo por la pérdida de un ser querido se evidencia un problema de salud mental.

La muerte en estos tiempos se ha convertido en un tema complicado de sobrellevar. El estrés, confusión, culpa y pena se intensifican al no poder realizar los rituales propios de la cultura, complicando el proceso de duelo, el cual está relacionado directamente con el estado psicológico de las personas y cuando se convierte en un caso de duelo patológico empieza a degenerar la salud mental del doliente, imposibilitando el retorno a una rutina de vida normal y saludable (Herrera, 2020).

Es importante poder abordar este tema durante la situación actual; ya que, conociendo más al respecto, se puede encontrar información importante que permita saber cómo es el proceso de duelo y qué tanto o en qué momento los nuevos protocolos sanitarios están perturbando la salud mental de los dolientes haciendo imposible la asimilación de la pérdida. De esta forma, gracias a esta investigación se podrán establecer recomendaciones y soluciones creativas que, a través del diseño gráfico, puedan lograr que todas estas personas que atraviesan un momento amargo puedan llegar a aceptar la pérdida y posteriormente superar el duelo, llegando finalmente a alcanzar el bienestar emocional. 
Pregunta de Investigación.

¿Cómo el diseño de producto para sobrellevar el duelo contribuye a la prevención del duelo patológico generado por las normas sanitarias en el contexto COVID-19 en ciudadanos de 40 años a más en Lima Metropolitana?

\section{Hipótesis.}

El diseño de producto para sobrellevar el duelo contribuye a la prevención del duelo patológico generado por las normas sanitarias en el contexto COVID-19 en ciudadanos de 40 años a más en Lima Metropolitana. 


\section{Capítulo II}

\section{Análisis de los Actores.}

\section{Personas de 40 años a más que sufren de duelo patológico debido a la pérdida de un ser querido causada por el COVID-19.}

Es el actor principal del problema y comprende a toda persona a partir de los 40 años cuyo familiar murió víctima del COVID-19 durante los primeros meses de la pandemia y, hasta el día de hoy viven el duelo de manera intensa, llegando a desarrollar una característica patológica. Esto se debe a que estas personas han tenido que realizar todo el proceso post mortem cumpliendo de manera obligatoria con todas las regulaciones sanitarias dictadas por el gobierno para prevenir el contagio de la enfermedad.

\section{Personas que tuvieron una pérdida durante la pandemia y están en duelo.}

Este actor es toda persona que ha enfrentado una pérdida, por alguna otra causa, e igual que el actor anterior ha tenido que acatar las normas sanitarias al momento de manejar los restos de su ser querido. La diferencia entre ambos es que este actor aún se encuentra atravesando un proceso de duelo normal, y este puede resultar de dos maneras a futuro. La primera es que esta persona resuelva sanamente el duelo y siga con su vida normal, mientras que la segunda es que desarrolle una patología en el duelo debido al shock provocado por las nuevas circunstancias sanitarias.

\section{La familia.}

El fallecimiento de una persona altera el equilibrio de cualquier sistema familiar y en este caso no es la excepción. Toda familia en esta situación se encuentra ante el nuevo reto de reorganizarse y adaptarse a un nuevo estilo de vida, pues todos viven el proceso de duelo independientemente en distintos niveles. El papel de la familia es muy importante entre los mismos miembros ya que, al encontrarse en un mismo entorno, influyen en las reacciones y el estado de ánimo del otro, lo cual puede ser favorable o desfavorable en la superación de este proceso dependiendo del tipo de actitud y comportamiento que asuma cada integrante (Yi, 2015). Por otro lado, la familia podría impedir el desarrollo de un duelo 
normal cuando uno o varios de sus elementos también han tenido la mala suerte de contagiarse del virus y presentan síntomas de la enfermedad.

\section{La pareja.}

En este contexto la pareja es un actor que podría verse afectado en menor grado por la pérdida. Estas personas son las que suelen prestar especial atención al estado y cuidado personal del doliente en estos casos donde la familia también atraviesa por la misma experiencia. Generalmente la pareja tiene mayor posibilidad de comunicación con el doliente y su papel como estímulo positivo es tener un rol pasivo, discreto y estar disponible para cuando el doliente necesite atención de cualquier tipo (Yi, 2015). Este apoyo en estos casos es bastante positivo ya que debido a la coyuntura el distanciamiento social obligatorio impide que los dolientes puedan recibir estímulos de terceras personas.

\section{Los amigos.}

Son personas de confianza que rodean al doliente, generalmente muestran mucha empatía con ellos durante el proceso de duelo. Anteriormente estas personas eran asistentes a los rituales funerarios, visitaban o acompañaban a los dolientes para reconfortarnos emocionalmente (Yi, 2015). Hoy en día, este tipo de estímulo ha cambiado y se manifiesta a distancia a través de llamadas telefónicas, videollamadas o mensajes en redes sociales. Si bien es cierto, estos canales no terminan de sustituir el contacto físico; sin embargo, pueden ser positivos si son bien recibidos por los dolientes (Alarcón et al, 2020).

\section{Comunidad.}

La comunidad juega un papel importante hoy en día; ya que la nueva convivencia se da aquí. Debido al aumento de cifras de contagio y muertes por COVID-19, el miedo, rechazo, evasión e incluso actos de discriminación en varias comunidades por parte de los vecinos hacia los residentes de los hogares donde vivián víctimas mortales del virus afecta el duelo de estas personas (Centros para el Control y la Prevención de Enfermedades, 2020). 


\section{Personal de salud encargado de atender casos de COVID-19}

Estas personas comprenden un grupo de médicos, personal de enfermería o trabajadores sociales quienes atienden todos los ingresos de posibles casos de COVID-19 a los establecimientos de salud tanto públicos como privados. Ellos son quienes generalmente dan la noticia de la defunción del paciente a sus familiares a través de llamadas o mensajes de texto. Muchas veces se critica en ellos la frialdad y falta de sensibilidad con la que manejan la comunicación no solo de la defunción sino también del tratamiento de los pacientes.

\section{Psicólogos y psiquiatras}

Ambos profesionales de la salud mental se encargan de brindar soporte emocional a casos de duelo que presentan complicaciones y se convierten en una patología. Los más inmediatos son los psicólogos, quienes ofrecen a los dolientes una serie de terapias en donde identifican qué pasos del proceso de duelo están pendientes o no se han superado y ayudan a las personas a afrontarlos para que puedan superar el duelo y retomar su vida con normalidad. Por otro lado, el psiquiatra, es el que toma las riendas del tratamiento en caso las sesiones psicológicas hayan fallado. Este pone en práctica un tipo de psicoterapia orientada al tratamiento de este mal similar a las técnicas utilizadas para la depresión y para el trastorno de estrés postraumático. Además, puede acondicionar medicamentos a la par del tratamiento (Yi, 2015). Hoy en día, como muchos otros servicios, estos profesionales también trabajan con sus pacientes a distancia, por vía telefónica u online.

\section{Ministerio de Salud del Perú (MINSA)}

El Ministerio de Salud del Perú se encarga de que cada ciudadano peruano tenga acceso a un servicio de salud integral y efectivo. Además, promueve la prevención de enfermedades. Es por esto que, ante la presencia del virus en nuestro país, el MINSA, junto con otros órganos del Estado, planteó y dictó todas las medidas que deben tomarse para prevenir el contagio. Entre ellas ubicamos aquellas que se deben cumplir ocurrida la muerte de una persona con sospecha o diagnóstico positivo para COVID-19 que prohíben 
todo tipo de contacto con el cadáver y cualquier reunión social. Generando un conflicto con las costumbres y tradiciones practicadas antes de la pandemia y negando una despedida digna a los seres queridos.

\section{Equipo Humanitario de Recojo de Cadáveres (EHRC)}

Es el equipo organizado por el MINSA que se encarga de manejar los restos de las personas fallecidas por COVID ya sea en una vía pública, vivienda u otro lugar. Este equipo está conformado por un médico cirujano, un profesional en salud ambiental, un chofer y personal de apoyo. Actúan dentro de las 24 horas posteriores a la muerte y coordina junto con el SIS o el seguro particular con el que cuente el fallecido el retiro del cadáver. Posteriormente proceden a realizar con los mismos la cremación o sepultura según disponga algún familiar directo (MINSA, 2020).

\section{Funerarias y crematorios}

Se encargan de realizar inhumaciones y crematorios respectivamente, no solo de víctimas de COVID-19 sino también del resto de casos. Este servicio, también debe respetar los protocolos necesarios para garantizar la salud de las familias y de su personal. Muchas de ellas afirman no haber estado preparadas para atender la gran demanda diaria y haber tenido que reinventarse ante la coyuntura (RPP Noticias, 2020).

\section{Seguro Integral de Salud (SIS)}

El SIS es un organismo que brinda aseguramiento público en salud, especialmente a las poblaciones vulnerables. En el contexto de la pandemia, este sistema ha ofrecido una cobertura económica gratuita por infección de COVID-19, que incluye gastos de hospitalización y gastos de muerte (Plataforma Digital Única del Estado, 2020).

\section{Seguros particulares}

Los distintos seguros particulares en el Perú han confirmado que la atención médica producto del brote de COVID-19 está garantizada, cumpliendo con los protocolos establecidos por el MINSA. Varias empresas aseguradoras como Rímac, La positiva, Pacífico y Mapfre, ofrecen un plan de cobertura al 100\% a casos de COVID-19; sin 
embargo, cada empresa maneja sus propios términos y condiciones en cuanto a atención y financiamiento. Hasta la fecha se ha podido detectar que los precios de los seguros se han elevado durante la pandemia (Salud con Lupa, 2020).

\section{Análisis del Campo.}

Tanto el duelo normal como el duelo patológico son procesos personales que se desarrollan a nivel psicológico. Es por esto que los actores principales están más propensos a desarrollar los síntomas del duelo cuando tienen un tiempo a solas para pensar en la pérdida y expresar dolor, sentimientos o pensamientos hacia su ser querido. Este momento casi siempre se da en los hogares de los dolientes, ya que aquí tienen privacidad y, muchas veces, personas de las cuales apoyarse, aunque naturalmente siempre existe la tendencia al aislamiento. El hogar será entonces el campo de proceso de duelo; sin embargo, siempre se podrá considerar otros espacios de uso cotidiano del doliente, como su lugar de trabajo (si lo tuviera) o el transporte público o privado.

En cuanto a las variaciones de campo, estas se dan en los diferentes momentos del día (mañana, tarde, noche) ya que, se pensó comprobar si existe alguna diferencia en el comportamiento de la persona en duelo o si por el contrario es regular durante todo el día. Por último, también se pueden observar y estudiar distintos casos, testimonios e historias de familiares de víctimas del COVID-19 en el área de Lima Metropolitana a través de distintos canales nacionales de televisión y en redes sociales como Facebook.

\section{Metodología del Problema.}

El presente estudio se elaboró gracias a la revisión e interpretación de diferentes fuentes bibliográficas recopiladas de bases de datos, libros y artículos electrónicos relacionados con psicología, medicina, salud mental y otros temas afines al duelo patológico. Por otro lado, se hizo uso de otras herramientas como entrevistas semiestructuradas vía telefónica dirigidas a personas de 40 años a más que hayan sufrido una pérdida durante la pandemia y sus familias para poder conocer con mayor detalle la experiencia vivida, cuál fue su pérdida y cómo se dio el proceso fúnebre, qué relación tenía con esta persona, cómo se 
sintió en ese momento, qué efectos provocó en su vida diaria, cuál fue el impacto familiar y cómo está intentando superarlo. Estas entrevistas fueron netamente de índole emocional. Además, también se realizó una entrevista semiestructurada vía Zoom a Tatiana Dunezat Urbina, especialista en psicología, con el objetivo de recopilar información acerca de cómo influyen los ritos funerarios o creencias de las personas en la resolución del duelo y cómo la omisión de estos procesos y vivir en la nueva normalidad pueden generar un caso de duelo patológico.

Por último, se realizaron entrevistas a personas mayores de 40 años sin ninguna característica en particular con el fin de conocer cómo se siente ante la coyuntura, si tiene temor, angustia o miedo de contagiarse o que algún miembro de su familia lo haga, qué es lo que más le preocupa y cuál sería su mayor reto si tuviese que experimentar la muerte de un ser querido en pandemia. Con este mismo objetivo se realizó una encuesta virtual a través de la herramienta Formularios de Google a personas mayores de 35 años que vivan en el área de Lima Metropolitana.

Adicionalmente, se realizó un seguimiento a los entrevistados durante dos semanas los días lunes, jueves y sábado a través de llamadas telefónicas y mensajes a través de redes sociales para poder identificar conductas, emociones, formas de expresión, cuánto tiempo durante el día se mantiene pensando en la pérdida, si existe aislamiento o no, su nivel de interacción con el resto de personas en el hogar, vecinos u otras terceras personas, si acepta llamadas o interacción virtual o no, si continúa asistiendo a su trabajo (o teletrabajo), si continúa o abandona sus responsabilidades en el hogar, y de esta manera ver si se realizaron cambios en el proceso de duelo o no.

\section{Metodología del Proyecto.}

Gracias a la recopilación y análisis de todas las herramientas de investigación para recabar información para el siguiente trabajo, se pudieron encontrar los datos necesarios para empezar a estructurar un proyecto que aporte una solución desde la disciplina del diseño gráfico. 
Este proceso empezó con una evaluación de los actores involucrados con el problema, para así poder elegir a uno de ellos y convertirlo en el público objetivo del proyecto. Seguidamente se realizó un análisis a profundidad de las características del actor elegido para poder determinar el mensaje que se quiere comunicar, el tipo de comunicación que se establecerá y los canales por los cuales se llegará a ellos, todo esto con el objetivo de incentivar el desarrollo de un duelo sano y así prevenir el duelo patológico.

Una vez establecido el mensaje, se realizó el planteamiento del concepto del proyecto que surgió del análisis de una lluvia de ideas en torno al duelo y al duelo patológico.

Establecido el concepto, se planteó en qué consistiría el proyecto y se llegó a la conclusión de realizar un producto de ayuda para sobrellevar el duelo. Luego se hizo la articulación del proyecto empezando por el planteamiento de los posibles ítems que pueda incluir este producto, con la ayuda de las psicólogas Tatiana Dunezat, quien fue pieza clave para corroborar que todos sus elementos sean estímulos positivos para la resolución del duelo. Después, se revisaron materiales y técnicas dentro del diseño de producto y de empaque y se dio inicio al proceso de diseño de las piezas y el empaque.

Como etapa final, se realizó una campaña en redes sociales para presentar el producto y darlo a conocer al público y pueda empezar a ser distribuido en el área de Lima Metropolitana, con miras a que en futuro pueda llegar a otras regiones del Perú. 


\section{Capítulo III}

\section{La Muerte.}

Es imposible tratar el tema del duelo sin antes hablar sobre la muerte. Existen tantos significados de muerte como personas en el mundo, y este concepto dependerá de las vivencias, creencias y valores. Es cuando suceden las pérdidas, las enfermedades, el fallecimiento y la experiencia del duelo que las personas pueden acercarse a la muerte. Desde la medicina, la ciencia deshumaniza a los pacientes, pasando a ser solo un objeto más. Cuando estos reciben tratamiento, la visión médica es mantener bajo cualquier circunstancia los signos vitales; sin embargo, el tacto, sensibilidad y habilidad para asimilar con interés los sentimientos y necesidades de las personas que sufren o están próximas a la muerte son casi nulas. Muchos pacientes no necesitan recibir respuestas rígidas o científicas, sino un trato empático y comprensivo durante la enfermedad. Para esta ciencia la muerte tiene un significado negativo, pero no de una forma humana; sino como un fracaso profesional (Kubler-Ross, 1975).

Desde el punto de vista religioso siempre se ha tratado de conseguir una respuesta a los misterios de la muerte y lo que hay más allá de ella (Yoffe, 2006). Según Koening (1994) citado por Yoffe, para muchos, la religión es un refugio y alivio ante los problemas físicos y mentales, y herramientas como la oración o el rezo tienen efectos sanadores y de perdón para gozar el paraíso de la vida después de la muerte.

Para la psicología, perder es una parte inevitable de la vida humana y existe una disciplina orientada al estudio de la vida, la muerte y el proceso entre ambas, denominada Tanatología. La muerte en el mundo occidental contemporáneo es considerada una de las experiencias más traumáticas que los vivos pueden experimentar. Cuando alguien sufre una pérdida o contempla la muerte de otra persona, el proceso que vivirá desde ese momento en adelante se desarrollará a nivel psicológico y traerá consigo cambios notorios en el estilo de vida del individuo (Vargas, 2007). 


\section{La Pérdida}

A lo largo de la vida, todas las personas sufren pérdidas, ya sean significativas o pasajeras. Estas pueden ser simbólicas o físicas (Rando, 1993) y se pueden manifestar de distintas maneras; por ejemplo, a través de una separación sentimental, un divorcio, el fallecimiento de una persona cercana, un cambio de residencia, ser despedido del trabajo o perder algún objeto especial. Por ende, la pérdida simboliza la falta de una persona, objeto, situación o estado con el cual se tenía un lazo emocional y dependiendo de la magnitud del apego, mayor o menor será la intensidad del trauma que provoque cuando ya no esté presente en la vida del individuo (Cassem, 1975).

Cada persona maneja la muerte de manera distinta. Mientras el ser humano va creciendo, va viviendo pérdida tras pérdida y para cuando llega a la edad adulta las maneja de acuerdo a cómo ha enfrentado las previas, desarrollando así su propio mecanismo de reacción (Frantz, 1984). Vivirlas es importante pues ayuda a elaborar un proceso de duelo propio y así lograr adaptarse al cambio sin toparse con muchos desafíos que, en ocasiones, pueden volverse complicados.

\section{EI Ritual Funerario Antes y Después del COVID-19.}

La elaboración del duelo va más allá de la reconstrucción personal e interpersonal del doliente, ya que también comprende una dimensión social que se debe elaborar dentro de la comunidad. Las culturas alrededor del mundo, por más antiguas o modernas que sean, han desarrollado sus propios rituales funerarios para contemplar la defunción de alguno de sus miembros. Estas ceremonias existen para fortalecer los lazos entre los que quedan vivos y honrar a la persona que ya no está (Neimeyer, 2002).

Sin embargo, hoy en día este ritual ha cambiado completamente. Los dolientes entran en conflicto al momento de decidir de qué manera se llevará a cabo la despedida de sus seres queridos al tener que anteponer la seguridad de los demás. Las medidas establecidas por el MINSA indican que toda persona fallecida por COVID-19, debe ser cremada o sepultada respetando el protocolo establecido para evitar la propagación del virus; sin embargo, en 
culturas como la que existe en Perú, en donde no existe la costumbre de cremar un cuerpo fallecido, sino que por el contrario, se da inicio al luto con una despedida física del cuerpo, se extiende el riesgo a generarse un duelo patológico (Herrera, 2020).

\section{El Duelo Normal.}

El duelo es el estado mental natural más estresante al que se pueden enfrentar los seres humanos (Worden, 1997) y consiste en un proceso individual de aflicción que al mismo tiempo sugiere un reto que puede representar una oportunidad para crecer y evolucionar superando la crisis personal (Yi, 2015).

El duelo, en el contexto cultural occidental, se refiere al "conjunto de procesos psicológicos y psicosociales que siguen a la pérdida de una persona con la que el sujeto en duelo (...) estaba psicosocialmente vinculado" (Cabodevilla, 2007, p.165). Normalmente, el proceso de duelo va evolucionando meses posteriores a la pérdida dependiendo de la persona. Durante este periodo no se suele considerar necesaria la guía profesional, pues el doliente ya dispone de los recursos necesarios para afrontar la pérdida por sí solo y tiene un entorno social sólido que respalda y acompaña un proceso de duelo normal (Agnew et al, 2010).

\section{El duelo en personas adultas.}

Durante la adultez las personas concentran su energía en el cumplimiento de sus responsabilidades (Gamo y Pazos, 2009) y conciben la idea de la muerte como algo que ocurrirá en algún momento tanto para ellos como para sus seres queridos. Llegada la adultez tardía, pasados los 40 años, el mismo cambio físico y desgaste psicológico que conlleva el envejecimiento los hace replantear su estilo de vida y su visión del futuro para bien o para mal. Muchos adultos le tienen miedo a la muerte porque esto significa algo totalmente desconocido, no saber qué pasará después, si esta será dolorosa, la descomposición de la carne y la tristeza que podrían generar en sus seres queridos es algo inquietante para ellos (Lafuente, 1996). 


\section{Diferencias de género en el duelo.}

Así como en muchos otros temas, el duelo se vive de forma distinta dependiendo del género. Las mujeres han sido el foco principal en estudios relacionados al duelo debido a que ellas presentan mayor intensidad al expresar sus emociones a diferencia de los varones, quienes tienden a llevar el duelo de forma más racional o manteniendo ocupada la mente con otros aspectos relacionados a la pérdida como los trámites con la compañía de seguros o la preparación del velatorio (Neimeyer, 2002). Las mujeres que atraviesan la crisis del duelo suelen exteriorizar sus sentimientos y así buscar y recibir naturalmente consejo o apoyo, mientras que los hombres se mantienen más serenos y reprimen sus emociones para demostrar fortaleza ante los ojos de los demás.

\section{El papel de la familia}

Este es un sistema que se mantiene equilibrado gracias a cada miembro del hogar; cuando uno de ellos fallece desaparece esa armonía y se convierte en incertidumbre. A pesar de que el duelo es un proceso personal, todos los elementos de la familia se influencian unos a otros durante el duelo, ya que cada uno tuvo una relación emocional independiente con el fallecido. Esta razón también indicaría por qué a algunos miembros les afecta más que a otros (Yi, 2015).

Cuando las familias son adaptativas con límites flexibles, acepta sentimientos positivos y negativos, crea una relación de intimidad entre sus elementos, comparte las sensaciones de malestar, pero también da consuelo y cuidados mutuos y será flexibles con sus roles según sus necesidades (Pérez, 1999). Por el contrario, dentro de los modelos familiares desadaptativos, están las familias inflexibles. Estas insisten que todo el sistema se mantenga como si nada hubiese pasado, los roles no cambian para que nadie tome el lugar del difunto; sin embargo, sin querer se establecen roles equivocados como que el hijo o hija mayor asuma el rol de papá o mamá. Además, en estas familias siempre se observa una dependencia marcada a los ritos religiosos y otras expresiones culturales. 
Por su parte, las familias distorsionadas, son aquellas que idealizan al difunto, rechazando cualquier expresión de sentimientos negativos hacia él. Para este sistema es necesario mantener al difunto presente a su alrededor dejando sus pertenencias tal y como este las haya dejado. Aquí el sentimiento que siempre es latente es la culpa. También existen familias con límites porosos, para quienes es muy difícil aceptar las diferencias entre los duelos de sus miembros, son muy intolerantes y generan un ambiente hostil y complejo (Pérez, 1999).

\section{Etapas del duelo.}

Para atravesar el duelo se necesitan dos elementos: Paciencia y decisión. Esta experiencia toma su propio tiempo y no se puede obviar ni acelerar su proceso; por ende, no hay un tiempo fijo en el que sea obligatorio resolverlo (Díaz et al, 2014).

Hay muchos autores que tienen su propia propuesta sobre el proceso de duelo y gracias a Schiaffino (2014) podemos conocer las más acertadas sintetizadas de la siguiente manera. Para Linderman (1944) la primera etapa es choque e incredulidad; la segunda etapa, aceptación de la pérdida; la tercera etapa, resolución del duelo y reorganización del estilo de vida. En cambio para O’Connor (1969) la primera etapa es quiebre de hábitos antiguos (desde el fallecimiento hasta la semana 8 posterior a la pérdida); la segunda etapa, replanteamiento del estilo de vida (desde la semana 8 hasta el año posterior a la pérdida); la tercera etapa, búsqueda de nuevas metas (del año hasta los dos años) y la cuarta etapa, reajuste (pasados los dos años). En el caso de Worden (1982) la primera etapa es la aceptación de la pérdida; la segunda etapa, la experimentación de dolor y pena; la tercera etapa, la adaptación a una nueva vida sin el fallecido y la cuarta etapa, eliminar toda energía emocional puesta en el fallecido y enfocarla en otras relaciones sociales. Por otro lado, para Neimeyer (2000) la primera etapa comprende evitación, incredulidad e impacto; la segunda etapa, aceptación y reconstrucción y la tercera etapa, adaptación. Por último para Fonnegra (2001) la primera etapa es de evitación e impacto, aturdimiento y anestesia 
emocional; la segunda etapa, es para enfrentar la pérdida y la tercera etapa es para el restablecimiento, reorganización y vuelta a la vida.

\section{Desafios para superar el duelo.}

Autores como Worden y Rando citados por Neimeyer (2002), afirman que cada persona que vive el duelo debe enfrentar una serie de retos con el objetivo de sobreponerse a la pérdida. Estos retos no son parte de un proceso lineal, y no es necesario superarlos por completo, lo que realmente se busca con esto es poder rescatar las lecciones que ayuden a mantener un estado de ánimo regular tanto a los meses de la pérdida como a los años de esta. Las pérdidas importantes vuelven a la mente de las personas inclusive después de muchos años por eso es sumamente útil cumplir con esta tarea para elaborar el duelo de manera saludable.

Primero, reconocer la pérdida. Por mucho que este paso pueda parecer obvio, es uno de los más difíciles de superar pues la ausencia de esta persona es difícil de sobrellevar.

Asimismo, este reto implica poder reconocer la pérdida dentro del sistema familiar y qué tanto cambiará la vida que solía ser cotidiana.

Segundo, aprender a manifestar el dolor y sentimientos. Las personas deben saber identificar sus sentimientos, ordenarlos y poder vivirlos a través de momentos de reflexión personal o en momentos de interacción con otras personas.

Tercero, ordenar el significado de las cosas. El impacto de sufrir una pérdida puede cambiar la manera en la que vemos el mundo. Por ejemplo, si se vive la pérdida de un niño pequeño podría verse alterado el concepto de justicia o cuestionar la existencia de un Dios. Es así como la pérdida puede cambiar la conducta, valores y creencias determinando una nueva perspectiva de lo que vendrá más adelante.

Cuarto, adaptarse y reinventarse. Es importante no olvidar ni censurar la pérdida sino que se debe mantener el vínculo a través de un recuerdo que permita a las personas encontrar un efecto tranquilizante en vez de uno de tristeza. Cuando se experimenta una pérdida da la impresión de que con ella se va una parte de la vida y las personas tienden a sentirse 
vacías. Para esto se suele fijar un rumbo nuevo con otras prioridades por delante para volver a retomar el control y el sentido, adaptándose a una nueva etapa.

\section{Características.}

Físicas. Las manifestaciones físicas del duelo se dan como sensaciones corporales, como boca seca, debilidad muscular, vacío en el estómago, presión en el pecho o en la garganta, falta de aire y energía, hipersensibilidad al ruido y sentirse fuera de sí (Worden, 1997).

Emocionales. La mayor parte del duelo se desarrolla a nivel emocional y se manifiestan sentimientos comunes como tristeza, que suele mostrarse a través del llanto; enfado, con el que se vive una sensación de resentimiento y frustración; culpa, con ella existe arrepentimiento por no haber hecho lo suficiente, no haber tratado de cierta forma o no haberle dicho algo a la persona cuando vivía; ansiedad, que se puede manifestar a través de pequeñas inseguridades como también con ataques de pánico; soledad, en caso de haber vivido con el fallecido; fatiga, expresada a través de la indiferencia; impotencia, presente en las primeras fases del duelo; shock, en caso de muertes repentinas; anhelo, observado especialmente en mujeres viudas y alivio, en caso el fallecido haya muerto después de haber estado lidiando con una enfermedad oncológica o crónica. En contraste, se puede apreciar casos donde no se observa ninguna emoción, esta insensibilidad se da por no querer lidiar con todos los sentimientos previos como una medida de protección (Worden, 1997).

Cognitivas. Hacen referencia al estado mental del doliente que desencadena ciertas dificultades como falta de concentración, olvido de las cosas, ideas repetitivas, etc. (Ayarra et al, 2005). En las primeras etapas del duelo hay pensamientos que invaden la mente de los dolientes, pero no de forma permanente. Entre ellos encontramos incredulidad, confusión, preocupación, sentido de presencia y alucinaciones. Este estado mental se transforma en tristeza y ansiedad que puede manifestarse de manera intensa; sin embargo, esto es totalmente normal si desaparece con el tiempo (Worden, 1997).

Conductuales. Algunas conductas que se observan durante el duelo son: Trastornos del sueño, problemas para dormir o para despertar, muchas veces estos trastornos son un reflejo 
de miedo a soñar, a no volver a despertar o a la soledad en la cama o en la habitación. Trastornos alimenticios, comer mucho o comer muy poco. Facilidad para distraerse, no prestar atención a sus acciones ni actitudes. Aislamiento, tienden a separarse de las personas a su alrededor y a perder interés por lo que esté pasando afuera. Soñar con la persona muerta, pueden ser sueños normales o pesadillas angustiantes y son útiles para los especialistas para poder analizar el desarrollo del duelo. Llamar y buscar a la persona fallecida. Suspirar, reacción que ocurre debido a las complicaciones físicas causadas por la dificultad para respirar. Llorar, se cree que, gracias a las lágrimas producidas por el estrés emocional, a diferencia de aquellas segregadas naturalmente por la irritación ocular, el organismo elimina sustancias tóxicas que regulan la homeostasis (Frey, 1980). Visitar lugares o atesorar objetos del fallecido, simboliza miedo a olvidar (Worden,1997).

Sociales. A nivel social la persona manifiesta un rechazo a las personas y se aísla de su grupo social, también puede manifestar resentimiento hacia estas personas (Ayarra et al, 2005).

Espirituales. La religión y la fe son un refugio para las personas creyentes; ya que una de las principales promesas que hace la religión es la posibilidad de volver a estar junto a los muertos en una especie de paraíso. Las personas que se apoyan en esto suelen sentirse más ligeras y tranquilas al creer que aquel ser querido realmente no murió, sino que pasó a mejor vida. No obstante, varios de los conceptos abstractos de la religión podrían chocar con la resolución del duelo, ya que desde un inicio la religión niega la muerte para decir que se vive de forma espiritual y, como ocurre en el caso de la religión católica, ofrece una promesa de resurrección. Una persona en duelo puede aferrarse fuertemente a una falsa esperanza de que escucha, ve o siente al fallecido a su lado en espíritu, este es un síntoma normal durante el duelo; sin embargo, si persiste podría ser un síntoma de alarma. Por otro lado, también se observan casos de personas creyentes que una vez ocurrida la muerte entran en conflicto con su fe, específicamente con Dios, empezando a cuestionar su sentido de justicia y bondad (Díaz, 2014). 


\section{El Duelo en Tiempo de Coronavirus.}

Sufrir la pérdida de un ser querido por Covid-19, es totalmente diferente a como se enfrentaba a la muerte antes de la pandemia. Este escenario hace muy doloroso el proceso de duelo; ya que en el se encuentran resaltados los sentimientos de impotencia y culpa por no poder acompañar y despedir al fallecido al tener que permanecer resguardados en casa. Gracias a la encuesta (Anexo 1) realizada a residentes del área de Lima Metropolitana para saber qué piensan sobre la muerte durante la pandemia, sin necesariamente haber sufrido una pérdida, encontramos que el $60 \%$ de los encuestados piensa que si perdieran a un ser querido en este contexto lo peor sería no poder acompañarlos en sus últimos momentos de vida. El no poder hacer compañía y constatar la muerte de esta persona, hace que surja un conflicto en la elaboración de la primera etapa del duelo: Aceptar la realidad de la pérdida. Por otro lado, el confinamiento y el no poder tener contacto físico, son factores que intensifican el dolor de la pérdida y saturan emocional y psicológicamente a los deudos (Colegio Oficial de Psicología de Madrid , 2020).

Sin embargo, estos no son los únicos factores que dificultan el desarrollo de un duelo normal. En el Perú, la emergencia sanitaria trajo consecuencias fatales. Las historias de familias en busca de una cama UCI, de familias completamente infectadas, de personas buscando con desesperación oxígeno para salvarles la vida a sus seres queridos, de familias sufriendo por saber que uno de los suyos se encuentra aislado lejos de casa teniendo solamente la limitada comunicación de una llamada telefónica, no son novedad, y por desgracia muchas de estas historias terminan en muerte (La República, 2020). En muchos de estos casos, los sobrevivientes, muy aparte de tener que lidiar con sus pérdidas, se enfrentan a otro factor estresor que no les permite el desarrollo de un duelo normal: Las deudas. La falta de cobertura para la atención de casos de COVID-19 en los hospitales del país obligó a muchos a acudir a centros de salud privados que, a pesar de los acuerdos establecidos con el Gobierno, siguieron cobrando cifras exuberantes para tratar a 
este tipo de pacientes. Ante esto, en una entrevista para el diario La República, (Saravia, 2020) se menciona:

Los problemas económicos generan un nivel de estrés muy alto. Y el estrés, en la medida que se va acumulando y haciendo sostenible en el tiempo, se convierte en depresión. Entonces, por una parte tenemos el duelo de la pérdida humana de ese ser querido que ha partido en una forma terrible, en soledad, aislamiento, y sumado a eso personas que no solo se quedaron sin familiar, sino que se quedaron empobrecidas. Probablemente muchas perdieron casa, autos, ahorros, y aun así tienen deudas impagables.

\section{Base Legal en el Contexto COVID-19.}

\section{Directiva Sanitaria $N^{o}$ 087-MINSA/2020/DIGESA}

Contiene las pautas a seguir para el manejo de cadáveres diagnosticados o con sospecha de COVID-19 con el objetivo de resguardar la salud de la población. En el mes de marzo del 2020, se indicó que todos los restos humanos con sospecha de COVID-19 serían cremados, y solo se realizaría la inhumación del cadáver en caso no hubiese un crematorio cercano en el área; sin embargo, en el mes de abril, con la modificación de la directiva, se cambió este punto por permitir a un familiar directo del fallecido decidir si los restos serán cremados o inhumados.

Además indica que el traslado del cadáver y la cremación o inhumación de este, debe realizarse inmediatamente después del deceso, colocándolo en una bolsa hermética que impida el paso de gases y fluidos y que no deberá ser abierta en ninguna circunstancia. En caso de que el deceso ocurra en un establecimiento de salud, se podrá permitir que dos familiares directos visualicen el cuerpo antes de que este sea preparado y trasladado, respetando una distancia mínima de 2 metros; sin embargo, esta posibilidad podrá ser negada si el personal de salud considera que existe algún riesgo de contagio. Cabe resaltar que está prohibido cualquier tipo de contacto físico con el cadáver. 
Todos los cadáveres deben ser cremados o inhumados dentro de las 24 horas posteriores a la indicada en su acta de defunción; por lo tanto, están terminantemente prohibidos los velorios.

En caso de inhumación, el cuerpo permanecerá en una bolsa hermética dentro del ataúd, el cual, una vez cerrado, no puede volver a abrirse. Mientras que en caso de cremación, los dolientes podrán solicitar las cenizas dentro de las 24 horas posteriores al proceso, de lo contrario quedarán a disposición del cinerario.

Si la muerte ocurriese en casa, en la vía pública o en otro espacio distinto al establecimiento de salud, todo caso sospechoso será tratado como positivo para COVID-19 y se permitirá que sólo 2 familiares directos asistan al proceso crematorio y 5 familiares directos, a la inhumación. Además, el cadáver deberá permanecer en la provincia donde ocurrió el deceso, no podrá ser trasladado a una distinta (MINSA, 2020).

\section{Decreto Supremo $N^{\circ}$ 116-2020-PCM}

Este decreto establece las normas de la nueva convivencia social, entre ellas encontramos la prohibición de las reuniones sociales y visitas familiares, ya que estas podrían ser una vía de contagio. Además, señala que se debe evitar el contacto físico y se debe respetar el distanciamiento social no menor a un metro de distancia (El Peruano, 2020).

\section{El Duelo Patológico.}

\section{Terminología.}

Dependiendo del contexto, la época y los autores se han realizado diversos estudios utilizando distintos términos para hablar de este problema; como duelo patológico, duelo complicado, duelo traumático o duelo prolongado. El término "traumático" se volvió poco frecuente al resaltar sólo un factor de riesgo, que es el perder a alguien de forma inesperada y súbita. También dejó de usarse al ser muchas veces confundido con el síndrome de estrés postraumático. Por su parte, el término "complicado" solo indica que es algo difícil de entender y solucionar, lo cual sólo representaría una cualidad pertinente al duelo atípico (Estevan, 2017). 
Uno de los mejores términos para describir el problema sería "prolongado", pues representa la persistencia de síntomas intensos durante años posteriores a la pérdida imposibilitando la aceptación y posterior reinserción a su vida cotidiana dentro de la sociedad (Rosner, 2015). Mientras que, por otro lado, el término "patológico" no sería el adecuado, ya que solo haría referencia a lo negativo de este desorden (Estevan, 2017); sin embargo, para esta investigación este término es ideal, ya que aporta al problema la seriedad de una patología que debe ser atendida de forma profesional.

\section{Definición.}

El duelo patológico es un anhelo y una pena intensa que puede pasar a una sensación de dolor físico y mental provocado por la incapacidad de superar la muerte de un ser querido. A esta situación se le suman sentimientos de incredulidad, eludir ciertos lugares u objetos relacionados con el difunto, sentirse incompleto, perder el sentido de la vida e incapacidad para realizar actividades diarias con normalidad. Ante los primeros 6 meses posteriores a la pérdida los síntomas del duelo normal y el duelo patológico pueden no tener diferencia, sin embargo, en el caso del primero las personas podrán sobreponerse y continuar con sus vidas, mientras que, en el segundo, permanecerán viviendo los síntomas de forma permanente con la misma intensidad (Prigerson et al, 2009).

\section{Tipos de duelo patológico.}

Crónico. El duelo crónico es aquel caracterizado por un dolor permanente y un sentimiento de desesperación que pueden durar muchísimos años. La persona pierde control de su vida, siente que necesita al fallecido nuevamente en ella para seguir viviendo y no puede rehacerla debido a que tiene recuerdos muy fuertes, siente que si la olvida y continúa su vida con normalidad estaría faltando el respeto a su memoria (Cabodevilla, 2007). La persona que lo padece sabe que no puede culminar su proceso de duelo (Vedia, 2016).

Anticipado. Este duelo aparece antes de que el fallecimiento haya ocurrido. La persona que lo elabora sabe que la muerte llegará pronto y esta es una forma de anticipar e ir adaptándose a lo que va a llegar de forma inevitable. Este tipo de duelo es frecuente en 
pacientes con enfermedades terminales o desahuciados y si bien no parece un duelo negativo, solo se sabrá si ayuda en el proceso una vez ocurrida la muerte, si el doliente adapta sus nuevas emociones a la preparación previa puede ser un punto a favor del duelo, pero si el impacto de la muerte genera emociones desbordadas, adelantar el duelo puede generar desorden en el proceso (Cabodevilla, 2007).

Retrasado. Una vez ocurrida la pérdida, la persona tiene una reacción emocional muy ligera que puede ocurrir por una necesidad de mostrarse fuerte ante alguien, por sentirse muy abrumado por la pérdida o por falta de soporte de las personas de su entorno. Si llegara a experimentar otra pérdida en el futuro, podría darse el caso que manifieste finalmente el duelo; sin embargo, este puede darse de forma irregular (Vedia, 2016).

Exagerado. Este se manifiesta a través de un duelo intenso, donde surgen sentimientos desbordados y un comportamiento totalmente desadaptado que puede desencadenar otros trastornos psiquiátricos graves como depresión, ansiedad, estrés postraumático, desarrollo de fobias o abuso de alcohol o drogas. El individuo reconoce que se encuentra en esa situación a causa de la pérdida (Vedia, 2016).

Enmascarado. La persona siente que vive con dificultad y experimenta síntomas de duelo; sin embargo, no reconoce que esto tenga algo que ver con la pérdida. Suelen presentarse síntomas como enfermedades psicosomáticas, hiperactividad o depresión a la cual no encuentran motivo (Vedia, 2016). En estos casos muchas personas acuden a los servicios de salud preocupados por estos síntomas, pero nunca mencionan el hecho de la reciente pérdida pues no la reconocen como causa de sus dolencias (Cabodevilla, 2007).

Inhibido. Se trata de una reacción nula al duelo. Desde las primeras fases el individuo no presenta síntomas regulares. Esto ocurre debido a que esta persona tiene dificultad para expresarse emocionalmente y le cuesta mucho reaccionar ante la pérdida y por esto el proceso de duelo queda congelado y solo empieza a transcurrir cuando es capaz de exteriorizar sus emociones (Cabodevilla, 2007). 
Silente. Esto se produce debido a las normas que tiene la sociedad con respecto al duelo. Al estar establecido cómo, dónde, por qué, con quién y cuánto tiempo vivir el duelo, si se salen de estos límites, los deudos se sienten desamparados por su entorno y sufren en silencio al no sentirse permitidos de expresar sus emociones abiertamente. Se vive una pérdida que no tiene lugar en la sociedad y la persona tiende a ocultarse por vergüenza o miedo a que lo discriminen, rechacen o humillen (Pérez, 2007). Hoy en día, debido al COVID-19, muchas personas que sufren una pérdida debido al virus son discriminadas y evadidas por sus comunidades, por un pánico muy fuerte al contagio. Estas personas estigmatizadas están más propensas a aislarse, sufrir de depresión, ansiedad y vergüenza pública (Centros para el Control y la Prevención de Enfermedades, 2020).

Ambiguo. Este tipo de duelo es un caso particular y se vive con mucha ansiedad. Se presenta de dos formas: La primera es cuando se siente a la persona presente psicológicamente, mas no físicamente, ya que se desconoce si la persona se encuentra con vida o no al no conocerse el paradero de su cuerpo; por ejemplo, en casos de secuestro, extravío o desapariciones. La segunda forma, es cuando la persona está presente físicamente, mas no psicológicamente, como se da en caso de alzhéimer, demencia avanzada, personas con muerte cerebral o en estado vegetal (Cabodevilla, 2007). Este tipo de duelo también sucede en el marco de la pandemia, ya que, en muchos casos, a los familiares no se les ha permitido ver a la persona fallecida, ya sea debido a las normas sanitarias, por haberse encontrado lejos o aislados en sus hogares. Por ende, no ha ocurrido una constatación real de que la muerte haya ocurrido y surge incertidumbre que impide procesar la pérdida a través de preguntas como: “¿Murió en verdad?”, “¿Y si fue un error?, entre otras (COP Madrid, 2020).

\section{Síntomas de Alarma.}

Los síntomas de alarma son aquellos que ayudan a reconocer qué dolientes están entrando a una fase patológica. Es importante conocerlos para identificarlos a tiempo y poder prevenir un futuro desarrollo de duelo patológico. Entre ellos encontramos respuesta nula o muy ligera en las primeras semanas de la pérdida, persistencia de emociones intensas de 
enojo, tristeza, culpa y resentimiento pasadas las primeras semanas de la pérdida, incapacidad para hablar de la persona fallecida sin sentir emociones intensas, incapacidad para separarse de algún objeto perteneciente al difunto o, por otro extremo, deshacerse casi inmediatamente de todo elemento relacionado al difunto, fuerte reacción emocional ante cualquier acontecimiento poco significativo en su entorno, evitar a toda costa hablar del difunto, imitar conductas o experimentar síntomas físicos del fallecido antes de morir, cambiar radicalmente su estilo de vida o su aspecto físico, desarrollar fobia a la muerte o a la enfermedad que acabó con el fallecido (provocando constantes visitas al doctor), actuar impulsivamente haciéndose daño físico a sí mismo, abusar de sustancias dañinas y en casos extremos intentar acabar con su propia vida, no presentar ninguna mejora transcurrido el primer año de la pérdida. Peor aún si no hay evolución a los 2 o 3 años de esta (Cabodevilla, 2003).

\section{Salud mental durante el duelo.}

Antiguamente el duelo se consideraba una aflicción a nivel espiritual, sin embargo, a partir de los estudios de Lindemann (1944), psiquiatra especializado en duelo, quien empieza a describirlo en términos psiquiátricos, el duelo pasa a reconocerse como un trastorno mental y por ende el duelo patológico como una enfermedad que deteriora la salud mental.

La depresión mayor y el duelo patológico. La depresión mayor se caracteriza por un sentimiento de tristeza profunda, pérdida de interés en el mundo exterior y en actividades de disfrute, llanto constante, fatiga, molestia sin motivo, intolerancia, separación social, inutilidad y pérdida de confianza, falta de autoestima e impotencia. Una cantidad considerable de personas que padecen este trastorno tienen ideas suicidas o peor aún, intentos de daño físico o suicidio (Lang et al, 2013) (Gerber et al, 1992).

Las conductas vividas durante el duelo son muy similares a aquellas manifestadas por la depresión. El enfado que nace durante el duelo hacia la persona fallecida finalmente repercute en uno mismo (Freud, 1917). Muchos casos de depresión son causados por las pérdidas, es así como el duelo intenso se transforma en una depresión real muy fuerte, ya sea después de la 
pérdida o debido a los recuerdos que producen (Klerman et al, 1974). Esta depresión también se podría generar como un método de autodefensa ante el duelo, pues si todas las sensaciones negativas son dirigidas a sí mismo, el foco de atención y el "enfrentamiento" hacia el fallecido se evita (Dorpat, 1973).

Tanto en el duelo como la depresión podemos encontrar síntomas comunes como trastornos de sueño, alimenticios o tristeza aguda, mas no encontramos problemas de autoestima como generalmente sucede en las depresiones clínicas. Con esto se puede observar que las personas que sufren una pérdida no sienten que pierden su valor personal debido a ella y si sienten culpa esta está relacionada con algún factor directo a la muerte más que con ella misma (Worden, 1997). Ambos son estados distintos, mientras que durante el duelo el mundo parece vacío, durante la depresión, el individuo se siente vacío (Freud, 1917).

\section{Cambios de comportamiento.}

Cuando se presenta un trastorno depresivo mayor durante el duelo, aumenta la existencia de sensación de inutilidad, pensamientos suicidas, bajo rendimiento laboral, déficit a nivel social y la probabilidad de que ocurra esto es mayor en individuos con antecedentes depresivos (Vedia, 2016). El duelo patológico lleva a las personas a aislarse, siempre están distraídos, se sienten incapaces de responder ante las exigencias del día a día, adoptan conductas como beber sustancias alcohólicas u otras sustancias en exceso, comer demasiado o no comer y auto medicarse. Todo esto como una señal de completo desinterés y abandono ante la vida y ante lo que les pueda pasar. (Echeburúa y Herrán, 2007).

\section{Factores de Vulnerabilidad.}

Estos factores hacen referencia a qué tan predispuesta está la persona a desarrollar un duelo patológico después de experimentar la muerte de un ser querido. Identificando el nivel de riesgo se puede reconocer cuándo se debe hacer seguimiento a un caso para que este se desarrolle con normalidad. Una persona puede tener riesgo de sufrir duelo patológico, pero no necesariamente lo desarrollará (Aranda y Milne, 2000). 
Circunstancias de la muerte.

La manera en cómo fallecen las personas tendrá una relación directa a cómo irá

evolucionando el duelo de los deudos (Worden, 1997). Teniendo en cuenta, la manera en la que mueren las víctimas del COVID-19, donde los familiares además, tienen que vivir un sinnúmero de emociones y otros factores estresores (formas de movilización, deudas, búsqueda de medicamentos, etc.) desde el momento del diagnóstico, los dolientes están totalmente vulnerables a presentar complicaciones en el duelo. (COP Madrid, 2020).

\section{Muerte traumática.}

Se refiere a muertes súbitas y violentas como accidentes automovilísticos, laborales, asesinatos, enfermedades cortas (como el Coronavirus), entre otros. En estos casos el duelo se ve acompañado con algunos síntomas o el desarrollo total del trastorno de estrés postraumático. Los dolientes tienen constantes flashbacks del evento de la muerte que incluyen imágenes, pensamientos, voces y visiones del mismo, sueñan con aquel momento generando problemas para conciliar el sueño, tienden a pensar que el evento traumático ocurre en ese preciso momento, no siente esperanzas en el futuro, reprime su afectividad hacia los demás, disminuye su interés en actividades que antes disfrutaba, tiene dificultad para concentrarse y siempre se encuentra deprimido e irritable (Díaz, 2014).

\section{Muerte por homicidio.}

Tiene como característica inicial un fuerte impacto que lleva a la persona a creer que esto no está pasando. Después, entra en un estado donde contrae sus emociones a modo de autodefensa y puede permanecer así durante muchos meses posteriores a la muerte. También experimenta episodios de enojo, extrema preocupación por la forma en la que su pariente murió, terrores nocturnos, recuerdos repentinos, flashbacks y entre estas sensaciones encontramos 4 síntomas característicos del duelo patológico, como son la culpa, la rabia, el miedo y la vergüenza (Malone, 2007). 
Familiares desaparecidos.

Cuando una persona desaparece, el duelo es confuso y doloroso, pues la persona no sabe en qué momento empezar a vivir el duelo, ya que en un inicio solo consigue sentir mucha ambigüedad y duda. En estos casos, como algunas veces se ha podido observar en medios de comunicación, las familias exponen sus casos públicamente en busca de respuestas y señales que aumenten la esperanza de poder encontrar con vida a esta persona; sin embargo, cuando el caso se conoce por una cantidad considerable de personas, las familias deben lidiar con algo más: Las diferentes opiniones que la sociedad pueda dar sobre esto y, además, cada vez que se toque el tema en los medios la familia siente que revive este evento (Díaz et al, 2014).

\section{Muerte por suicidio.}

Esta causa de muerte provoca un duelo traumático y agotador porque surge la incomprensión, los dolientes quedan con muchas preguntas sin respuesta respecto a la muerte, niegan el suicidio, empieza a generar teorías en torno al motivo de la muerte y podrían tener siempre la imagen de la escena del suicidio en la mente. Este tipo de muerte repentina no les permite a los dolientes despedirse ni solucionar asuntos pendientes con el suicida (García-Viniegras y Pérez, 2013).

\section{Muerte perinatal.}

Mientras más cerca se encuentre el momento del parto, se produce una carga psicológica ambivalente en los futuros padres, se siente emoción y anhelo por finalmente conocer a su hijo, pero también miedo al parto o que algo pueda sucederle al bebé o a la madre. Entonces, si no se llega a cumplir la expectativa de la maternidad los cambios a nivel psicológico, especialmente en la madre, quien es la que ha desarrollado mayor afectividad el tiempo que haya durado la gestación, son abruptos y traumáticos (García y Yagüe, 1999). 
Vínculo con el fallecido.

Si hablamos del vínculo con papá o mamá. Un estudio centrado en este tipo de pérdida realizado por Kalter et al en el año 2003, indica que perder a un padre puede ser uno de los eventos más perturbadores en la vida del ser humano y desata comúnmente depresión, ansiedad y síntomas somáticos.

Por otro lado, es algo inesperado ver a un padre enterrar a su hijo, tanto así, que no existe un término que describa al padre que pierde un hijo, así como "huérfano" describe la pérdida de un padre o "viuda/o" describe a quien pierde a su esposa o esposo. El estrés que genera esta situación puede provocar incluso la separación o el divorcio de la pareja si es que no encuentran formas saludables de lidiar con el duelo juntos. El dolor siempre vuelve a surgir en cada cumpleaños, aniversario de fallecimiento, navidad u otros eventos (Echeburúa y Herrán, 2007). Aproximadamente el $20 \%$ de padres que pierden a un hijo nunca llegan a superar la pérdida (Pérez, 1999).

Por su parte, el perder una pareja, en especial cuando existía una situación de dependencia emocional o cuando el doliente carece de la resiliencia suficiente para adaptarse a su nuevo contexto solo, la muerte provoca un impacto emocional muy fuerte (Echeburúa y Herrán, 2007).

\section{Pérdidas acumuladas.}

Una persona que haya experimentado pérdidas previas o simultáneas está más propensa a tener una complicación cuando se enfrente a una nueva pérdida (Acinas, 2012), Conocer sobre las pérdidas anteriores de persona proporciona información sobre cómo ha superado o no sus antiguas pérdidas y así visualizar las probabilidades de cómo se desarrollará la pérdida actual (Worden, 1997).

\section{Familia y apoyo social.}

Durante el duelo el apoyo social es necesario, entonces, cuando este es nulo, inadecuado, asfixiante o abrumador puede ser perjudicial. Situaciones como rechazar al doliente, silenciarlo, echarlo de su centro de labores, ser rechazado por sus centros culturales o 
religiosos o por el otro lado, intentar sobreprotegerlos de cualquier sensación de dolor son muy dañinas para la persona (Acinas, 2012).

La cultura, creencias y entorno familiar influyen directamente en el doliente y lo que él obtenga de su familia será lo que Worden (1997) llama "ganancia secundaria” y se trata de aquella atención especial que recibe de los suyos mientras se encuentra en duelo; sin embargo, cuando el duelo dura más tiempo de lo normal la ganancia secundaria se pierde y el doliente termina por apartarse y aislarse su entorno social.

\section{Inestabilidad emocional previa.}

Tener antecedentes en trastornos de salud mental como ansiedad, depresión, problemas de autoestima, alguna discapacidad física, incapacidad para exteriorizar y compartir sentimientos, son un obstáculo para llevar a cabo el proceso natural del duelo (Acinas, 2012).

\section{Diagnóstico.}

En 1999, H. Prigerson y su equipo, sugirieron una serie de criterios para detectar el duelo patológico: Criterio A, un cuadro de estrés provocado por la separación causada por la muerte. Una vez ocurrida la pérdida, el doliente experimenta todos los días tres o cuatro de los siguientes síntomas: Pensamientos sobre el difunto que entran de repente y sin control en su mente, extrañar intensamente al difunto, buscarlo sabiendo que ya no está vivo, sentirse absolutamente solo y abandonado por el difunto.

Criterio B, un cuadro de estrés provocado por el impacto de la muerte. El doliente experimenta diariamente mínimo cuatro de los ocho síntomas siguientes: No tiene visión ni metas a mediano o largo plazo y se siente inútil ante lo que le depara el futuro, no manifiesta emociones y se expresa y comporta con frialdad e indiferencia, no acepta la pérdida, siente que la vida carece de sentido y se siente vacía desde que ocurrió la muerte, siente que una parte de sí murió junto con aquella persona, su manera de ver e interpretar el mundo cambió, tiene la sensación de padecer síntomas o conductas destructivas relacionadas con el difunto, está muy irritable y enojado por la muerte. 
Criterio C, este tiene que ver con la duración del trastorno e indica la presencia de los síntomas previamente explicados por seis meses o más.

Finalmente, el Criterio D, que corresponde a si el trastorno ya está deteriorando la vida laboral, social y otros campos dentro de sus actividades diarias significativamente.

\section{Estrategia Terapéutica.}

El doliente debe buscar ayuda profesional, cuando vive de forma irregular y alterada durante un periodo de 4 a 6 semanas (Echeburúa y Herrán, 2007). Para estos casos la estrategia terapéutica consiste en tratar al doliente de manera individual o grupal; sin mencionar que en algunos casos la combinación de ambas es necesaria. La primera es más específica y trabaja directamente con las emociones que le generan dolor al paciente. Mientras que la segunda utiliza el apoyo familiar para ayudar al doliente a expresarse, encontrando apoyo en los suyos para lograr normalizar poco a poco el desarrollo del duelo y así terminar con el aislamiento. Cabe mencionar, que cada persona progresará a su propio ritmo, por este motivo el especialista debe ser flexible ante las respuestas del doliente (Barreto y Soler, 2004).

El objetivo de la intervención terapéutica no es borrar el recuerdo del fallecido, sino que este tome un lugar en la memoria del doliente de forma que el recuerdo no afecte ni bloquee la normalidad de su estilo de vida. De forma más específica, se intenta minimizar la tristeza, la ansiedad, el aislamiento e incrementar los niveles de autoestima con el objetivo hacer que esta persona viva de forma saludable (Rando, 1993).

Existen 5 metas que se sugieren alcanzar durante el tratamiento para asegurar el éxito de recuperación. Primero, lograr que el doliente exprese los sentimientos que tiene contenidos a través de historias o relatos que quiera contar sobre el fallecido. Segundo, hablar del momento de la muerte, cómo sucedió, bajo qué circunstancias, qué hizo, qué no hizo, etc. Tercero, habiendo elaborado el punto 1 y 2 , ser capaz de procesar la historia que ha contado y asimilar información que tal vez antes pasó desapercibida. Cuarto, focalizar el tratamiento en la resolución de los problemas que lo aquejan a diario y que le impiden 
adaptarse a su estilo de vida. Quinto, hacer que se tenga una visión de sí mismo a futuro, incentivándolo a que realice actividades que le causen gratificación (Echeburúa, 2004) (Ruiz y Cano (2002).

\section{Psicológica.}

Esta suele ser la primera ayuda especializada a la que acude una persona con trastorno de duelo patológico y en ella se aplica un tipo de psicoterapia similar a la utilizada para tratar la depresión. Esta terapia funciona tanto de forma individual como grupal y en ella se puede resolver las dudas que tenga sobre su trastorno y tratamiento, explorar cómo reacciona el doliente ante ciertos estímulos, así como sus emociones. Se trabaja directamente con el recuerdo del evento traumático para que estos no liberen más angustia (Mayo Clinic, 2017)

\section{Psiquiátrica.}

Este tratamiento está dirigido para controlar síntomas como la depresión, ansiedad, problemas para dormir, entre otros. Normalmente este tratamiento suele tratarse a la par con fármacos como antidepresivos (Mayo Clinic,2017).

\section{Indicadores de Recuperación.}

La primera señal que puede indicar que el doliente se está recuperando es que este normalice sus niveles de sueño y apetito. También, otro signo de recuperación es cuando logra verbalizar sus emociones de forma satisfactoria logrando expresar lo que siente de forma honesta, ordenando en su mente todos aquellos recuerdos, flashbacks e imágenes de la muerte. A esto le podríamos sumar la capacidad de expresar afecto ya sea gestual o físico. Se observa en el doliente que ahora tiene metas y objetivos que quiere alcanzar, retoma su papel dentro de sus relaciones sociales, aumentando su autoestima y logrando recobrar el sentido de su camino (Echeburúa y Herrán, 2007).

El duelo patológico termina cuando se asimila la pérdida, cuando la persona, aun sintiendo tristeza, puede aceptar la pérdida como algo que ya ha sucedido y que ahora solo forma parte de su historia y puede traer a su recuerdo sin sentir emociones negativas; por el 
contrario, es capaz de superponer recuerdos positivos que vivió con esa persona en vez de enfocarse en lo negativo. Es así como este recuerdo deja de afectar y puede retomar su vida con tranquilidad y disfrutar de ella (Worden, 1997).

\section{Diseño de Producto.}

La Escuela de Diseño de Madrid (ESDIMA) define el diseño de producto como el proceso de creación de este, empezando desde la concepción de la idea, estrategia, análisis, desarrollo y diseño hasta llegar a la evaluación, corrección y conclusión (ESDIMA, s.f.).

La creación de un nuevo producto siempre será la respuesta a un problema o necesidad.

\section{Diseño y calidad de vida.}

La calidad de vida es la característica de una sociedad que está debidamente acondicionada para facilitar la vida de quienes la componen, apoyándolos de forma física o mental para que los problemas en el ambiente no interfieran con su día a día. Ante esto, el diseño se aplica para crear productos u objetos útiles y bien pensados que satisfagan mejor las necesidades de los demás obteniendo el mejor grado de satisfacción y bienestar (Ricard, 1987).

\section{Valores del producto.}

Los valores del producto son subjetivos e influyen en la adaptación y aceptación del producto y muchas veces serán los determinantes de la decisión de compra. Entre ellos se encuentran la estética, que refleja la belleza visual del producto, suele asociarse con la calidad y es la primera interacción entre el producto y el consumidor. Por otro lado, está el styling, que consiste en el desarrollo de productos que cumplan con las expectativas estéticas del consumidor, sin alterar la funcionalidad y rentabilidad del producto. Por su parte, el estilo es la apariencia externa del producto que codifica contenido cultural y social. Mientras que otro valor importante es el color, que otorga al producto una carga emocional y tiene la capacidad de destacarlo, convirtiéndolo en el foco de atención, también puede unificar o separar sus piezas y puede romper con la proporción y cambiar su orientación (Iváñez, 2000). 
Producto personalizado.

La exigencia de los consumidores por adquirir productos únicos que expresen

individualidad y con los cuales se sientan identificados va en aumento y el proceso de este tipo de productos implica una comunicación directa con el consumidor para conocer realmente qué es lo que quiere y hacia donde están orientados sus gustos y necesidades. La personalización de productos permite a los usuarios sobrepasar la barrera de lo material y entrar en un plano emocional. Se relacionan mejor con el objeto y le otorgan un carácter más significativo y sentimental que le permitirá vivir experiencias gratas y reconfortantes, creando lazos más duraderos con el producto y la marca (Norman, 2005).

\section{Handmade.}

Esta es una tendencia que hace referencia a todo producto que tiene un proceso de fabricación manual. Gracias a esta cualidad, es posible intervenir el producto en cualquier fase de la producción, lo cual permite un mayor control y personalización de este. Un producto hecho a mano o artesanal, es más atractivo ante sus competidores, los productos industrializados; ya que son más personales y significativos. Además, tienen la característica de ser ecológicos, pues reutilizan elementos de un solo uso que normalmente serían desechados (Pariente, 2014).

\section{Sostenibilidad.}

Debido al desgaste del medio ambiente, varias disciplinas decidieron reinventar sus procesos para reducir su impacto en el planeta y el diseño no ha sido la excepción. La sostenibilidad implica satisfacer necesidades actuales sin perjudicar a las generaciones futuras (Brundland, 1987). Mientras que el diseño gráfico sostenible busca resolver problemas, teniendo en cuenta que la elección de materiales y procesos de producción tendrán un impacto directo con el ambiente, la sociedad y la economía (Muñoz, 2014). El diseñador tiene tres roles importantes en el proceso de diseño. El primero es como manipulador del material, aquí tiene la oportunidad de optar por el uso de materiales beneficiosos para la conservación del ambiente como por ejemplo, papel reciclado, cajas 
reutilizables, uso de sellos y tintas con bajo nivel tóxico. El segundo es como creador del mensaje, aquí tiene la posibilidad de generar ideas que inviten al desarrollo ambiental. El tercero es como agente de cambio, aquí el diseñador influye en la mentalidad del consumidor cambiando su perspectiva ante una determinada situación. De esta manera se puede observar que un proceso de diseño bien pensado puede generar un impacto positivo en el entorno (Dougherty, 2008).

\section{Eco-eficiencia.}

El diseño gráfico eco-eficiente es una forma de llegar a la sustentabilidad que significa hacer más con menos, aprovechando al máximo los recursos y generando menos desperdicios, promoviendo la conservación del ambiente (McDonough y Braungart, 2002). Estrategias generales. Es importante tomar las decisiones correctas durante la cadena de diseño y producción; por ello se deben tomar en cuenta las siguientes estrategias al momento de elaborar los productos: Elegir insumos con certificados o etiquetas ecológicas, utilizar la cantidad de empaques necesaria, reducir el transporte, adquirir productos que ahorren agua o energía en su elaboración, en caso de que el producto sea de un solo uso, utilizar materiales biodegradables o reciclables, inclinarse siempre por materiales no tóxicos y en lo posible reciclados e imprimir solamente las piezas necesarias (Ecodiseño CBA, s.f.).

Estrategias para la selección y uso del papel. Usar cartón, papel u otros materiales elaborados con fibras recicladas evitando la menor cantidad de fibras vírgenes en el material, usar papeles con certificación de control forestal y tipo de blanqueado como FSC (Forest Stewardship Council), PEFC (Programme for the Endorsement of Forest Certification), ECF (Elemental Chlorine Free), TCF (Totally Chlorine Free), entre otros, utilizar el pliego de papel en su totalidad y reducir el tamaño del diseño para reducir el uso de papel, reducir el gramaje al mínimo posible dependiendo de la necesidad y finalmente usar, en lo posible, ambos lados del papel (Ecodiseño CBA, s.f.).

Estrategias para la selección y uso de tintas. Usar la menor cantidad de tinta posible y la mínima cantidad de tintas diferentes, optar por aquellas hechas a base de agua o vegetales y 
que sean biodegradables, evitar tintas metalizadas o fluorescentes o usar como sustituto pigmentos minerales naturales y por último, evitar acabados brillantes como barniz o laminados pues dificultan el reciclaje del papel (Ecodiseño CBA, s.f.).

\section{Diseño de Empaque.}

El diseño de empaque, también conocido como packaging, surgió en el siglo XIX cuando pequeños fabricantes comenzaron a envasar sus productos para la venta, logrando diferenciarse de la competencia, favorecer su imagen, proteger el producto y hacer más fácil su distribución (Calver, 2004).

Los productos necesitan de un empaque para protegerlos de cualquier cosa que pueda dañarlos o perjudicar su funcionalidad. Además es una pieza importante para presentar tanto el producto como la marca, ya que en su superficie se puede comunicar información importante sobre ambos, a través del uso del texto, imágenes y otros elementos de comunicación, dándole características a la marca para que esta pueda llegar a diferenciarse y posicionarse en la mente del consumidor (Ambrose y Harris, 2011).

Al momento de diseñar un empaque, se debe tener en cuenta al usuario y cómo se van a cubrir sus necesidades pensando en cómo lo transportará, cómo lo manipulará y cómo lo almacenará. Por ello es importante saber cómo se comporta el consumidor desde el momento de compra hasta que termina de usar el producto (Calver, 2004).

Este proceso está ubicado entre el diseño gráfico y el diseño de producto. Es cercano al diseño gráfico cuando interviene en el diseño o modificación de superficies de dos dimensiones como etiquetas o cajas. Mientras que, por otro lado, se relaciona al diseño de producto al momento de crear o modificar un embalaje funcional. Por otro lado, involucra un plano tridimensional cuando el diseño está enfocado en el desarrollo de un nuevo envase; como por ejemplo, una nueva botella de perfume (Cotec, 2008).

Aquí, también se debe tener muy en cuenta el uso de materiales y uno de los más comunes para empaquetar es el cartón, ya que se puede adaptar a distintos tamaños y formas, se puede controlar su peso, es manejable y facilita el proceso de impresión. Los materiales 
otorgan al producto distintos atributos como calidad, elegancia, modernidad, etc. y son de gran ayuda para darle un valor agregado que ayude con su identificación y preferencia, mostrando a la marca de forma atractiva (Fishel, 2007).

\section{Branding.}

Las personas no compran productos, sino marcas. La marca es la madre de todas las cualidades del producto y es importante que sea capaz de competir, ya que hoy en día existen muchísimos productos similares que intentan ganar el foco de atención dentro de la misma categoría y solo una marca sólida y bien construida, acompañada de una buena imagen, puede hacer la diferencia (Cotec, 2008).

\section{Estado del Arte.}

\section{Retratos y murales en homenaje a las víctimas de COVID-19.}

El artista gráfico Daniel Manrique, observó cómo su barrio de Leticia en el Cerro San Cristóbal en Perú se convertía en uno de los más afectados por la pandemia provocada por el COVID-19 entre los meses de junio y julio de 2020 y sus vecinos solo podían observar con impotencia cómo sus seres queridos fallecían. En medio de todo el dolor, Daniel decidió ir casa por casa para entregar él mismo un retrato del ser querido fallecido a sus respectivas familias. Con esto él tiene la intención de aliviar un poco su dolor y las familias respondieron positivamente expresando un gran sentimiento de gratitud y sosiego. La comunidad respondió positivamente a este estímulo, y muchas personas empezaron a contactarlo para que también pueda hacer retratos de sus familiares fallecidos y así rendirles homenaje responsablemente desde la seguridad de sus hogares. Ahora Daniel tiene la intención de llenar las paredes del barrio de Leticia con murales que homenajeen a sus vecinos fallecidos y, además, aporten un mensaje de concientización al resto de la comunidad (RT en Español, 2020).

\section{Campaña “¿Cómo ayudar a un zombi?”}

La fundación española Menudos Corazones lanzó la campaña “¿Cómo ayudar a un zombi?" en el año 2015 dirigida a aquellas personas que no saben cómo ayudar a un padre 
que ha sufrido la pérdida de un hijo. A través de ella quisieron transmitir un mensaje para sensibilizar a la sociedad sobre cómo se debe interactuar con una persona que se encuentra atravesando el duelo. La campaña se lanzó con un video publicado el 22 de junio que, a través del storytelling, explica qué es un zombi y cómo ayudarle a que regrese a la vida explicando que el zombi realmente es una persona sensible y frágil a la cual los humanos pueden ayudar sin causarle daño. La metáfora del zombi surgió de la experiencia de una de las madres del grupo de apoyo en duelo de la fundación, quien dijo sentirse como un “zombi” después de la muerte de su hija. Además, la fundación se alió con Boston Scientific y PARCESA, invitando a la gente a difundir el video a través de las redes sociales, ya que, cuando este alcance las 40000 vistas, ambas empresas donarían 4000 euros a la fundación para que sean invertidos en ayuda psicológica para las familias más necesitadas (Somos pacientes, 2015).

El objetivo principal de esta campaña fue sensibilizar a la sociedad acerca del duelo y finalmente el mensaje tuvo mucha acogida. Muchos usuarios que pasan por lo mismo se sintieron identificados, mientras que aquellos que no, la figura del zombie les permitió ponerse en el lugar del otro. El video fue compartido por muchísimos usuarios, blogs y páginas web.

\section{Cajas de recuerdo.}

La asociación sin fines de lucro Umamamita que se encarga de apoyar a padres de familia en duelo por muerte perinatal, realizó el proyecto "Cajas de recuerdo" dirigidas a padres que sufrieron una muerte intrauterina, interrupción de embarazo a partir de la semana 14 hasta el momento del parto o muertes neonatales. Esta caja se creó bajo el concepto de la importancia de los recuerdos tangibles y las fotografías, ya que estas piezas ayudan a mantener una conexión con su hijo o hija fallecido y asimismo, darles una identidad como padres ante la sociedad y sus familias. Su objetivo principal es ayudar a que estos padres puedan vivir el duelo adecuadamente y sentir apoyo social que los encamine a poder llevar 
un duelo normal e invitan a implementar este producto en hospitales donde atiendan este tipo de casos.

La caja de recuerdo contiene material informativo y piezas diversas que ayudarán a generar lazos con el bebé, entre ellas se encuentran: Una manta y gorro tejido por voluntarias de la asociación, un pañal, dos peluches pequeños (uno puede acompañar al bebé, mientras que el otro puede irse a casa con los padres), dos colgantes con diseños de mariposa y estrella, kits de toallitas sin tinta para que los padres puedan sacar huellas de las pies y manos de su bebé, arcilla blanca para hacer huellas y una velita LED. Por otro lado, entre los documentos informativos que se adjuntan en la caja se encuentran: Información sobre Umamamita y otros grupos de ayuda local, un certificado de nacimiento sin validez legal, folletos sobre el duelo, como crear recuerdos, autopsia, unidad de cuidados intensivos neonatales y sobre cómo usar la caja, y por último un sobre con la dirección de Umamanita y una tarjeta con algunas preguntas sobre la caja (feedback) que la familia puede enviar más adelante (Umamamita, s.f.). 


\section{Capítulo IV}

\section{Público Objetivo.}

Este proyecto está dirigido a todas las personas de 38 años a más que hayan sufrido la pérdida de un pariente cercano o ser querido en el contexto de la pandemia a causa del COVID-19 en Lima Metropolitana. Este grupo es especial, porque a pesar de las particularidades de cada uno de los casos, todos comparten un factor común, que es la dificultad que están teniendo para sobrellevar el duelo por haber respetado las nuevas normas sanitarias para prevenir el contagio.

Este actor es importante porque a pesar de que las muertes son relativamente recientes y muchos de los procesos de duelo aún están en desarrollo, es aquí donde se debe ofrecer un soporte adecuado para encaminar un duelo sano y prevenir que a largo plazo este duelo no se convierta en una patología.

Lo que caracteriza a este grupo es que son personas que han sufrido una o varias pérdidas en el mes de marzo o posteriores, a causa del COVID-19. Además, en este rango de edad, es muy probable que ya hayan sufrido alguna otra pérdida en tiempos previos a la pandemia aumentando su vulnerabilidad. Entre los dolientes más afectados predominan las mujeres, pero también se observa un dolor profundo en varones.

Viven en familia ya sea acompañados de hermanos, padres, hijos o esposo o pareja. La mayoría tiene educación básica y varios, estudios técnicos o superiores y desempeñan algún tipo de trabajo. Son creyentes, expresan constantemente ideas o pensamientos sobre Dios y utilizan expresiones como: “Que Dios lo ayude", “Ahora está con Dios”, "Dios lo tiene en su gloria", "Por qué Dios me lo quitó", “Este es un castigo de Dios”, etc.

Son personas adultas que utilizan la red social Facebook desde un dispositivo móvil o de escritorio y utilizan este medio para expresar públicamente pensamientos o sentimientos hacia su familiar fallecido. Publican fotografías del fallecido o comparten imágenes con pensamientos relacionados a la pérdida en las cuales interactúan con otros usuarios. 
Son personas bastante sensibles, que sienten gran dolor, muchas de ellas intentan ser fuertes, no para sentirse mejor, sino para poder lidiar con sus responsabilidades (el cuidado de los hijos, de la familia, del hogar, el trabajo, etc).

Es muy difícil para ellos vivir su duelo porque sienten que no tienen un buen recuerdo de la persona fallecida, tienen miedo a que el virus los contagie a ellos o a sus seres queridos, además del estrés y la presión de la vida diaria. Reprimen muchas emociones por eso al momento de hablar del tema sienten un nudo en la garganta y se les hace muy difícil hablar de ella. Los sentimientos más comunes en estas personas son culpa y enojo, por no poder hacer nada por sus seres queridos en sus últimos momentos de vida y no poder darles la despedida digna que se merecían.

Tienen un círculo de amistades y familiares con los cuales suelen comunicarse a través de las redes sociales, o por llamadas telefónicas (por iniciativa del amigo o familiar de tercer grado). Les causa tristeza no poder apoyarse físicamente en estas personas y no les gusta sentirse solos.

\section{Concepto.}

Para el desarrollo de este proyecto, se usó de base el concepto “Abrazos que sanan a la distancia”. Con el se busca reflejar amor y empatía hacia la persona en duelo.

Cuando alguien fallece, el impacto de recibir la triste noticia es como una puñalada. La herida que provoca el duelo es como cualquier otra que se pueda hacerse en la piel. Al inicio, dolerá, sangrará y causará llanto. Luego estará cubierta con vendajes; sin embargo, el ardor permanecerá. No será fácil vivir la rutina con la normalidad de antes ya que aún habrá un dolor punzante. Será necesario aceptar el proceso natural para que sane hasta poder ver una cicatriz en la piel. Cada vez que se vea esta cicatriz, traerá el recuerdo de todo lo que hay tras ella.

Muchas veces, cuando la gente se encuentra con algún familiar, amigo o conocido que perdió a un ser querido, no encuentra las palabras adecuadas para reconfortarlo, o en muchos casos puede perjudicar el proceso con frases poco constructivas. A veces la mejor 
manera de mostrar verdadera empatía es a través de acciones y gestos silenciosos como un simple abrazo. Dar un abrazo significa dar tranquilidad, energía y fortaleza para seguir adelante y sobre todo es una forma de decirle al doliente que no está solo.

Ahora, que no es posible abrazar como antes debido a la pandemia, se debe hallar la forma de transmitir la energía de un abrazo a pesar de la distancia, para ayudar a esta persona a sanar la herida del duelo.

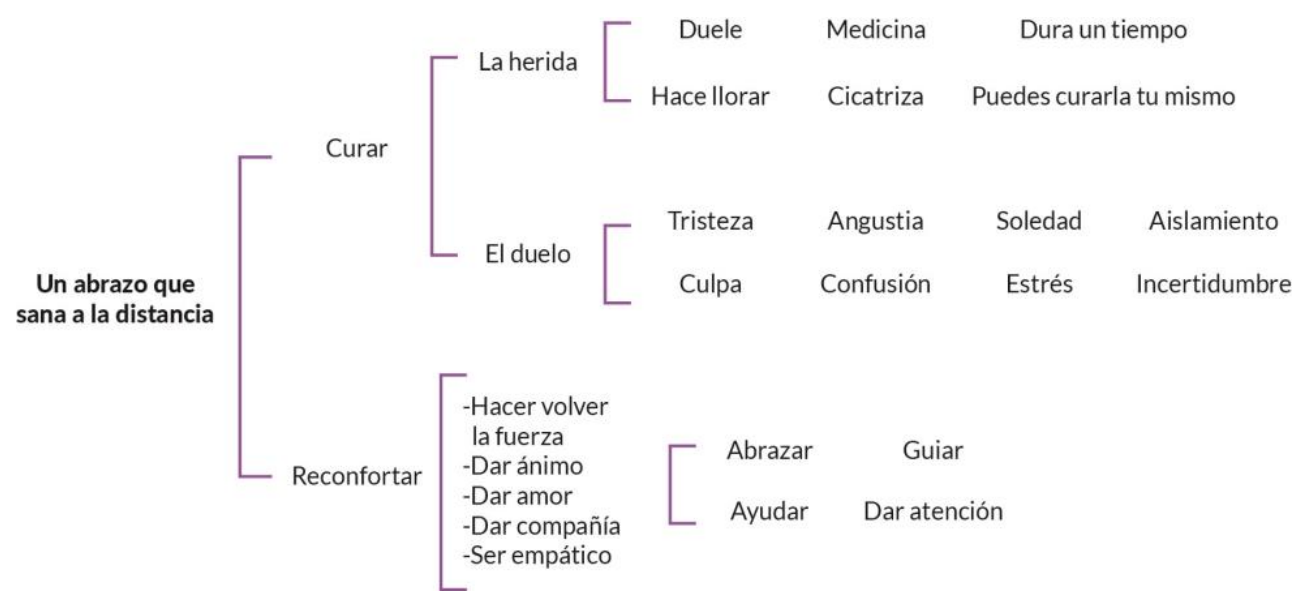

Figura 2 Análisis del concepto. Fuente propia

\section{Moodboard.}

Se planteó reflejar las características del concepto a través de un moodboard para reflejar de manera visual el carácter del proyecto y la importancia de apoyar a una persona en duelo con cariño y empatía.

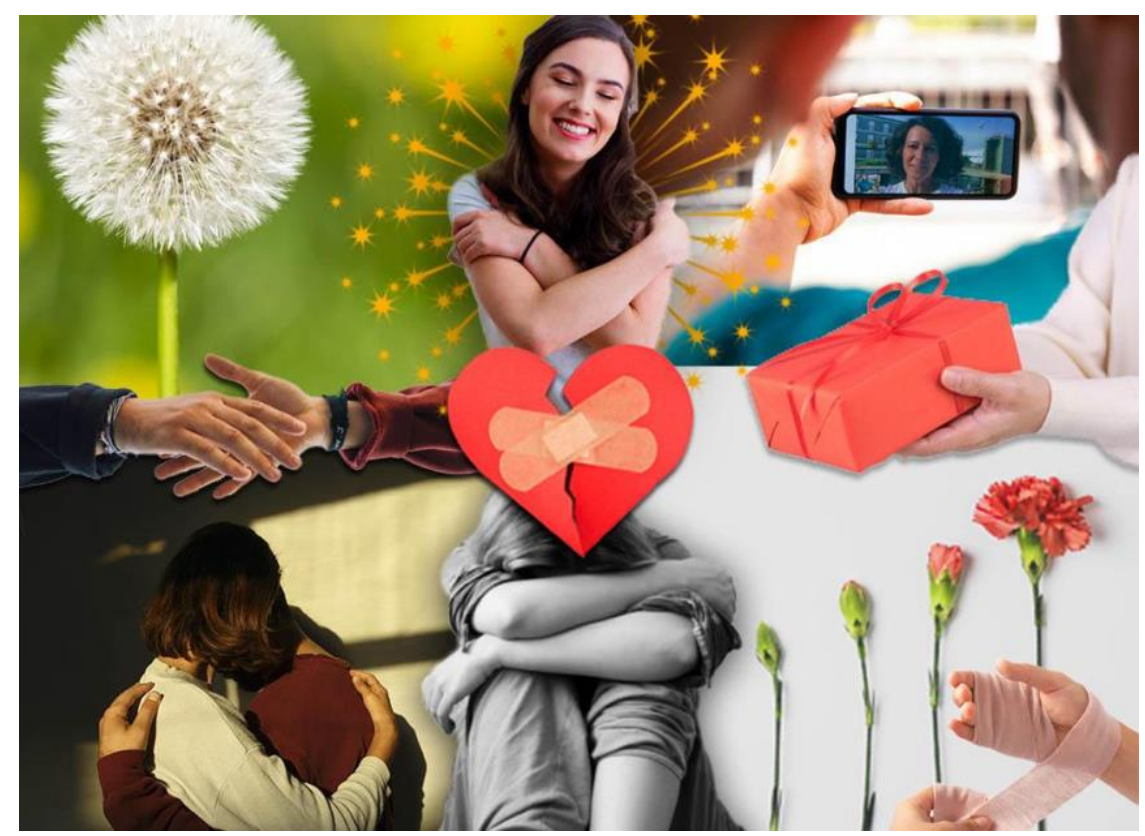

Figura 3 Moodboard del concepto. Fuente propia. 
Paletas de color.

Gracias al análisis previo se pudo elaborar una paleta de color que identifique al proyecto, concluyendo en el uso de colores cálidos. A través de ellos se busca representar el abrazo que brinda apoyo a las personas en duelo para que puedan ir poco a poco sanando sus heridas.

La elección de estos colores permite transmitir sensaciones agradables y estimulantes. Los todos rosados aportan una característica amable, suave y cariñosa, mientras que el primer tono amarillo le da calidez, optimismo, luz y energía sutil. Por último, el rojo oscuro le da el valor de fuerza de voluntad y soporte para superar el momento.

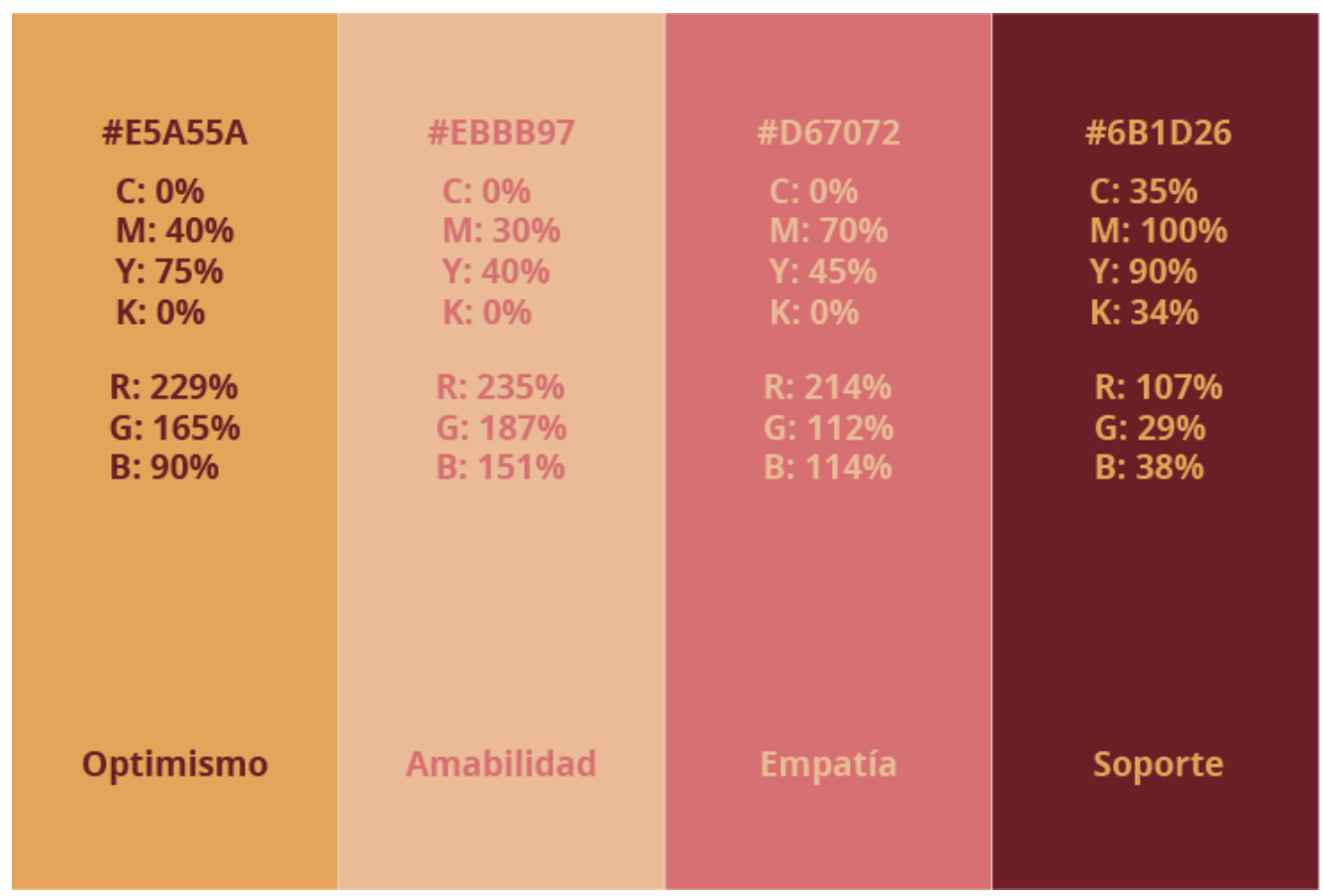

Figura 4 Paleta de color. Fuente propia.

\section{Tipografías.}

Se eligió una tipografía capaz de reflejar el concepto. Para la creación del logo la tipografía Coolstory fue útil para reflejar amabilidad, cercanía y además el carácter "hecho a mano" del proyecto, dándole una apariencia más personalizada. Por otro lado, para diseñar las piezas se hizo uso de la tipografía KG Empire of Dirt que es versátil, amigable y con mayúsculas y minúsculas fáciles de leer. Además, se eligió como tipografía complementaria Open Sans y sus variaciones para cuerpos de texto y otros detalles. 


\section{Coolstory regular \\ ABCDEFGHIJKMNOPQRSTUVWXYZ \\ abcdefghijklmnopqrstuvwxyz \\ 1234567890}

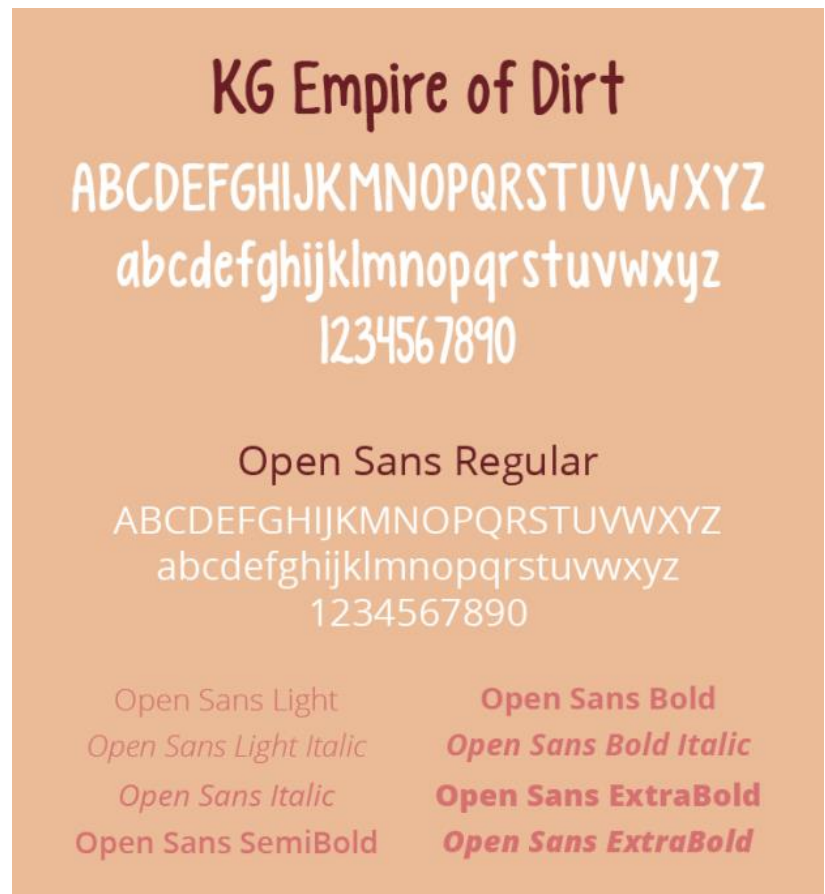

Figura 5 Tipografías. Fuente propia.

\section{Proyecto de Diseño.}

El proyecto consiste en el diseño de un producto capaz de ayudar a las personas a atravesar el proceso de duelo, previniendo el desarrollo del duelo patológico. En este caso, se eligió realizar un set de piezas contenidas en una caja, cuyo destino final será las manos del doliente. Cada pieza tiene el objetivo de aportar algo positivo durante las distintas etapas del duelo y así poder reducir los sentimientos negativos, permitiendo que el doliente vaya asimilando la pérdida a su propio ritmo de manera saludable.

Este proyecto facilitará la elaboración del duelo haciendo el proceso lo más saludable y natural posible. Además, al normalizar el proceso de duelo se detecta y previene el desarrollo del duelo patológico, así como otros trastornos relacionados con la pérdida como cuadros depresivos y ansiosos. Es una forma de apoyo emocional y guía para reducir el dolor y hace posible volver a equilibrar su estado de ánimo y sentido de vida. 
Como primer paso para la elaboración del set, se realizó la elección de piezas. Para ello, se conversó con la licenciada en psicología Tatiana Dunezat (Anexo 2)(Anexo 3), quien aclaró conceptos clave referentes al tema y sugirió algunas de las mejores estrategias para ayudar a la resolución del duelo. Además, se revisaron diferentes fuentes teóricas de otros expertos en el campo para reforzar el propósito de cada una de las piezas.

Finalmente, este proceso se tradujo en 8 piezas organizadas de la siguiente manera:

Pieza 1: Una linterna de papel. También conocida como lámpara volante o farolito chino, es una especie de globo elaborado de papel de seda con un armazón circular de metal o carrizo en la parte inferior de la linterna que contiene una mecha con alguna sustancia aceitosa como parafina o glicerina que permitirá encender una llama de fuego que llenará de aire caliente el interior de la linterna, haciendo que esta se eleve en el cielo y permanezca flotando el tiempo que la llama esté encendida.

Esta linterna se encontrará doblada dentro de la caja y al momento de desplegarse alcanzará una altura de $103 \mathrm{~cm}$ aproximadamente. En ella estará escrito el nombre de la persona fallecida junto con una dedicatoria y servirá para rendirle un homenaje de despedida, ya que al no estar permitido el manifiesto de los símbolos funerarios es importante realizar ceremonias conmemorativas con el mismo significado con el objetivo de cerrar ciclos y reconocer la pérdida.

Esta pieza es $100 \%$ biodegradable, esta hecha de papel de arroz y bambú y es resistente al fuego para evitar cualquier riesgo de incendio. Además su composición está libre de metal. Pieza 2: 2 Papeles para escribir cartas. La escritura ayuda mucho a exteriorizar sentimientos, por eso, la redacción de una carta ayuda a expresar pensamientos, ideas, despedirse o incluso reconciliar o solucionar algo pendiente entre el doliente y el fallecido. Es una forma de despedida y liberación de emociones honestas, ya que muchas veces ante los ojos de los demás los dolientes indican estar bien y tranquilos, pero muy dentro de ellos aún no se han permitido vivir sus emociones plenamente (Worden,1997). 
La otra carta, está pensada para que las personas se escriban a sí mismas. Realizar este ejercicio íntimo les permitirá describir qué está pasando y cómo se sienten. Escribiendo en primera persona pueden encontrar un camino más directo hacia sus emociones, desahogándose y contándose a sí mismos todo lo que no quieren contar a los demás. Sin embargo, este ejercicio no termina ahí, también se pueden incluir mensajes al "Yo" del futuro, describiendo planes, metas y sueños que quieran lograr, de esta manera irán buscando inspiración en ellos mismos que les genere fortaleza para sobrellevar este difícil momento (Barbancho et al, 2020).

La hoja de la carta mide $18,5 \times 16,5 \mathrm{~cm}$, y tiene un diseño sencillo para que las personas puedan aprovechar en hacer uso del espacio. Asimismo, el material de la hoja es papel semilla plantable, un tipo de papel ecológico biodegradable que se caracteriza por tener semillas en su composición que son capaces de crecer al ser plantadas en la tierra.

Pieza 3: Un diario de duelo. Los beneficios de escribir también se desarrollan a través del diario. Durante las terapias, los especialistas (Worden, 1997) recomiendan al doliente empezar a redactar un diario desde su primera sesión hasta la última, para que tengan la posibilidad de autoevaluar su progreso. Manejar esta técnica desde casa puede ser muy beneficiosa; ya que a través de ella encuentran la posibilidad de reflexionar y reducir el sentimiento de soledad. En el pueden redactar recuerdos, historias, intuiciones, esperanzas y preguntas que vayan teniendo a lo largo del proceso.

El diario tiene un tamaño A5, y consta de 50 hojas rayadas. En su interior se incluirán mensajes y frases reconfortantes que irán acompañando la dinámica de la escritura. Además tendrá 10 hojas en blanco al final para que puedan hacer dibujos, ya que esta herramienta, así como la escritura ayuda a exteriorizar emociones y darles una forma visual (Worden, 1997).

Pieza 4: 3 velas pequeñas. El objetivo de las velas es que puedan ser usadas en los momentos donde surja el recuerdo del fallecido o la necesidad espiritual de comunicarse 
con su memoria. Serán útiles cuando surjan emociones fuertes, se extrañe o se piense mucho en el fallecido.

Son velas cilíndricas de 5,5 x 4,7 aproximadamente y al prenderse desprender un aroma a rosa, lavanda y jazmín. Cada una tiene mensajes alrededor como: "Te quiero y te extraño más que a nada", “Nunca te olvidaré”, "Gracias por todo”, "Eres mi más bello recuerdo”y “Estás presente en mi corazón”.

Pieza 5: Un frasco de dulces. Se eligió este tipo de producto para poder estimular el estado de ánimo de la persona. Ingerir alimentos dulces estimula la serotonina y las endorfinas, que son las hormonas que producen sensación de felicidad y bienestar. Además regulan el sueño, el apetito y la sensibilidad al dolor. Cuando los niveles de serotonina se encuentran bajos se expresa a través de malestar emocional; por ello es importante consumir alimentos ricos en triptófano, el aminoácido encargado de producir serotonina en el cuerpo (Prat, 2017).

Este es un frasco de vidrio pequeño de $210 \mathrm{ml}$ aproximadamente, y posee $6,9 \mathrm{~cm}$ de diámetro y 7,3 cm de alto. Se eligió al chocolate como elemento predeterminado pues el cacao y el azúcar son gran estímulo para aumentar el nivel de serotonina; sin embargo, también puede ser reemplazado por galletas, caramelos frutados o en su defecto, por frutos secos (nueces, pecanas, pasas, almendras) o incluso un yogur natural; ya que también son alimentos que predisponen al organismo a una mejor absorción de triptófano, aumentando la sensación de bienestar (Universidad de Alicante, s.f.).

Pieza 6: Un portaretratos. Usar símbolos como fotografías, ayuda a crear un nuevo recuerdo del fallecido. Realizar un altar en casa o simplemente tener un recuerdo fotográfico en algún lugar especial, permite a las personas recordar las experiencias vividas con él. Sin embargo, esta herramienta no obliga al doliente a poner una fotografía del fallecido de forma inmediata. Dependerá mucho de la persona. Algunas de ellas se sienten muy susceptibles ante una foto y prefieren evitarlas pues le causa más tristeza; sin embargo, para otros es reconfortante poder ver a su ser querido en fotografías felices. 
Es importante desarrollar el duelo hasta poder ser capaces de enfrentar una imagen del fallecido sin que esta genere gran dolor. Poder controlar las emociones ante este estímulo y usarlo como una herramienta constructiva es una señal de que el duelo está evolucionando de manera positiva.

El portarretratos tiene una medida de $15 \times 10 \mathrm{~cm}$ y está hecho de madera color natural que incluye un print que podrá ser retirado cuando el doliente se sienta listo de cambiarlo por una fotografía.

Pieza 7: Manual de instrucciones. Este es un manual pequeño con medida de $15 \times 20 \mathrm{~cm}$ para facilitar la lectura, que indicará el propósito de cada pieza y también contendrá algunos consejos y recomendaciones para poder sobrellevar el duelo adecuadamente. Además, en la contraportada se agregó una sección con el número o números telefónicos del remitente para que el doliente se sienta libre de poder entablar comunicación con ellos para recibir apoyo moral.

Pieza 8: La caja. Es el contenedor de todas las piezas antes descritas. Servirá para que cada una de ellas lleguen en buen estado a su destino y además, cuando sus elementos hayan sido utilizados, podrá ser usada como una caja de recuerdos para el doliente y su familia, donde podrán guardar algún objeto personal del fallecido, fotografías, algún texto redactado por el difunto, o cualquier estímulo que les permita recordar a esta persona con la misma felicidad con la que vivió.

No es necesario hacer uso de las piezas en el orden previamente descrito, pues el duelo es un proceso individual que dependerá de la personalidad y contexto de cada persona, por ende, tienen la libertad de usarlas acorde a la necesidad que estén atravesando. También, como se aprecia en las descripciones, cada pieza podrá ser personalizada especialmente para cada caso. Además el hecho de que el paquete deba ser enviado por alguien más, aporta el mensaje de que esta persona no está sola, que hay gente que se preocupa por ella y quiere darle el apoyo que necesite para que atraviese esa situación y vuelva a ser feliz. Por otro lado, la estructura del producto permite añadir otros objetos que el remitente 
quiera enviar, una dedicatoria, fotografías pequeñas impresas, o algún objeto que responda a características más específicas del doliente como un rosario, alguna estampita religiosa, bolsitas de té relajante, agua de azahar, etc.

Cabe resaltar que la preparación de las cajas no se tercerizará para poder mantener el control de que todas las piezas se empaquen de manera compacta y con la higiene necesaria para que no exista riesgo aluno de contagio. Además, dentro del proceso de empaquetado se usará papel Kraft para proteger y mantener en su lugar cada pieza. Este material es $100 \%$ renovable, biodegradable y reciclable.

Una vez elegidos los elementos se procedió a hacer el diseño de cada uno de ellos, así como también de su contenedor, etiquetas, brochure de instrucciones, empaques, etc. Después del proceso de diseño, se procedió a revisar cuánto sería la inversión para realizar 100 unidades de producto. Después de investigar precios al por mayor, se concluyó que el costo para fabricar 1 unidad es de S/. 76.40 lo que da la posibilidad de ofrecerlo al mercado con un precio aproximado de $\mathrm{S} / .100 .00$, precio que dentro del mercado de las "cajas regalo" es bastante atractivo y accesible para el público.

Para la elección de los mensajes que transmite el producto se evitó hacer uso de algunas frases que comúnmente se utilizan para consolar a los dolientes; ya que profesionales de la salud mental (Díaz et al, 2014), indican que no son beneficiosas para el desarrollo del duelo. Algunos de ellos son:

"El tiempo lo cura todo". Esta frase pone al doliente como un agente pasivo incapaz de controlar su entorno y que por eso debe esperar a que las cosas sucedan por sí solas. Una persona en duelo que recibe este mensaje siente que no tiene control de nada y solo desea que el dolor desaparezca como arte de magia, cuando en realidad el factor tiempo es el que se encarga de marcar el espacio entre el doliente y el fallecido y ayudarlo a observar el panorama desde otra perspectiva. El tiempo no resuelve el duelo, sino lo que el doliente haga con el. 
“A él/ella no le gustaría verte sufriendo". Esta expresión causa dos reacciones, la primera es que hace más complicado para el doliente aceptar la muerte, pues tiende a pensar que la persona fallecida aún está de alguna forma presente, mientras que la segunda, es que lo hace bloquear sus emociones por temor a ser visto o causarle dolor a un ser querido que en su mente aún lo contempla desde algún plano sobrenatural.

"No pienses en ello, que es peor". Esta es una frase que demuestra poco tacto, aunque no sea intencional, y surge muchas veces cuando la persona no sabe qué decirle al doliente ante esta situación. Es seguro que el mensaje que se da entre líneas es decirle al doliente que evite pensar en ello para evitar sentimientos delicados y dolorosos; sin embargo, esto no es saludable, el doliente necesita pensar en ello para poder ordenar sus ideas para asimilar la situación y buscar la forma de superarlo.

"Deberías distraerte con otras cosas". Esta es otra expresión que invita a evitar el duelo y distraer falsamente las emociones negativas. De la amplia lista de ideas erróneas, esta es una de las más peligrosas, pues provoca un desbalance emocional muy fuerte causado por el bloqueo del dolor sumado con la falsa idea de felicidad o disfrute al intentar disfrazarlo sin éxito.

"Debes ser fuerte". Es muy frecuente escuchar esto y manifiesta la idea equivocada de que expresar las emociones es sinónimo de debilidad. La asimilación de esta idea dependerá de las ideas, creencias, cultura y personalidad del individuo. Por ejemplo, un varón que creció alimentado de ideas machistas que lo obligaban a no llorar para demostrar su hombría, posiblemente acepte este mensaje con normalidad, pero al final, degenerará por completo el proceso de duelo.

"No lo dejarás descansar en paz, mientras no lo superes". Esta idea vuelve a evocar la falsa presencia del fallecido y el temor al mismo, solamente desatará un fuerte sentimiento de culpa y sentirá que de alguna forma le hace daño al fallecido, aumentando sus niveles de frustración. 
"Los que estamos contigo necesitamos que estés bien". Aunque estas frases se dicen con la mejor intención de confortar y ayudar al doliente, siempre se debe considerar que este tipo de consejos solo aumentan la presión en su proceso. Una persona en duelo no debe tener como prioridad el bienestar de los demás durante este periodo, sino el suyo propio, para que así pueda volver a funcionar dentro de su entorno social y responder emocionalmente como solía hacerlo antes de la pérdida.

\section{Relación entre Problema, Público Objetivo y Proyecto.}

Para mucha gente, intentar reconfortar a una persona en duelo en el contexto de la pandemia, donde no se puede hacer más que una llamada o dejar un mensaje, es una tarea bastante difícil, ya sea por no poder encontrar las palabras adecuadas o no poder brindar la cercanía de un abrazo. Sin embargo, la mejor ayuda que se puede dar en estos casos se da a través de gestos de cariño. Una persona en duelo tiende a aislarse y suele permanecer muy ensimismada durante este proceso y muchas veces no se mostrará receptiva a los estímulos que pueda recibir de terceros, es por esto la mayor parte del duelo la vivirá cuando tenga privacidad y tiempo con ella misma. Es por este motivo que la idea de un producto de ayuda en duelo es una buena herramienta personal que podrá ser enviada a todas las personas que estén atravesando esta situación, para que puedan descubrirla y usarla poco a poco con el objetivo de ordenar sus emociones y vivir el duelo sin ninguna complicación hasta poder resolverlo y elaborar un recuerdo saludable.

\section{Marca del Proyecto.}

El proyecto fue nombrado "Abrazo en caja"; ya que el abrazo es uno de los gestos más especiales para demostrar cariño y consuelo sin decir una sola palabra. Al estrechar a una persona en brazos, se manifiesta el deseo de proteger, dar tranquilidad y apoyar, transmitiendo energía y soporte. Sin embargo ¿Cómo poder transmitir lo bello de un abrazo en tiempos donde el mismo representa un riesgo para la salud? Metiéndolo en una caja. Toda la intención del abrazo cabe en esta caja llena de herramientas estimulantes y reconfortantes que servirán de ayuda para los que están sufriendo un gran dolor. Recibir 
esta caja significa recibir el abrazo de los vivos, y abrazar el recuerdo de los que ya no están, dándoles a cada uno un lugar en la mente y en corazón.

\section{Resultado.}
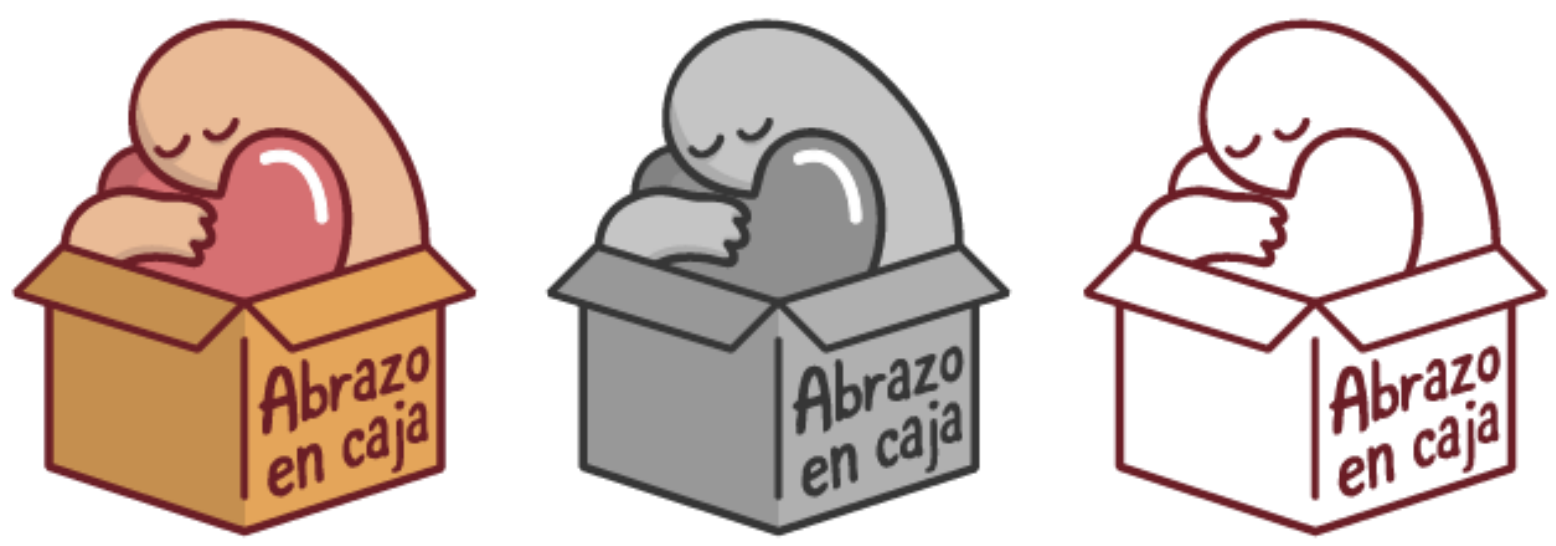

Figura 6 Logotipo de la marca. Fuente propia.

\section{Diseño de la Comunicación.}

El mensaje que se quiere dar al público objetivo es que aquel recuerdo que hoy les causa tanta tristeza, mañana será reconocido como parte de la vida y lo usará como inspiración para seguir viviendo, disfrutando y cuidando de los demás tanto como a sí mismos. Este será transmitido en las distintas piezas donde están incluidas frases y consejos que motivarán al usuario a continuar con una vida que aún tiene mucho por delante.

Es importante comunicar esto, ya que debido a los acontecimientos sanitarios actuales la gente que pierde a un ser querido por COVID-19 se ve obligada a omitir pasos importantes de duelo, trayendo como consecuencia grandes niveles de dolor, remordimiento y estrés que complican el proceso de duelo, por esto es vital ayudarlos a hacer más fácil este proceso.

El uso del lenguaje es muy importante a la hora de comunicar este tipo de contenido; ya que ser muy directo con frases como "Él/Ella murió" pueden ser bastante duras de asimilar por el doliente. Es mejor tratar las palabras con sutileza que indiquen la pérdida como “él/ella era" o "él/ella vivía”, con la intención de ayudar al doliente a aceptar su nueva realidad en torno a la pérdida y hacer que afloren sus emociones (Worden, 1997). Además, 
es muy importante manejar el tono adecuado, en especial en estos casos donde por más difícil que sea el manejo de este tipo de información, si enviamos el mensaje con un tono correcto podremos ayudar a amortiguar el dolor que puedan estar atravesando.

Por otro lado, se planteó dar a conocer el producto mediante las redes sociales Facebook e Instagram a través de una campaña de intriga de aproximadamente semana y media para atraer la atención de la audiencia. Después se realizó una transmisión en vivo donde un especialista en psicología presentó el producto y sus piezas, indicando cómo se usan y para qué sirve cada una de ellas. Además, se creó un espacio en redes sociales para que la gente que haya enviado o recibido un "Abrazo en caja” pueda contar su experiencia y qué le pareció, si le sirvió de ayuda o no.

El mensaje perdurará en el tiempo gracias a una etapa de mantenimiento en redes sociales, donde se publicarán consejos y tips para encaminar un duelo sano, dándole así a la comunidad un espacio para poder compartir sus casos e intercambiar ideas mientras se estimulan con contenido de calidad.

\section{Piezas Empleadas.}

Se diseñó una serie de personajes basados en el logotipo que finalmente se usaron en las 8 piezas previamente explicadas, obteniendo los siguientes resultados.
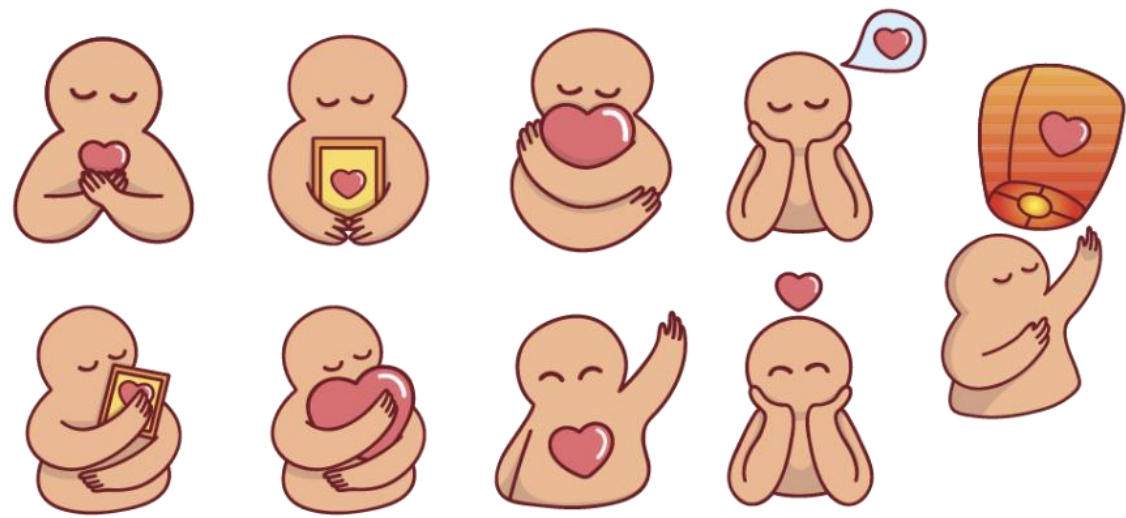

Figura 7 Personajes. Fuente propia. 


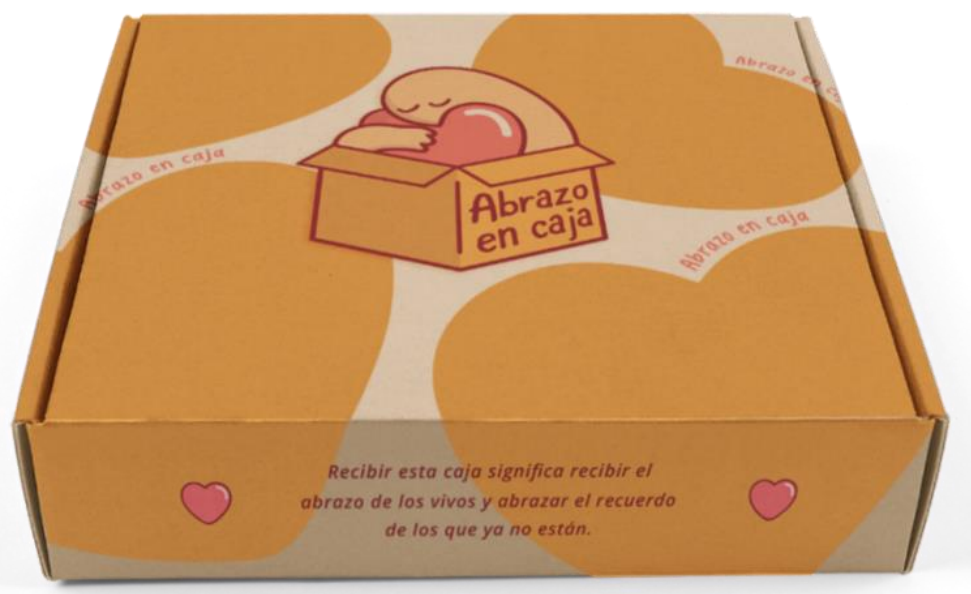

Figura 8 Caja del producto. Fuente propia.
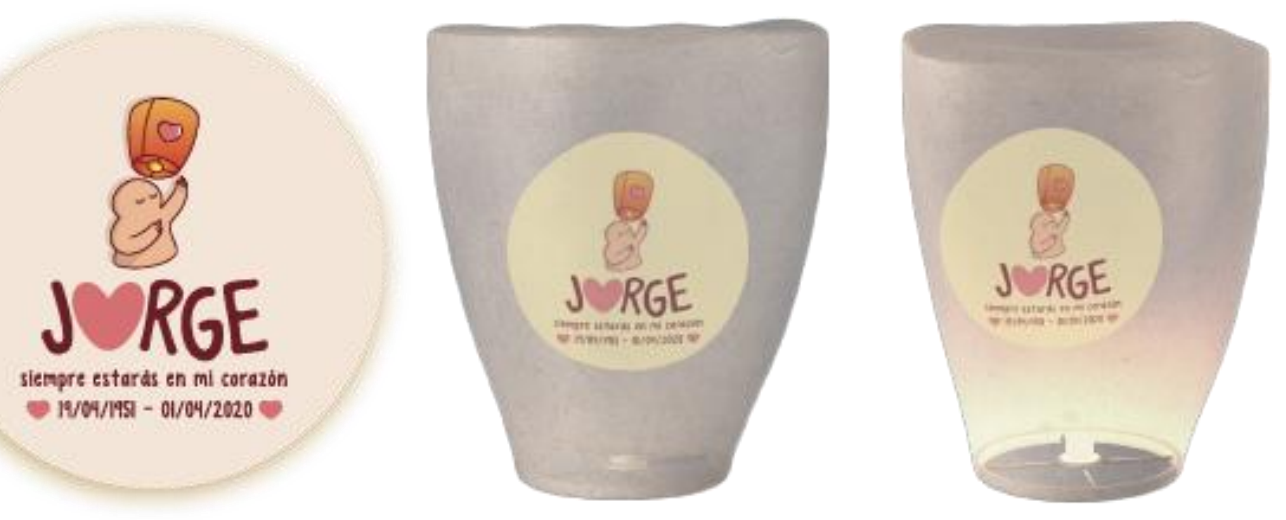

Figura 9 Linterna de papel. Fuente propia.

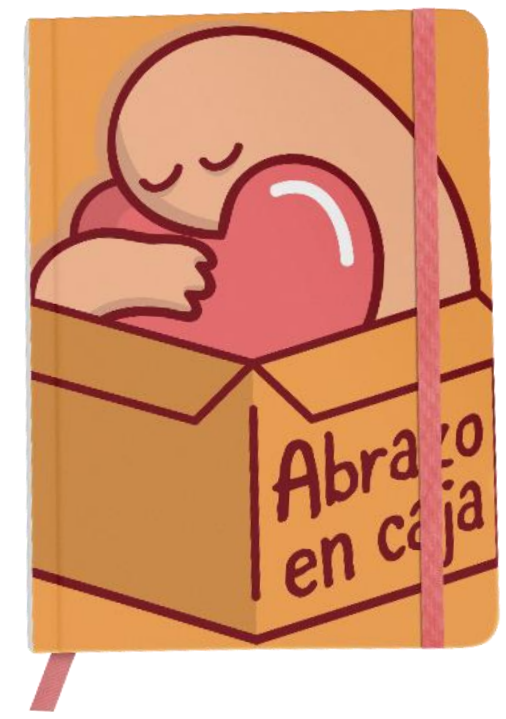

Figura 10 Diario de duelo. Fuente propia. 


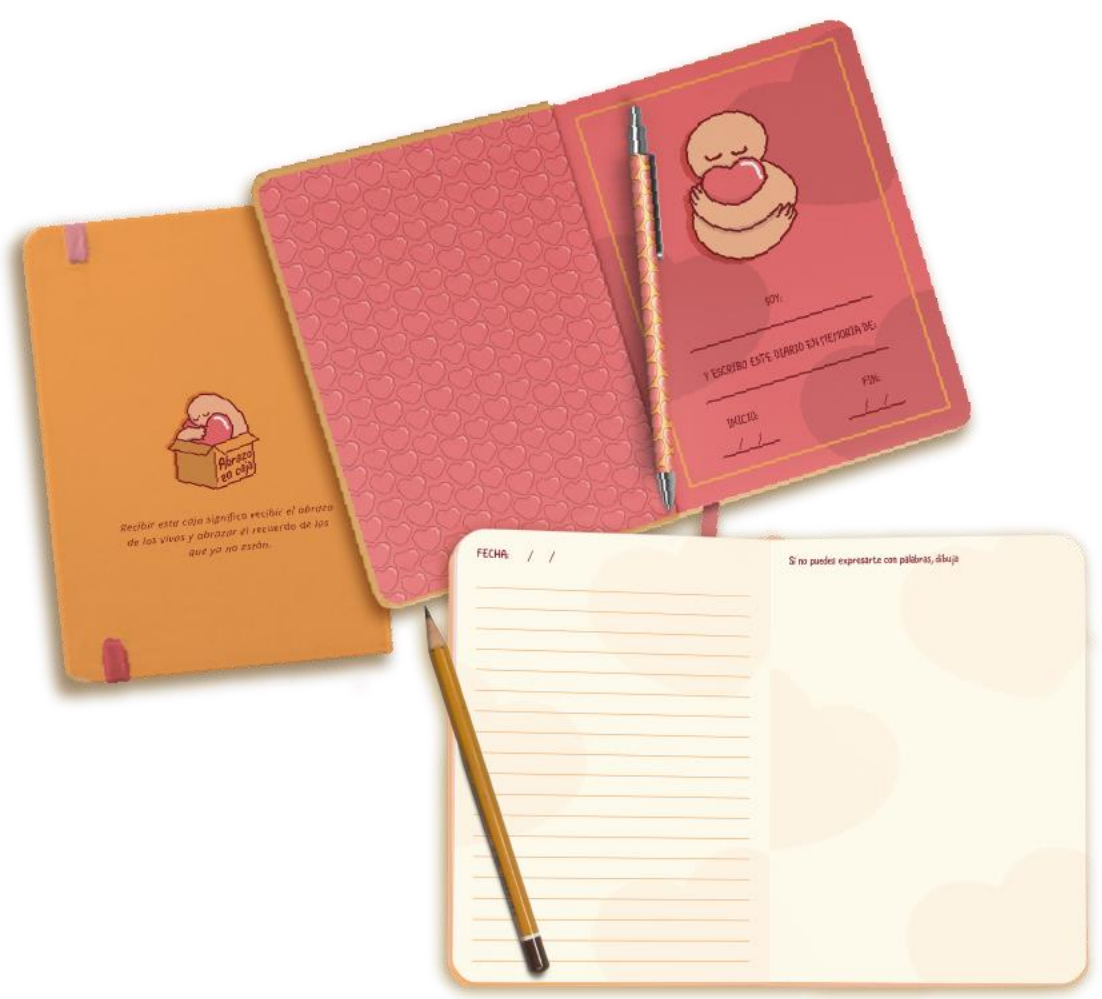

Figura 11 Diario de duelo interiores. Fuente propia.
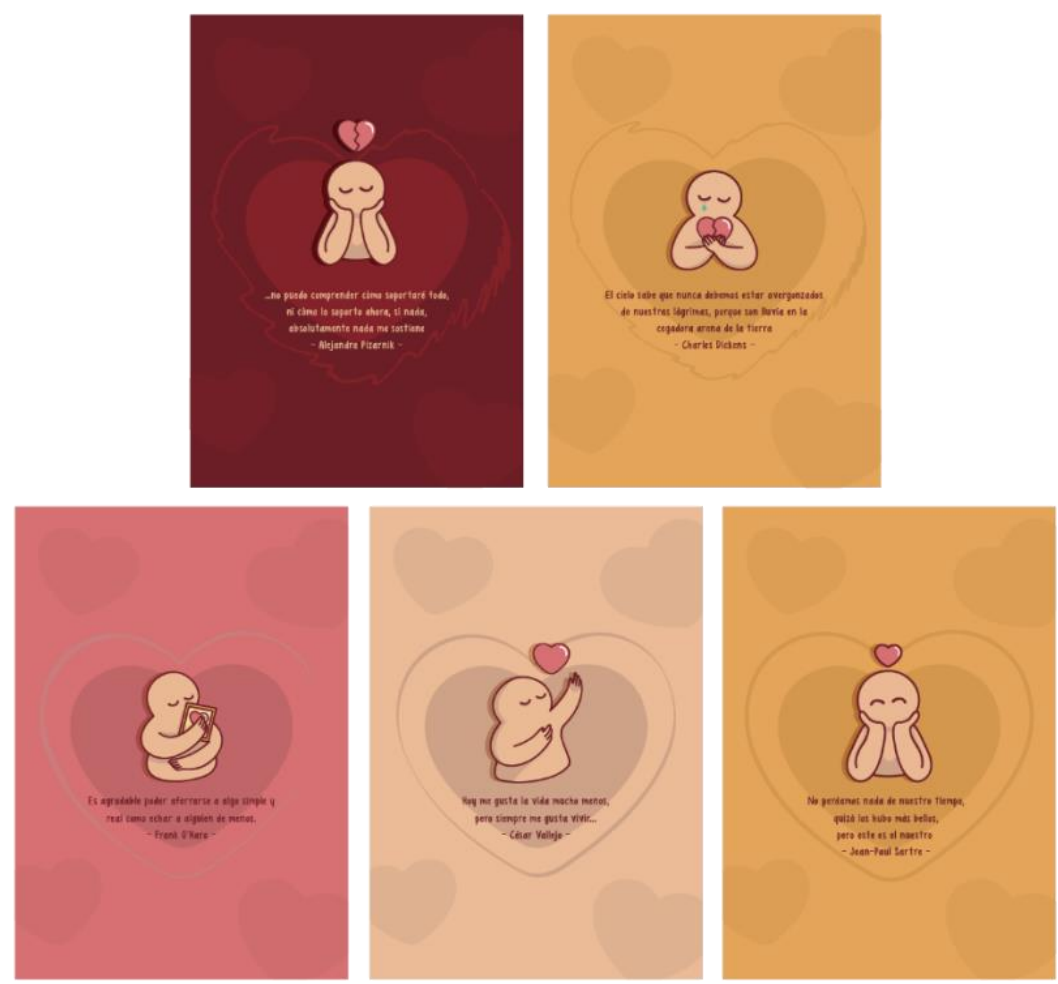

Figura 12 Frases interiores del diario. Fuente propia. 


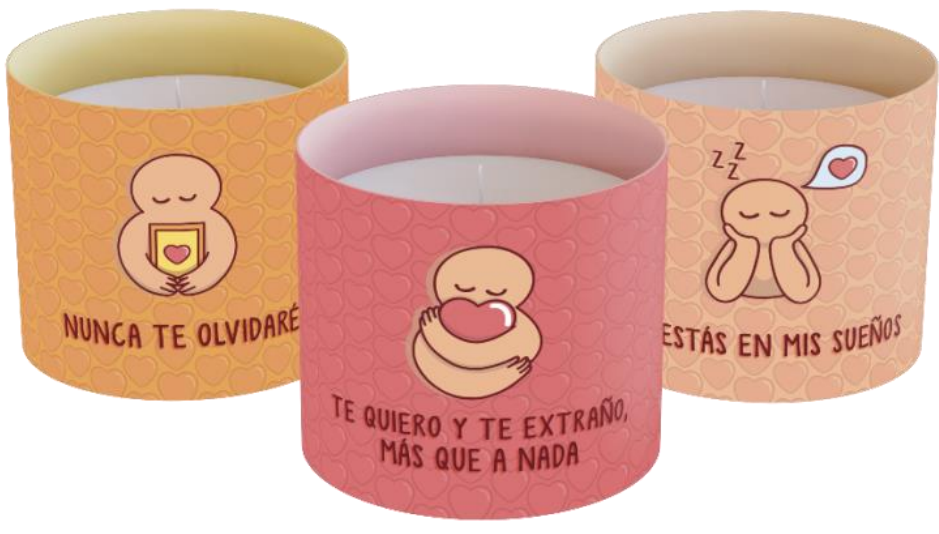

Figura 13 Diseño de velas. Fuente propia.
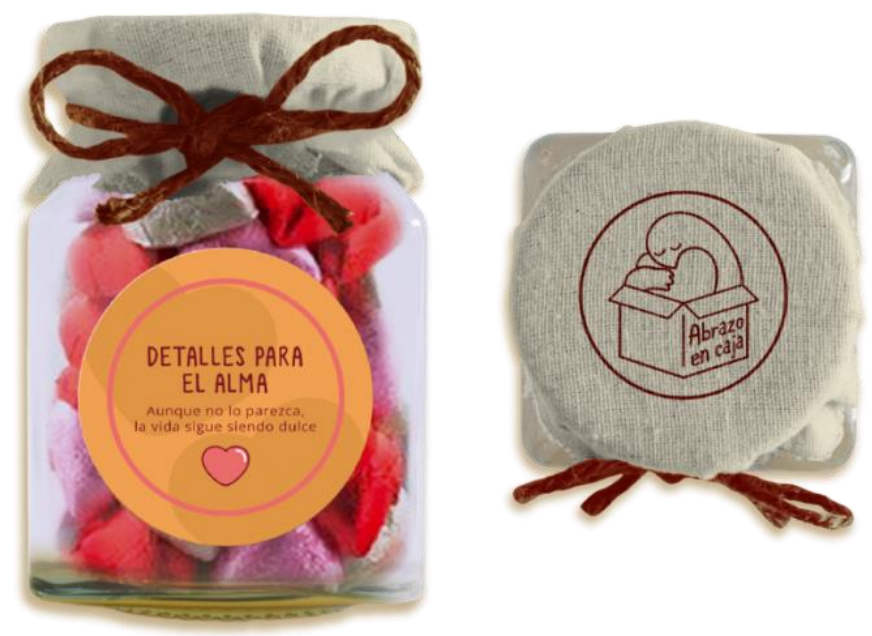

Figura 14 Frasco de dulces. Fuente propia.

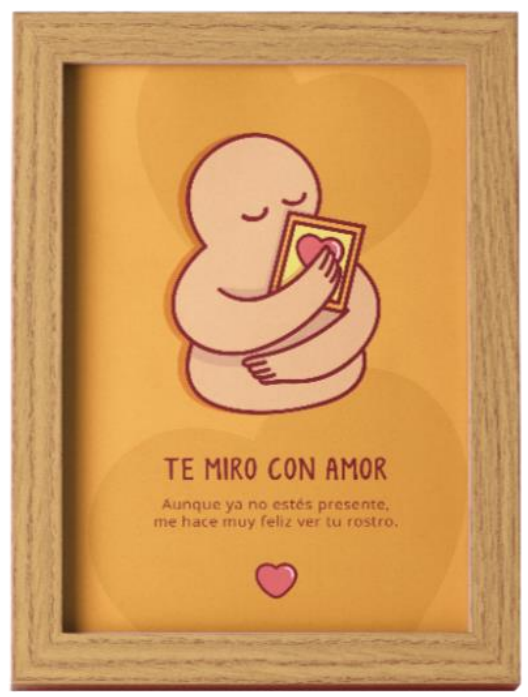

Figura 15 Portaretratos. Fuente propia. 


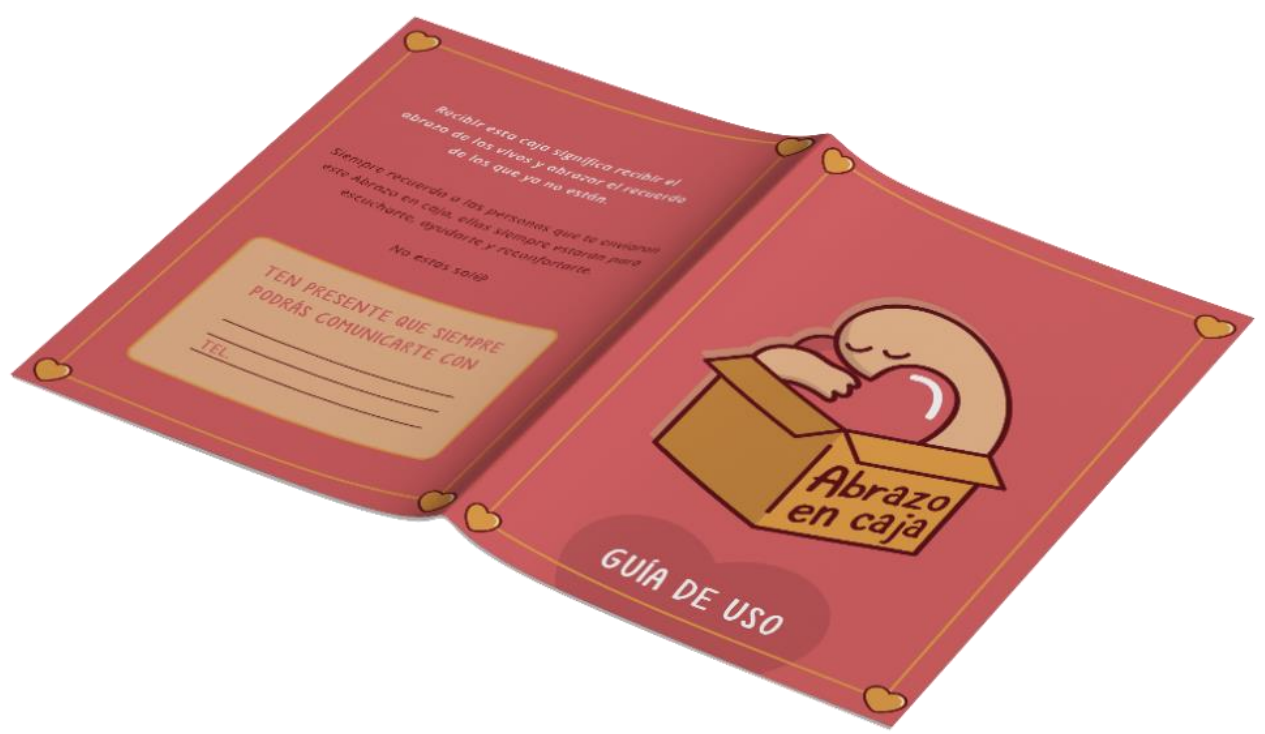

Figura 16 Manual de instrucciones. Fuente propia.

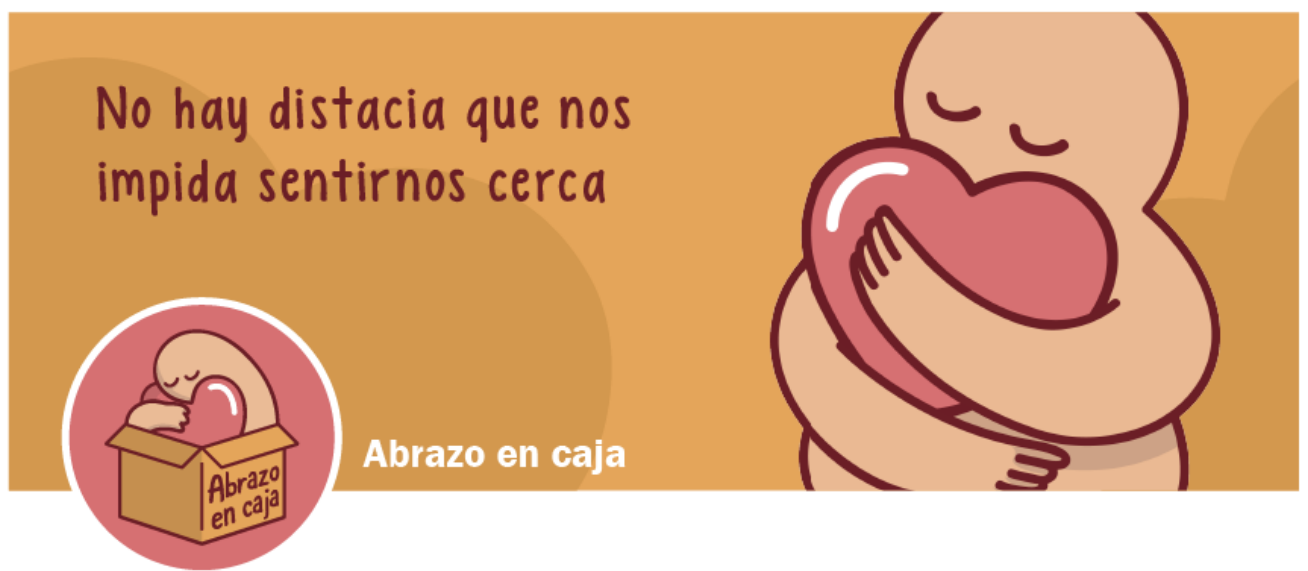

Figura 17 Portada y foto de perfil de Facebook. Fuente propia.

\section{Reflexiones.}

Gracias a la investigación e interacción con diversas personas ubicadas en el contexto del problema se pudo plantear un proyecto de diseño muy completo. Este funciona como una terapia sutil para los dolientes adultos, quienes tienden a contener sus sentimientos abiertamente por temor de afectar el ambiente familiar y además no consideran el apoyo psicológico profesional como algo necesario. Es por eso esto que dándoles esta opción para desarrollar el duelo de manera independiente, que además les da la libertad de interactuar a su propio ritmo con cada pieza, ayudará de manera significativa a la resolución del duelo. 
El producto tiene la facilidad de distribuirse en Lima Metropolitana, pero también puede distribuirse a nivel nacional y posteriormente en el extranjero.

“Abrazo en caja" posee un gran potencial, ya que es muy versátil, no solo por la característica de personalización que le permite adaptarse a aspectos más específicos de los dolientes, sino que a futuro puede servir de ayuda para otros tipos de pérdidas como por ejemplo: Despedir a un amigo que se muda o se va lejos, acompañar a los padres durante el proceso de independización de los hijos, un proceso de divorcio, durante el desarrollo de una enfermedad, entre otras situaciones. Demostrando así que puede adaptarse a distintos contextos y públicos objetivos.

Por otro lado, este producto es capaz de generar un efecto cadena, es decir, si algún usuario de "Abrazo en caja” vivió una experiencia grata con el producto, cuando alguien en su entorno se encuentre en una situación similar, pensará en brindarle el mismo estímulo.

Algo que atrae mucho sobre el proyecto es su valor agregado como producto eco amigable, que hoy en día es muy apreciado por distintas generaciones, convirtiéndolo en un producto consciente que no solo se preocupa por generar bienestar en las personas sino también en el medio ambiente.

Lo más gratificante de realizar este proyecto es poder ver que las personas lo perciben como un producto novedoso, útil y pensado para generar un aporte a uno de los campos más descuidados por las autoridades de nuestro país: La salud mental. Sería muy agradable lograr que este producto, más que una idea de negocio, pueda trabajarse de la mano con distintas entidades preocupadas por el bienestar de las personas más afectadas.

\section{Conclusiones.}

El proyecto es empático y solidario con las personas, llega a transmitir el mensaje y es muy probable que ayude a las personas a manifestar y manejar sus emociones para que puedan resolver el duelo sin que se desarrolle la patología.

El producto es seguro para poder desarrollarse durante esta etapa de pandemia; ya que gracias a sus características puede ser empacado y enviado con especial cuidado 
respetando los protocolos de seguridad sanitaria, evitando que se convierta en un transmisor del virus.

El proyecto es completo y está bien pensado, no solo tiene herramientas terapéuticas eficientes avaladas por profesionales en la salud mental, sino que también, tiene especial planificación en que cada elemento tenga una razón de ser y no represente un riesgo para el medio ambiente.

Llama la atención por ser único y una bonita manifestación de condolencia.

El precio es accesible y responde al valor agregado que posee el producto, llegando a ser percibido como "económico" para todo el beneficio que se consigue a cambio.

Se recomienda que cuando se dé a conocer el producto, se pueda brindar el producto a un pequeño grupo de personas voluntarias, para hacer seguimiento de cómo evoluciona el proceso de duelo para comprobar definitivamente su efectividad.

Se recomienda poder investigar más a profundidad al público objetivo y relacionarse más con el estilo de vida que llevan.

\section{Referencias Bibliográficas.}

Acinas, P. (2012). Duelo en situaciones especiales: suicidio, desaparecidos, muerte traumática. Revista Digital Médica y Psicosomática, 2, 1-17.

Agnew, A., Manktelow, R., Taylor, B., Jones, L. (2010). Bereavement needs assessment in specialist palliative care: a review of the literature. Palliat Med., 24(1):46-59.

Alarcón et al, E. (2020). Guía para las personas que sufren una pérdida en tiempo del coronavirus. Recuperado de: http://www.ipirduelo.com/wp-content/uploads/GUI\%CC\%81ADUELO-COVID19-2020.pdf

Ambrose, G. \& Harris, P. (2011). Packaging the Brand: The relationship between packaging design and brand identity. Lausanne: Ava Publishing S.A. 
Aranda, S. \& Milne, D. (2000) Guidelines for the Assessment of Complicated Bereavement Risk in Family Members of People Receiving Palliative Care. Melbourne: Centre for Palliative Care.

Barbancho, M., Jiménez, A., Silva, A \& Vialás, L. (2020) COVID-19: Guía para familiares en duelo. Sevilla: Colegio Oficial de Psicología de Andalucía Occidental.

Barreto, M. \& Soler, M. (2004). Apoyo psicológico en el sufrimiento causado por las pérdidas: el duelo. En Bayés, R. (Eds.). Monografías Humanitas 2: Dolor y Sufrimiento en la Práctica Clínica. Barcelona: Fundación Medicina y Humanidades Médicas.

Cabodevilla, I. (2007). Las pérdidas y sus duelos. Anales del sistema sanitario de Navarra, 30, 163-176.

Calver, G. (2004). ¿Qué es el packaging? Barcelona: Editorial Gustavo Gili, S.L.

Cassem, N. (1975). Bereavement as indispensable for growth. En Sehoenberg, B., Gerber, J., Wiener, A., Kutseher, A., Peretz, D. \& Carr, A. (Eds.), Bereavement: Its psychosocial aspects (pp. 9-17). New York: Columbia University Press.

Colegio Oficial de Psicología de Madrid. (2020, 24 de Abril) El Adiós Sin Abrazos. Guía de apoyo psicológico a personas que han perdido a un familiar a consecuencia del coronavirus [COPMadrid.org] Recuperado de:

https://www.copmadrid.org/web/comunicacion/noticias/1513/el-adios-abrazos-guia-apoyopsicologico-personas-que-han-perdido-un-familiar-consecuencia-coronavirus

Centros para el Control y la Prevención de Enfermedades. (2020, 11 de Junio) Cómo reducir el estigma asociado al COVID-19. . Recuperado de: https://espanol.cdc.gov/coronavirus/2019ncov/daily-life-coping/reducing-stigma.html

Decreto Supremo N 116-2020-PCM. (2020). Decreto supremo que establece las medidas que debe observar la ciudadanía en la Nueva Convivencia Social y prorroga el Estado de Emergencia Nacional por las graves circunstancias que afectan la vida de la Nación a 
consecuencia del COVID-19. El peruano. Recuperado de:

https://www.pj.gob.pe/wps/wcm/connect/b4d321804ed4e619aa1faae589e1d483/ds116.pdf?M

OD=AJPERES\&CACHEID=b4d321804ed4e619aa1 faae589e1d483

Díaz, P., Losantos, S. \& Pastor, P. (2014). Guía del duelo adulto para profesionales sociosanitarios. Madrid: Fundación Mario Losantos del Campo

Directiva sanitaria Nº 087 -2020-digesa/Minsa Directiva Sanitaria Para El Manejo De Cadáveres Por Covid-19, Ministerio de Salud, Perú

Echeburúa, E. \& Herrán, A. (2007). Cuando el duelo es patológico y cómo hay que tratarlo. Análisis y Modificación de conducta, 33(147), 38-46.

Echeburúa, E. (2004). Superar un trauma: el tratamiento de las víctimas de sucesos violentos. Madrid: Pirámide.

Estevan, P. (2017). Validación y adaptación transcultural del cuestionario prolonged grief PG-13 para la detección precoz del duelo prolongado (Tesis doctoral). Universidad Complutense de Madrid Departamento de medicina, Madrid.

Estrategias Ecoeficientes. (2015). Ecodiseño. Recuperado de: https://ecodisenocba.wixsite.com/ecodisenocba/estrategias-generales

FISHEL, C. El arte de la producción creativa, materiales, encuadernación y acabados, Barcelona: Indexbook, 2007

Frantz, T. (1984). Helping parents whose child has died. En Hansen, C. \& Frantz, T. (Eds.), Death and grief in the family (pp. 11-25). Roekville: Aspen.

Freud, S. (1917). Duelo y melancolía. Londres: Hogarth.

Funerarias y crematorios registran cifras históricas durante estado de emergencia por COVID19”. RPP Noticias. (2020, 10 de Junio). Recuperado de: 
https://rpp.pe/peru/actualidad/coronavirus-funerarias-y-crematorios-registran-cifrashistoricas-durante-estado-de-emergencia-por-covid-19-noticia-1271984?ref=rpp

Gamo, E. \& Pazos, P. (2009). El duelo y las etapas de la vida [versión electrónica]. Revista de la Asociación Española de Neuropsiquiatría, 29, 455-469

García, C. \& Yagüe, A. (1999). Duelo perinatal. Revista de enfermería. 10. 17- 20.

García-Viniegras, C. \& Pérez, C. (2013). Duelo ante muerte por suicidio. Revista Habanera de Ciencias Médicas, 12(2), 265-274

Gerber, P., Barrett, J., Barrett, J., Oxman, T., Manheimer, E., Smith, R. \& Whiting, R. (1992). The relationship of presenting physical complaints to depressive symptoms in primary care patients. Journal of General Internal Medicine, 7(2).

Gloria, C. (2020).Diseño e innovación, la gestión del diseño en la empresa. Cotec. Recuperado de: https://es.calameo.com/books/001392177486c2be398aa

Guía Ecológica.(2015). Ecodiseño. Recuperado de:

https://ecodisenocba.wixsite.com/ecodisenocba/gu-a-ecol-gica-del-papel

Herrera, V. (2020). Entrevista por Andina, Agencia Peruana de Noticias. Recuperado de: https://andina.pe/agencia/noticia-como-despedirte-simbolicamente-tu-familiar-fallecidocoronavirus-791996.aspx

Ivañez, J. (2000). La gestión del diseño en la empresa. Recuperado de: http://biblio3.url.edu.gt/Libros/gestion/intro.pdf

Klerman, G., Dimascio, A., Weissman, M., Prusoff, B. \& Paykel, E. (1974) Treatment of depression by drugs and psychotherapy.131: 186-191. Recuperado de The American Journal of Psychiatry: https://ajp.psychiatryonline.org/doi/abs/10.1176/ajp.131.2.186

Kubler - Ross, E. (1975) Sobre la muerte y los moribundos. Barcelona: Grijalbo. 
Lafuente, M. (1996). La muerte y la familia. en Espina, A. \& Millán, M. (Eds.), Psicología de la familia: Un enfoque evolutivo y sistémico. Valencia: Promolibro.

Lang, U. \& Borgwardt, S. (2013). Molecular mechanisms of depression: perspectives on new treatment strategies. International Journal of Experimental Cellular Physiology, Biochemistry and Pharmacology, 31(6), 761-77

Lizarraga, S., Ayarra, M., Cabodevilla, I. (2005). Atención a la familia del paciente al final de la vida. Revista de Formación Médica Continuada en Atención Primaria, 12, 692-701.

Malone, L. (2007). Supporting people bereaved through homicide: Developing victim support's response. Bereavement Care Journal, 26(3), 51-53.

Mayo Clinic, (2017). Duelo Complicado [https://www.mayoclinic.org/es-es] Recuperado de: https://www.mayoclinic.org/es-es/diseasesconditions/complicated-grief/diagnosistreatment/drc-20360389

McDonough, W. and M. Braungart (2002). Cradle to cradle. Remaking the way we make things. New York, North Point Press

Moscoso, J. (2020). Apuntes para una política precaria del duelo en tiempos de covid-19, Hercritia. Recuperado de: https://www.catedradehermeneutica.org/wpcontent/uploads/2020/05/Moscoso-Cala-Javier-Apuntes-para-una-poli\%CC\%81tica-precariadel-duelo-Pandemia-Globalizacio\%CC\%81n-y-Ecologi\%CC\%81a.-Hercritia.pdf

Muñoz, M. (2014). Diseño de un empaque cíclico sostenible aplicado a una envoltura de regalo. (Tesis previa a la obtención del título de Diseñador Gráfico) . Recuperada de: http://dspace.ucuenca.edu.ec/handle/123456789/20959

Neimeyer, R. (2002). Aprender de la pérdida: Una guía para afrontar el duelo. Buenos Aires: Paidós.

Norman, Donald (2005).El Diseño Emocional. Por qué nos gustan (o no) los objetos cotidianos. Barcelona: Ed. Paidós 
Pariente, P. (2014). Handmade y el Diseño Gráfico. Recuperado de:

https://riunet.upv.es/bitstream/handle/10251/47456/memoria\%20paola\%20pariente.pdf?seque nce $=1$

Pérez, M. (1999). El proceso de duelo y la familia. En Astudillo, W., Arrieta, C., Mendinueta, C. \& Vega, I. (Eds.). La familia en la terminalidad. Bilbao: Sociedad Vasca de Cuidados Paliativos

Gestión (2020, 26 de Agosto). Perú pasa a ser el país con la mayor mortalidad del mundo por el COVID-19 . Recuperado de: https://gestion.pe/peru/peru-pasa-a-ser-el-pais-con-la-mayormortalidad-del-mundo-por-la-covid-19-noticia/?ref=gesr

Pinasco, S. (2020). Despedirse a la distancia. El Peruano. Recuperado el 7 de Agosto, 2020 de https://elperuano.pe/noticia-despedirse-a-distancia-100795.aspx

Poudevida, S. \& Castillo, A. (2020). El duelo ante la pérdida de un ser querido durante el estado de alarma por coronavirus [El blog de la fundación Pasqual Maragall]. Recuperado de: https://blog.fpmaragall.org/duelo-coronavirus

Coronavirus: afiliarte al Seguro Integral de Salud (SIS) por internet. (2020, 2 de septiembre). Recuperado de: https://www.gob.pe/8957-coronavirus-afiliarte-al-seguro-integral-de-saludsis-por-internet

Prant, A. (2017). ¿Antojos de dulce?, ¿cómo está tu hormona de la felicidad?. Recuperado de: https://www.nutricionybienestar.life/nutrete/antojos-de-dulce-como-esta-tu-hormona-de-lafelicidad/

Prigerson, H, Shear, M., Jacobs, S., Reynolds, C., Maciejewski, P., Davidson, J., Williams, J. (1999). Consensus criteria for traumatic grief. A

Prigerson, H., Horowitz, M., Jacobs, S., Parkes, C., Aslan M., Mardi, J. Selby, C. et al. (2009) Prolonged Grief Disorder: Psychometric Validation of Criteria Proposed for DSM-V and 
ICD-11. Recuperado de PLoS Med:

http://journals.plos.org/plosmedicine/article?id=10.1371/journal.pmed.10 00121

Rando, T. (1993). Treatment of complicated mourning. Champaign: Research Press.

Rosner, R. (2015). Prolonged grief: setting the research agenda. European Journal of Psychotraumatology, 6.

RT en Español (2020, 21 de junio) Familiares de víctimas del covid-19 encuentran consuelo en los retratos de un muralista [archivo de video]. Recuperado de: https://www.youtube.com/watch?v=87wntp_X4bI

Ruiz, J. \& Cano.J. (2002). Manual de psicoterapia cognitiva. Jaén: R\&C Editores.

(Ricard, 1987). Ricard, Andre: Diseño y calidad de vida; en Ricard Andre y otros (1987) Diseños, IMPIVA: Generalitat Valenciana, Valencia. Recuperado de: http://biblio3.url.edu.gt/Libros/gestion/1.pdf

Salud con lupa (2020, 1 de Julio). Averigua la cobertura de tu EPS o seguro de salud particular frente a la COVID-19. Saludconlupa . Recuperado de:

https://saludconlupa.com/noticias/averigua-la-cobertura-de-tu-eps-o-seguro-de-saludparticular-frente-la-covid-19/

Saravia, M. (2020). Entrevista para el diario La República. Recuperado de: https://larepublica.pe/sociedad/2020/08/24/coronavirus-peru-las-deudas-despues-del-duelo-lasalud-mental-tras-la-perdida-de-familiares-por-covid-19-y-las-deudas-en-clinicas/

Schiaffino, B. (2014). Pérdidas y duelos a lo largo de la vida (Tesina). Asociación Mexicana de Educación Continua y a Distancia. México D.F.

Somos pacientes, la comunidad de asociaciones de pacientes. (2015). Campaña para apoyar a los padres en el duelo por la pérdida de un hijo [https://www.somospacientes.com/] Recuperado de: https://www.somospacientes.com/noticias/asociaciones/campana-para-apoyar-a-lospadres-en-el-duelo-por-la-perdida-de-un-hijo/ 
(Universidad de Alicante, s.f.) Alimentos favorecedores de la producción de serotonina.

Recuperado de: https://web.ua.es/en/cae/documentos/p-psicoeducational/foods-that-produceserotonin.pdf

Vargas, G. (2007). Intervención Clínica Tanatológia: Enfoque Ético y Psicodinámico. México: Tech Palewi.

Vedia, V. (2016). Duelo patológico: Factores de riesgo y protección. Revista Digital de Medicina Psicosomática y Psicoterapia, 6, 14-20.

Worden, J. (1997). El tratamiento del duelo: Asesoramiento psicológico y terapia. Barcelona: Paidós

Yi, P. (2015). Duelo: Factores de riesgo de duelo complicado en cuidados paliativos. (Tesis doctoral) Universidad de Valencia Facultad de Psicología, Valencia.

Yoffe, L. (2006) Efectos positivos de la religión y la espiritualidad en el afrontamiento de duelos. Revista Psicodebate, Psicología, Cultura y Sociedad., 7, 193-205

\section{Anexos}

\section{Anexo 1.}

\section{Encuesta}

\section{Descripción de la encuesta}

- Actor: Dirigida a adultos de 35 años a más que vivan en el área de Lima Metropolitana.

- Objetivo: Conocer qué tanto está influyendo la coyuntura en el estilo de vida y cómo perciben la idea de la muerte en este contexto, para poder saber si están propensos a desarrollar un duelo patológico en el futuro.

- Muestra: 41 personas. 
Preguntas y respuestas

1. Edades

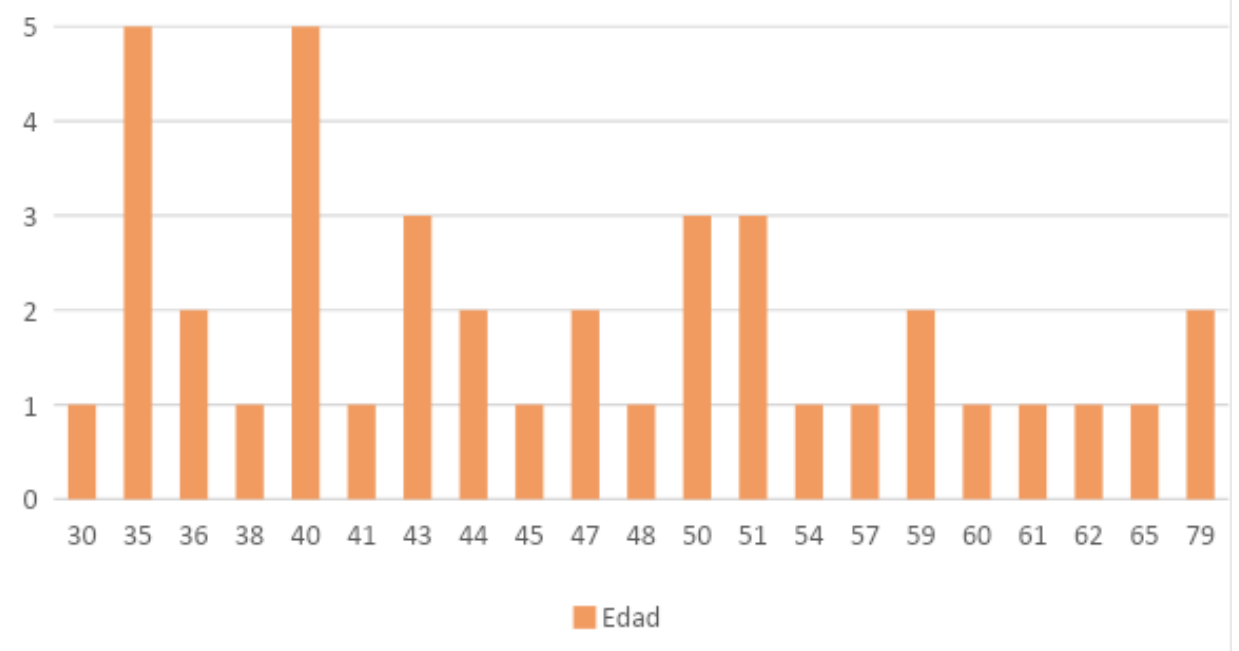

2. Sexo

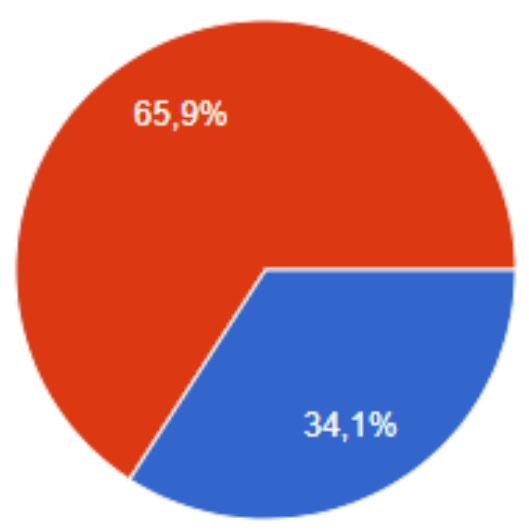

Masculino

Femenino

3. Estado civil

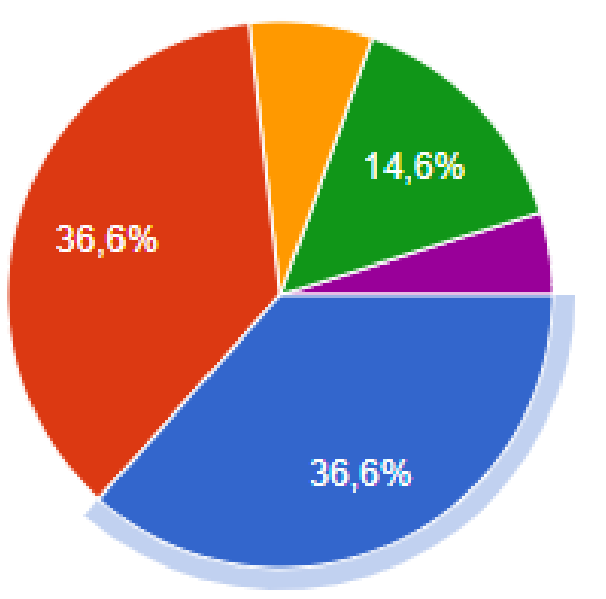

Soltero

- Casado

- Divorciado

- Conviviente

- Viudo 


\section{Lugar de residencia}

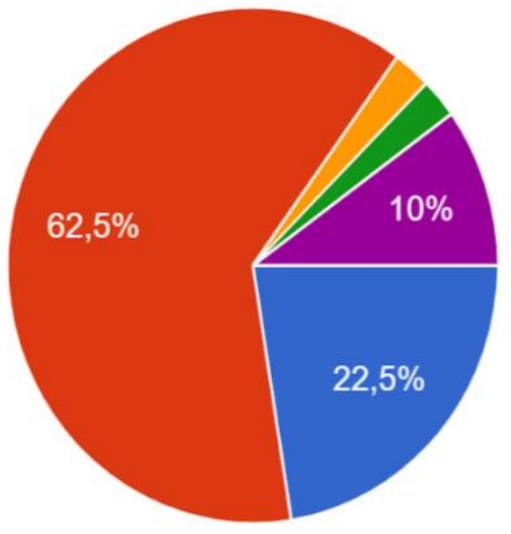

NORTE: Ancón, Pte. Piedra;

Sta. Rosa, Carabayllo, Comas...

ESTE: S. J. de Lurigancho, Sta. Anita, Cieneguilla, Ate Vitarte,...

SUR: S. J. de Miraflores, V.M. de Triunfo, Villa el Salvador, L...

CENTRAL: Cercado, San Luis, Breña, La Victoria, Rimac, Lin...

- CENTRAL SUR: Barranco, Mi...

BALNEARIOS DEL SUR: Pta....

\section{5. ¿Con quiénes vives en casa?}

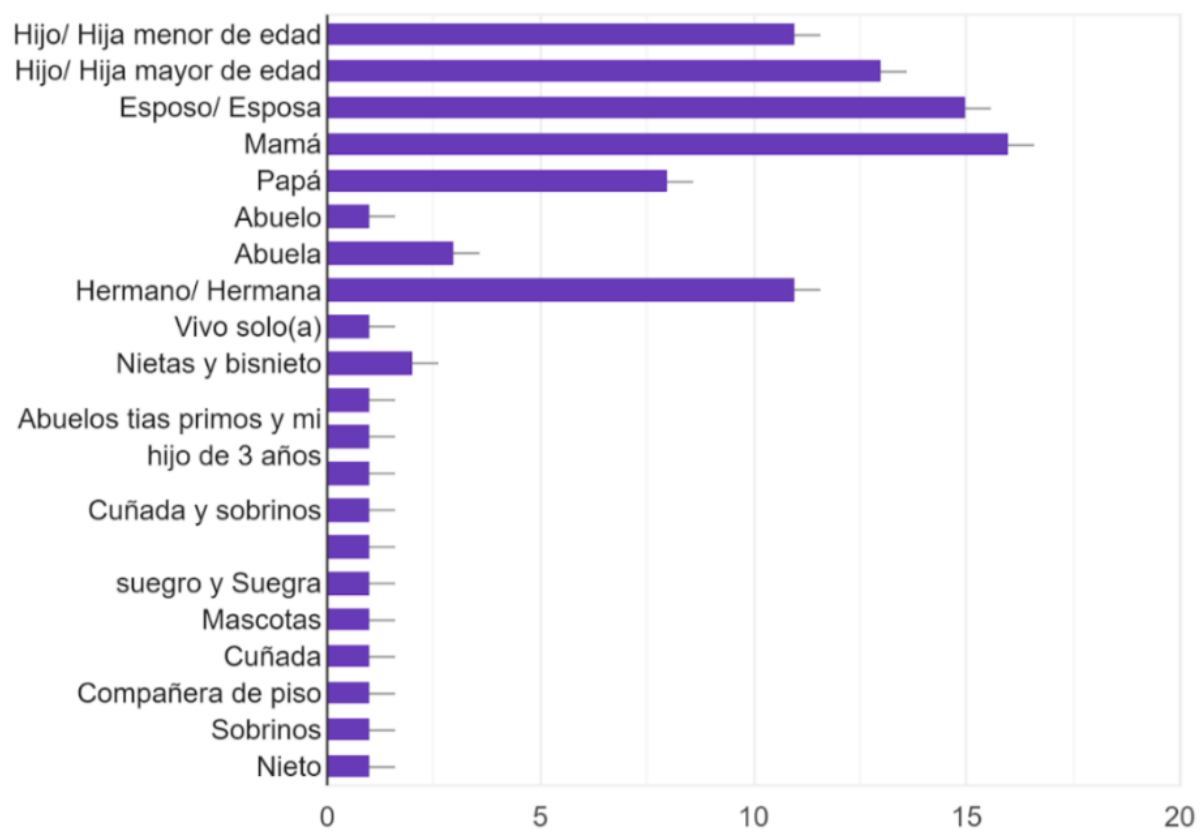

6. ¿Te encuentras trabajando en este momento?

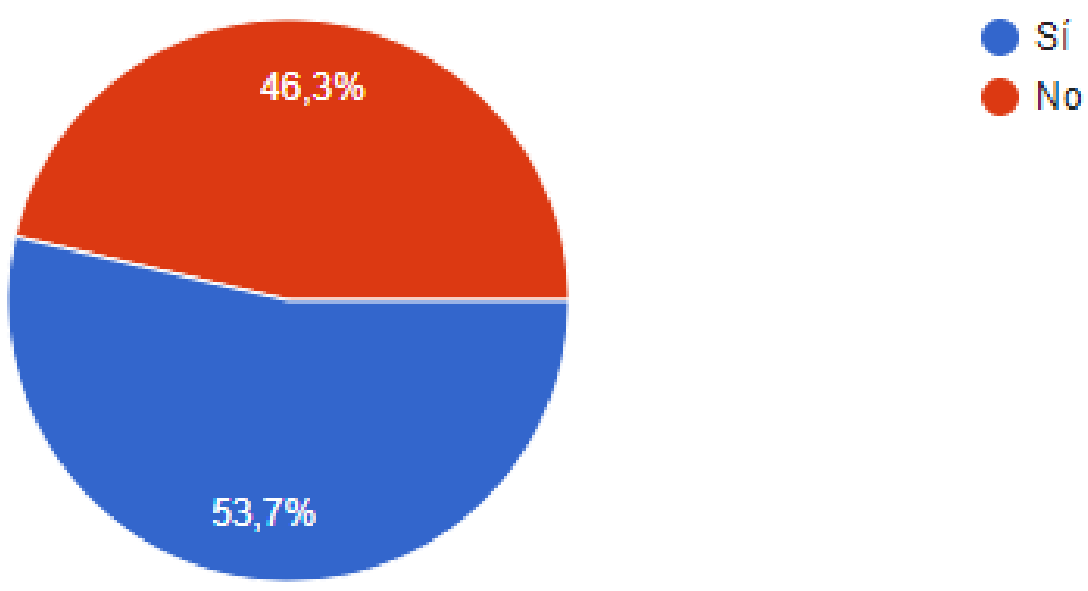


7. Si respondiste que sí a la pregunta anterior ¿En qué modalidad estás trabajando?

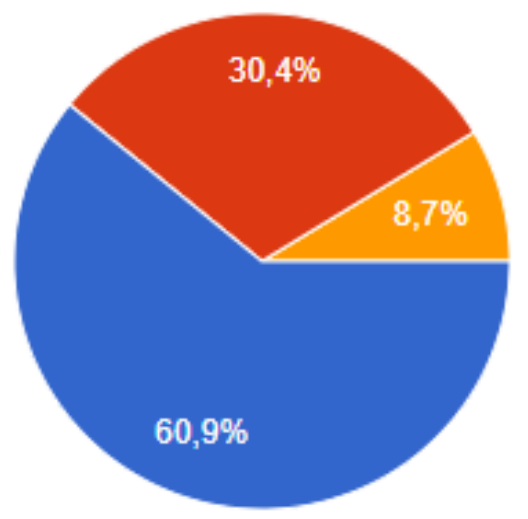

Desde casa

Presencial

Ambos

8. ¿Te costó adaptarte a las medidas sanitarias que se han estado dando a lo largo del año? (Cuarentena, uso de mascarilla, distanciamiento social, etc)

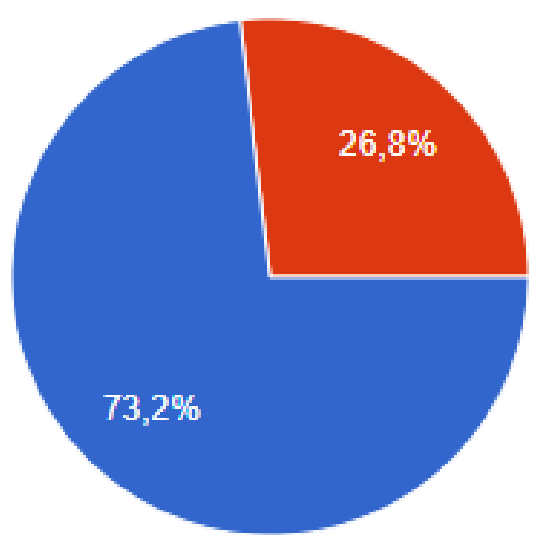

9. ¿Cuáles de las siguientes características reconoces en tu persona? Marca todas aquellas con las que te identifiques.

- Acepto apoyo, compañía y cuidado de otras personas de ser necesario. (23 respuestas)

- Resuelvo mis problemas por mi cuenta, para no preocupar a los demás. (22 respuestas)

- Tengo una autoestima sana. (21 respuestas)

- Acepto el fracaso y aprendo de el. (20 respuestas)

- Tiendo a ignorar situaciones problemáticas porque "la vida sigue" y no me puedo estancar en ellas. (15 respuestas)

- Antepongo el bienestar de los demás antes que el mío (15 respuestas) 
- Tengo metas y objetivos realistas. (19 respuestas)

- Si paso por un mal momento sé que es temporal. (24 respuestas)

- Entiendo que ocurren cosas malas de las cuales no tengo control. (20 respuestas)

- A veces me frustro o deprimo sin motivo aparente (8 respuestas)

- Reconozco mis emociones y puedo manifestarlas con facilidad. (22 respuestas)

- No me identifico con ninguna (0 respuestas)

10. ¿Algún ser querido, conocido o persona de tu entorno se ha contagiado o ha fallecido por COVID-19?

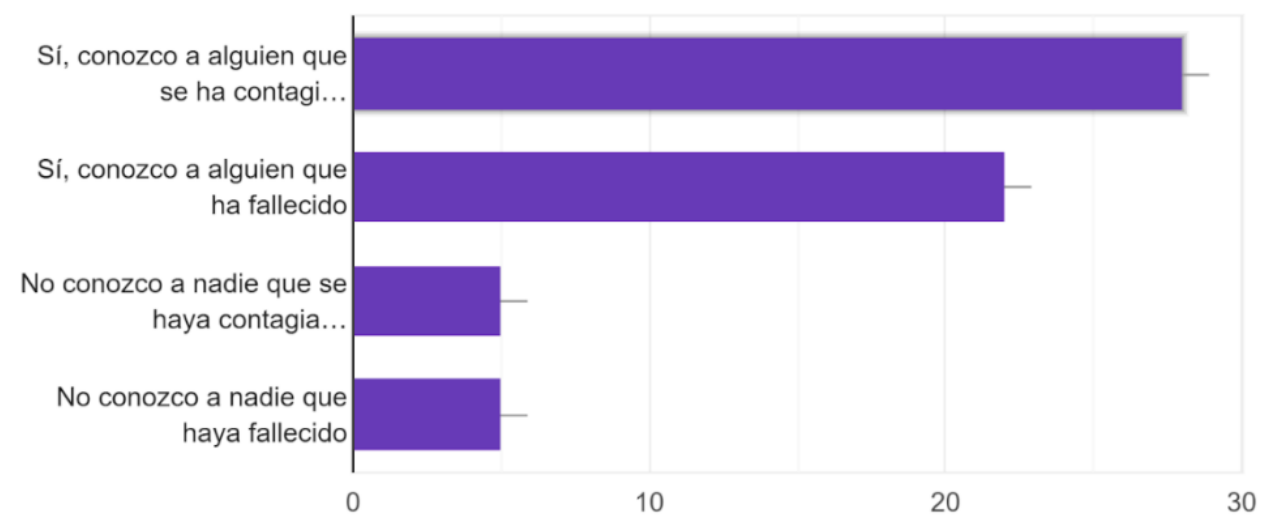

\section{Si marcaste que sí a alguno de los casos anteriores ¿Podrías contar} brevemente a quién le pasó, qué sucedió y si causó algún impacto en ti?

- Mi cuñado, ex compañeros de trabajo, y algunos otros conocidos del barrio. Me puso triste porque no debieron morir así y no pude despedirme de ninguno.

- Mi papá salió positivo al COVID le chocó con la presión alta y bajó a saturar hasta 88 y me asuste porque no quiero perder a mi padre, lo amo mucho.

- Una vecina tuvo problemas con su salud y guardando reposo en un hospital de la capital, fue ahí donde se contagió y se quedó para no salir, falleció. Un vecino que tiene su movilidad personal de igual manera, y 1 familiar que cuidaba a su propia familia y lastimosamente fallecieron, fueron 3 personas de una misma familia, y familias lejanas... que no sabían que tenían la enfermedad y fallecieron por los problemas respiratorios. La verdad que sí este tema en particular de la enfermedad, 
me chocó mucho, es una pena lamentable a pesar que existen normas para cumplirlas la propia gente no hace caso y es muy triste.

- Un primo falleció de COVID al parecer fue contagiado el impacto que me produjo es que como a cualquiera le duele la pérdida de un familiar y a tomar medidas preventivas más que nunca.

- A mi hermana, me afectó emocionalmente pero lo supere pronto

- A mis hermanos, estaba muy preocupado

- Falleció mi tío y uno de mis amigos, se fueron en días. Fue bastante duro.

- El esposo de mi prima falleció y pensé que sí podía salvarse porque estaba mejorando pero murió y dejó 4 hijos y a mi prima...me impactó lo súbito y la tristeza de mi prima.

- A una persona que hacía transporte público. Me impactó porque era muy joven y se le veía saludable .

- Mi hija se contagió pero por la atención inmediata no se complicó.

- El tío de mi esposa falleció de COVID-19.

- Era solo un conocido, sentí mucha pena.

- Falleció con COVID-19 y nos dejó un vacío en la familia.

- Familiares, hermanos y amigos me choco. Estuve preocupado porque no les pase algo sin poder dormir en varias noches

- Un compañero de colegio. Tenía mi edad y eso me puso susceptible. Nos hace entender lo frágiles que somos ante esta pandemia.

- Compañeros de trabajo fallecieron por el virus

- Un tío que sufría de diabetes murió al ser contagiado.

- Salía a trabajar y en el transporte público adquirió el virus.

- Mi hermana se contagió y colegas jóvenes de trabajo fallecieron. 
- Al frente de la casa de mi mamá se murió el esposo de una vecina. Y una compañera de estudio de manualidades estuvo con los síntomas pero vive lejos me dijo por teléfono.

- Les sucedió a muchos tíos, y lo que me impactó fue la falta de humanidad en la atención médica y de emergencia de muchas clínicas y hospitales, incluso el trato que recibe la persona fallecida de COVID.

- Mi esposo

- A un familiar lejano pero su partida fue muy dolorosa porque no esperaba este desenlace tan pronto.

- A un amigo de mi promoción. El está mucho mejor

- Falleció un tío muy cercano, suponemos que se contagió no lo supimos y de pronto sin poder ayudarlo falleció de una manera muy triste y solo, el impacto fue terrible ya que poco antes que falleciera converse con él y estuvo bien se sentía bien de pronto te enteras que ya no está es muy fuerte la noticia deprimente .

- A muchos compañeros de trabajo, me dio mucha pena

- Un tío materno se contagió y después de una semana batallando contra la enfermedad falleció. Me hizo dar cuenta que a cualquiera le puede llegar la muerte y que tenía que cuidarme más para así poder proteger a mi familia.

- Pena y tristeza.

- No era muy cercano.

- Varios vecinos, y familiares lejanos, por desgracia se contagiaron y fallecieron. Mucha pena y miedo por mi familia.

- Muchas personas que conocía fallecieron, entre ellas tíos, amigos o conocidos míos y de mis hijas. Mucha tristeza porque en muchos casos las muertes fueron muy tristes.

- Mi primo se contagió y luego nos contagió a todos. 
12. ¿Has tenido alguno de estos pensamientos durante la pandemia? Marca todos aquellos que hayas tenido

- Siento que nada volverá a ser como antes (32 respuestas)

- Siento que necesito la compañía de gente que ahora no tengo cerca (9 respuestas)

- Siento que ya no soy la persona que era antes (6 respuestas)

- Tengo miedo a la muerte (propia o de mis seres queridos) (17 respuestas)

- Me siento estresado y ansioso (17 respuestas)

- Me he vuelto muy pesimista (4 respuestas)

- Me siento triste y deprimido (5 respuestas)

- Tengo problemas para dormir (16 respuestas)

- Ninguno de los anteriores (4 respuestas)

OTROS:

- Necesidad de ir a misa y comulgar (1 respuestas)

- Me da miedo salir y enfermarme ( 2 respuestas)

- No me siento mal porque hago mis manualidades y he dejado de ver noticias cuando estoy sola y lo vemos cuando vienen de trabajar. (1 respuesta)

- Estresado de repente pero no ansioso (1 respuesta)

13. Si alguna persona muy cercana a ti falleciera a causa del COVID-19 ¿Cuál sería el factor más angustiante para ti?

- No poder realizar un velorio en su honor ( 2 respuestas)

- No poder acompañarlo en sus últimos momentos de vida (25 respuestas)

- No poder asistir a su entierro (1 respuesta)

- Tener que lidiar con trámites engorrosos o deudas (1 respuesta)

- Tener miedo a que yo u otra persona en casa se contagie (10 respuestas) OTROS

- No poder hacer nada para salvarla o salvarlo (1 respuestas)

- Que no pueda recibir los sacramentos (1 respuestas) 
Anexo 2

\section{Entrevista 1}

- Nombre: Tatiana Dunezat

- Cargo: Psicóloga

- Fecha: 16 de Septiembre

\section{Desarrollo:}

\section{1. ¿Cuál es la diferencia entre el duelo normal y el duelo patológico?¿Cuáles son} sus consecuencias?

Cada persona experimenta el proceso de duelo de distinta manera, definitivamente, el sufrimiento que le ocasiona a la persona es un tema psicológico, que deriva de una serie de síntomas, como puede ser el miedo y la tristeza profunda. Cuando hay un duelo patológico esa tristeza profunda se puede convertir en una depresión, pero hay variedad de síntomas. Hay varias fases en el duelo. La primera es la negación. Dependiendo de la causa de muerte, cuando es una enfermedad que es crónica, donde el ser querido se va apagando lentamente, como puede ser un cáncer o una enfermedad larga, ya la persona va procesando el duelo anticipadamente, antes de la muerte, pero va a depender de la causa de muerte, entonces cuando son accidentes, cuando es una muerte de golpe, como puede ser el caso del COVID, hay mucha gente que estoy atendiendo que no se lo espera, pues esa fase de negación puede durar un poco más que en una persona que ya está viendo venir la muerte de un familiar y lo va procesando de otra manera, porque el ver sufrir a la persona, lo que muchas veces quieren es que se vayan porque no lo quieren ver sufrir entonces el proceso de duelo es mucho más rápido por así decirlo, pero acá va a implicar muchas cosas, como te digo , va a implicar los recursos de la persona, su estabilidad emocional, el apoyo emocional que tengan, el pedir ayuda porque hay gente que no pide ayuda, como te digo hay una etapa, la primera etapa la negación donde la gente no lo puede creer, lo niega, viene mucho enfado, la cólera, un tema de creencia de injusticia, luego viene una etapa que es de negociación, donde empiezan a tener pensamientos un poquito irracionales, "pero 
porque me paso esto", empiezan a tener una fase de asimilación por así decirlo y luego viene la fase de aceptación donde aceptan la muerte y también el concepto que cada uno tiene de la muerte.

\section{2. ¿Las creencias, tradiciones y costumbres fúnebres influyen en el proceso de} duelo?

Cada uno tiene conductas o emociones de acuerdo con las creencias que tiene de base, tú eres Mailing porque tienes un sistema de creencias, yo tengo un sistema de creencias y este puede ser irracional o no. Ese sistema de creencias va a hacer que yo pueda sufrir mucho o que yo atraviese un duelo de una manera mucho más adaptativa. Yo siempre les digo a mis pacientes, el sufrimiento es parte de la vida, desde que nacemos sabemos que vamos a morir en algún momento y sabemos, por ley de vida, que nuestros padres van a fallecer en algún momento, pero hay gente que no lo ve así, y te dicen: "Me muero si mi mama fallece", "Me muero si pasa esto".

\section{3. ¿Qué otros factores podrían complicar el duelo?}

La dependencia emocional también es un factor importante, si tú eres dependiente emocionalmente va a ser mucho más difícil y mucho más probable que tengas un duelo patológico. El tener una vida individual propia es un factor importante para tener un proceso de duelo normal, porque lo normal es que yo me sienta triste, que pueda llorar, tener una serie de síntomas como puede ser insomnio, presión el pecho, ansiedad, el miedo al mañana, el miedo a que va a pasar ahora con mis hijos, esas ideas. Piensan por qué la vida le hizo esto, culpa a dios, culpa a todo el mundo, ese tipo de creencia la bloquea, la incapacita, la inhabilita.

Cuando la dependencia emocional es exagerada, es mucho más duradero, los síntomas son más intensos y puede venir el duelo patológico, entonces hay factores que un psicólogo puede percibir. Si soy dependiente emocionalmente, si no tengo una vida individual propia, si no tengo esos factores de protección que me ayudan a salir adelante, el tener resiliencia. La dependencia emocional no solo es de la pareja, puede ser de los padres, de 
los tíos, de los amigos, de la pareja, yo creo que esto es lo más resaltante que te podría decir.

\section{4. ¿Qué tipo de tratamiento se les da a las personas que sufren de duelo} patológico?

Yo siempre digo que trabajar la autonomía, todos los recursos que puede tener una persona, como pueden ser los amigos, el apoyo de estas relaciones afectivas saludables es muy importante. El tener una vida individual en la cual tú te sientas a gusto, tus trabajos, tus estudios, el sentirte realizado va a hacer que sea un escudo frente a todo ese problema del duelo, la muerte, el concepto que yo tengo de la muerte va a depender de si yo tengo realmente un duelo patológico. Por lo tanto el tener una filosofía de vida, y una vida individual rica, es decir, que yo me sienta cómodo va a ser determinante para yo salir adelante, frente a una situación dolorosa que vamos a vivir mucho y, por otro lado, es la creencia de base que realmente tenemos sobre la muerte. Si yo considero la muerte como algo que no puedo controlar pero lo acepto, es parte de la vida, lo voy a procesar de una manera diferente a cuando yo no acepto la muerte, entonces hay varios puntos que tocar, es muy profundo y varia de persona en persona.

\section{5. ¿Cuál es la mejor ayuda que se le puede dar a una persona para que pueda resolver su duelo satisfactoriamente?}

Como te digo va a influir lo que uno cree. En este caso cuando uno pide ayuda y te das cuenta de que el dolor esta porque no se pudo despedir porque ya está acostumbrada a tener un velorio, por pasar por una serie de procesos en esta despedida, lo que sugiero y trabajo con la gente que ha recurrido a mí con el tema del duelo que han perdido un familiar y no han podido despedirse trabajo mucho el que hagan ritual a solas, que hagan el ritual no con la persona, no necesitan a la persona, cambiarle el estilo de creencia, y hacerle entender que la despedida puede ser de mil maneras, han hecho un pequeño ritual en un jardín de su casa, han puesto la foto del ser querido, han orado, han rezado. Las creencias religiosas influyen. De repente hacemos un pequeño espacio en casa, donde se 
unan familiares, hacerles ver que el cuerpo es polvo, que el alma y el espíritu están ahí. Hay que trabajar la aceptación en esta situación en la que no nos podemos despedir de manera común, alivia muchísimo el hacer esto desde casa, desde un ambiente en el cual yo pueda rezar. Conozco dos casos en los que han enterrado la fotito como si fuera la persona y han hecho un pequeño altarcito. Hay varias cosas que se pueden hacer y ahí se desahogan.

Yo creo que el primer paso para uno aliviar sus emociones es el expresar lo que sientes, muchas veces se expresan a través de la narrativa, a través de la escritura. La terapia a través de la narrativa ayuda mucho cuando a la persona le cuesta expresarse, el permitirse dejarse llevar por las emociones, de expresarte a través del llanto, con cualquier herramienta que pueda surgir, pero eso es lo que he estado trabajando y ha funcionado y hay que hacerle ver que hay mil formas de poder despedirse de esta persona.

\section{6. ¿Cuál es la diferencia entre depresión y duelo?}

Diferenciemos la tristeza versus depresión, porque la tristeza es una emoción natural, funcional y lógica en el proceso de duelo. Lo anormal seria que yo me sienta feliz, que tenga emociones agradables. Nosotros los seres humanos tenemos un abanico de emociones tanto agradables y desagradables, vamos a vivir todas, pues se presentan emociones normales en el proceso de duelo, sin embargo, en el caso de la depresión no .

\section{7. ¿Cuál es el tipo de comunicación que se debe manejar con una persona en duelo?}

Ahí hay un gran error, te dicen quédate tranquila, y esas frases que normalmente hacen que la persona se inhiba más, que el mismo sienta que no tiene que ser fuerte. Este es un proceso sonde se debe permitir, tener esas emociones, llorar, escribir cuando quieras, ver las fotos, todo momento en el que sientas la necesitad, hazlo. Una cosa es que te digan que los procesos de duelo son así, pero a todos no les ocurre lo mismo. Cada ser humano es único, desde la terapia uno va percibiendo como la persona expresa sus emociones; por ejemplo puede que al primer mes no está llorando pero que el quinto mes se quiebre por 
haber tratado de ser fuerte y de seguir con su vida. Es importante darles la oportunidad de sentir, de permitirse llorar, de permitirse estar mal de vez en cuando, porque esta sociedad nos ha enseñado que debemos ser felices en todo momento y eso es una falacia, no es que hemos venido a ser felices siempre, a veces ocurren cosas tristes y se nos debe permitir estar mal sabiendo de que no va a pasar nada y que en el futuro nos ira muchísimo mejor.

\section{Anexo 3}

\section{Entrevista 2}

- Nombre: Tatiana Dunezat

- Cargo: Psicóloga

- Fecha: 30 de septiembre

\section{Desarrollo:}

\section{1. ¿Por qué es importante desarrollar un duelo sano?}

Cuando una persona no está presente, tienes que ser consciente de que te vas a quedar con lo que te suma y no con lo que te resta, lo vas a extrañar siempre, lo importante es que tu vida pueda continuar, y tu vida va a continuar siempre y cuando hayas podido liberar todo ese dolor que tienes.

Cuando llegas a la etapa final de aceptación, ya no recuerdas con dolor (De lo contrario estarías entrando a un duelo patológico). Hay gente que habla de un ser querido que falleció y hablan con alegría, porque son conscientes de lo bonito que fue haber tenido a esa persona, hablarlo ayuda muchísimo en terapia y verlo desde otra perspectiva, no del dolor sino de la perspectiva de suerte que tuve un conyugue así, tu vida continua con otro tipo de persona y creo que eso es lo importante.

\section{2. ¿Cómo recomienda realizar la elaboración del rito de despedida?}

Durante la pandemia no te puedes despedir adecuadamente. Obviamente parte del proceso del duelo, de la sanación y aceptación es la despedida. Hay mucho sentimiento de culpa cuando no se brinda esa despedida de una manera adecuada. El funeral es un tipo de ritual, el velorio es un tipo de ritual, entonces por eso te comenté la importancia de crear un ritual 
con la familia o a través de una carta o a través de una fotografía para realmente palear un poquito esos sentimientos de culpabilidad, o de tristeza profunda

\section{3. ¿Cómo estimulan las fotografías al doliente?}

Va a depender de la fase donde se encuentre el proceso del duelo pero varia de persona en persona. Hay gente que quiere evitar a toda costa ver una fotografía del ser querido, o ver algún objeto o eliminar todas las cosas. Cuando evitamos nuestras emociones, tanto el miedo como la tristeza, pueden aumentar. En la etapa de aceptación es donde la persona es consciente de que esta persona no va a regresar, pero si es importante visualizar y expresar sus sentimientos.

El permitirse llorar, estar triste, liberarse y como te decía la vez pasada, a veces la felicidad está sobrevalorada y parece que todo son mensajes optimistas y que todo el mundo tiene que estar feliz en todo momento y eso no es cierto, la persona tiene que darse cuenta que hay etapas en la vida donde el sufrimiento es parte de ella y hay esas etapas en donde tenemos que llorar, estar tristes y el evitarlo hace que esto aumente, precisamente te decía el tema de la foto porque realmente nos ayuda a liberar. El funeral por ejemplo. En los velorios hay mucha gente a la que le gusta acercarse para despedirse, le gusta ver a la persona que falleció; sin embargo, hay otras que no, entonces es importante que cada uno pueda expresar, de repente no con la foto, de repente con algo que la haga sentir más cómoda.

\section{4. ¿Cuánto ayuda redactar cartas durante el duelo?}

La comunicación intrapersonal es sumamente importante, si nos decimos, estoy triste, no puedo vivir sin esta persona, al tenerlo por escrito podemos analizar y liberar estos sentimientos. La narrativa ayuda mucho ya que nos ayuda a despedirnos de esta emoción que no nos deja hacer nuestra vida. Yo recomiendo hacer una carta de despedida, pero de despedida a ese dolor, a esa emoción que no puedes sacar, me despido y yo tomo el rumbo de mi vida. 
En el proceso de duelo con las cartas, el verbalizar contigo mismo a través de la narrativa y decir, a partir de hoy me despido de esta depresión o esta ansiedad porque en el duelo ocurren muchas emociones, hay ansiedad por el miedo a pasar por algo similar mas adelante, a sentirte sola, constantemente estamos anticipando el futuro, una situación similar. Entonces lo importante de la carta es que yo me despido y yo mismo escribo: "Querida tristeza o depresión, a partir de hoy voy a tomar el rumbo de mi vida, y no voy a permitir que me anules como persona, que me bloquees, que no me permitas hacer mis actividades cotidianas ni ser feliz".

Ese lenguaje interno me ayuda contra la tristeza, el tenerlo por escrito me da control porque depende de uno salir de esa situación, por eso lo de la carta también puedes despedirte de la persona que se fue, de alguna manera decirle lo importante que era para ti. Durante la pandemia no hay estos rituales, hay personas que le dejan una flor o una carta, va a depender de cuanto la persona es capaz de expresarse, realmente la carta le ayuda mucho más a las personas que les cuestan expresarse, entonces lo pueden expresar a través de la escritura, eso va a depender de la personalidad y de otros factores.

\section{5. ¿Cómo debemos dirigirnos a estas personas?}

Yo creo que las cosas, por más tristes que sean, no hay que maquillarlas tanto. La psicología es importante, tengas la edad que tengas, obviamente a un niño de tres años se le tiene que decir con diferentes palabras que a un niño de siete, necesitas buscar las palabras pero siempre con la verdad, decirle mira, papá se ha ido al cielo, mamita esta con Dios, hacerle ver que realmente ha fallecido. Con una persona adulta no tendría nada de malo, en la comunicación no verbal, no importa que termino utilices sino el cómo lo dices, el tono de voz que utilizas cuando transmites algunas cosas, ante esa noticia va a haber dolor pero lastimosamente se tiene que decir así.

El cómo lo decimos a través de nuestros gestos mostrando empatía, que sientas su dolor, yo creo que eso es mucho mas importante y luego el apoyo emocional que uno brinde. 
Anexo 4

Lima 17 de noviembre 2020

Señores,

Carrera de Arte y Diseño Empresarial

Facultad de Humanidades

Universidad San Ignacio de Loyola

Por medio de la presente me dirijo a ustedes a fin de poder dar una opinión objetiva respecto al proyecto "Abrazo en caja" diseñado por la Bachiller Mailing Chang Huancaya referido al diseño de un producto que contiene herramientas que ayudan a los familiares de las víctimas del COVID-19 a vivir un duelo sano y poder resolverlo evitando que este se torne patológico.

Por lo tanto, al analizar y revisar el proyecto minuciosamente encuentro que el mismo es importante, pertinente e innovador pues apoya a las familias que tuvieron una pérdida de algún familiar en época de pandemia, brindándoles un novedoso modo de despedida a los mismos y que previene el deterioro de la salud mental de los afectados con herramientas biodegradables y motivadoras. Este proyecto facilita el duelo de modo responsable ante una situación de pandemia y es seguro para el uso de toda la familia.

Atentamente

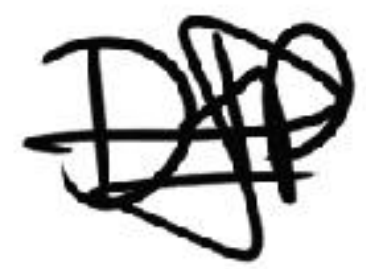

Lic. Danitza Tello Paredes 
Anexo 5

Lima 16 de noviembre 2020

Señores,

Carrera de Arte y Diseño Empresarial

Facultad de Humanidades

Universidad San Ignacio de Loyola

Por medio de la presente me dirijo a ustedes a fin de poder dar una opinión objetiva respecto al proyecto "Abrazo en caja" diseñado por la Bachiller Mailing Chang Huancaya referido al diseño de un producto que contiene herramientas que ayudan a los familiares de las víctimas del COVID-19 a vivir un duelo sano y poder resolverlo evitando que este se torne patológico.

Por lo tanto, al analizar y revisar el proyecto minuciosamente encuentro que el mismo sí logra ser una herramienta creativa que puede ayudar a las personas que no han podido tener una despedida física con sus seres queridos fallecidos; ya que es un tipo de "obsequio" en caja que contiene no sólo los objetos explicados; sino que también tiene la posibilidad de que las personas lo personalicen y agreguen lo que deseen. El personaje creado humaniza la marca, además las frases y patrones creados para las distintas piezas gráficas ayudan a la reflexión y le dan ese apoyo a la persona que tiene sentimientos reprimidos, ya que son objetos que pueden utilizar en el momento que quieran.

Los colores son otro punto a favor, pues han logrado armonizar de manera sutil por ser análogos; haciendo que esos mismos colores cálidos refuerzan el concepto de calidez humana.

Los materiales implementados también son de gran ayuda para que tanto la persona que compre como la que reciba el regalo sean conscientes de que no sólo está apoyando a un ser querido, sino también al medio ambiente y esa es otra manera de poder ofrecer este producto.

Creo que el proyecto tiene potencial para salir al mercado de la mano de una campaña que comunique ese "apoyo" a su público objetivo y logre crear un vínculo con la marca.

Atentamente

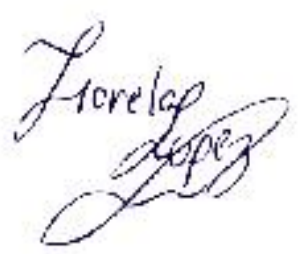

Lic. Fiorela Martha López Alcocer

Dirección y Diseño Publicitario 
Anexo 6

Lima 21 de noviembre 2020

Señores,

Carrera de Arte y Diseño Empresarial

Facultad de Humanidades

Universidad San Ignacio de Loyola

Por medio de la presente me dirijo a ustedes a fin de poder dar una opinión objetiva respecto al proyecto "Abrazo en caja" diseñado por la Bachiller Mailing Chang Huancaya referido al diseño de un producto que contiene herramientas que ayudan a los familiares de las víctimas del COVID-19 a vivir un duelo sano y poder resolverlo evitando que este se torne patológico.

Por lo tanto, al analizar y revisar minuciosamente el referido proyecto, debo señalar que es una excelente opción de quemar una etapa en la vida de la persona que ha perdido a su ser querido por esta pandemia, además permite favorecer su salud mental y mediante el subjetivo abrazo se está proponiendo el incremento de las hormonas de la felicidad, tornándose emociones positivas que permitirán favorecer reacciones positivas en la persona por ende contribuir a su felicidad.

Atentamente

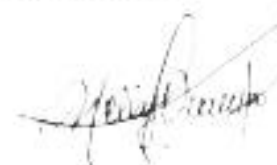

Lic. Nelly Ocampo Carhuas

Colegiatura $\mathrm{N}^{\circ} 37692$ 
Anexo 7

Lima 20 de noviembre 2020

Señores,

Carrera de Arte y Diseño Empresarial

Facultad de Humanidades

Universidad San Ignacio de Loyola

Por medio de la presente me dirijo a ustedes a fin de poder dar una opinión objetiva respecto al proyecto "Abrazo en caja" diseñado por la Bachiller Mailing Chang Huancaya referido al diseño de un producto que contiene herramientas que ayudan a los familiares de las victimas del COVID-19 a vivir un duelo sano y poder resolverlo evitando que este se torne patológico.

Por lo tanto, al analizar y revisar el proyecto minuciosamente encuentro que el mismo es importante, innovador sobretodo porque brinda un soporte emocional muy grande a todas aquellas personas o familias enteras que debido a esta pandemia por la que atravesamos no han logrado permanecer con su familiar durante el proceso de la enfermedad como usualmente se daba y por el contrario, los han perdido sin ningún chance de poder verlos, estar a su lado en sus últimos momentos o brindarles un último adiós.

Es un producto que nos brinda calma, paz, tranquilidad debido a las tonalidades que se han utilizado en el diseño de las piezas y nos inspira a aflorar todo aquello que no podemos expresar libremente ante otras personas; ya que no todas tenemos un mismo temperamento.

Para mi es una manera distinta de expresar y compartir mi sentimiento y apoyo hacia esa otra persona a quien quizá sé que con las palabras comunes de condolencia no tendría el mismo impacto que realizarlo de esta manera; ya que, en mi caso, pienso que nadie sentirá el verdadero dolor por el que atraviesan.

Es una bonita forma de expresar, muy sutil, muy cariñosa y más sincera que tan solo unas palabras.

Atentamente

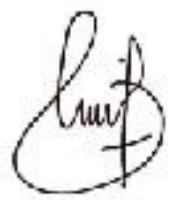

Lic. Merry Melina Paredes Huancaya 
Anexo 8

Lima 16 de noviembre 2020

Señores,

Carrera de Arte y Diseño Empresarial

Facultad de Humanidades

Universidad San Ignacio de Loyola

Por medio de la presente me dirijo a ustedes a fin de poder dar una opinión objetiva respecto al proyecto "Abrazo en caja" diseñado por la Bachiller Mailing Chang Huancaya referido al diseño de un producto que contiene herramientas que ayudan a los familiares de las víctimas del COVID-19 a vivir un duelo sano y poder resolverlo evitando que este se torne patológico.

Por lo tanto, al analizar y revisar el proyecto minuciosamente encuentro que el mismo es muy novedoso, importante, con mucha carga social, que permitirá ayudar psicológicamente a las personas a superar posibles traumas con secuelas personales muy importantes, además busca despertar conciencia en la población en cuanto a lo ecológico. Busca solución a este problema familiar.

Atentamente

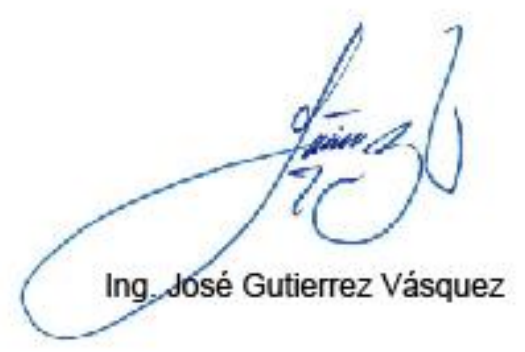

